UNIVERSIDADE FEDERAL DE JUIZ DE FORA

ENGENHARIA ELÉTRICA

PROGRAMA DE PÓS GRADUAÇÃO EM ENGENHARIA ELÉTRICA

Fabiane Barbosa do Nascimento

Estratégias de Predição de Preços do Mercado Livre de Energia por Redes Neurais Artificiais e Filtragem Estocástica

Juiz de Fora 
Fabiane Barbosa do Nascimento

Estratégias de Predição de Preços do Mercado Livre de Energia por Redes Neurais Artificiais e Filtragem Estocástica

Dissertação de Mestrado apresentada ao Programa de Pós-Graduação em Engenharia Elétrica, da Faculdade de Engenharia da Universidade Federal de Juiz de Fora, como requisito para a obtenção do título de Mestre em Engenharia Elétrica.

Orientador: Prof. Dr. Leonardo Willer de Oliveira

Coorientador: Prof. Dr. Ivo Chaves da Silva Junior

Juiz de Fora 
Fabiane Barbosa do Nascimento

\title{
Estratégias de Predição de Preços do Mercado Livre de Energia por Redes Neurais Artificiais e Filtragem Estocástica
}

\begin{abstract}
Dissertação de Mestrado apresentada ao Programa de Pós-Graduação em Engenharia Elétrica, da Faculdade de Engenharia da Universidade Federal de Juiz de Fora, como requisito para a obtenção do título de Mestre em Engenharia Elétrica.
\end{abstract}

Aprovada em 27 de Abril de 2021.

\section{BANCA EXAMINADORA}

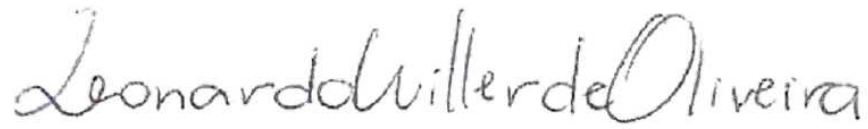

Prof. Dr. Leonardo Willer de Oliveira - Orientador Universidade Federal de Juiz de Fora

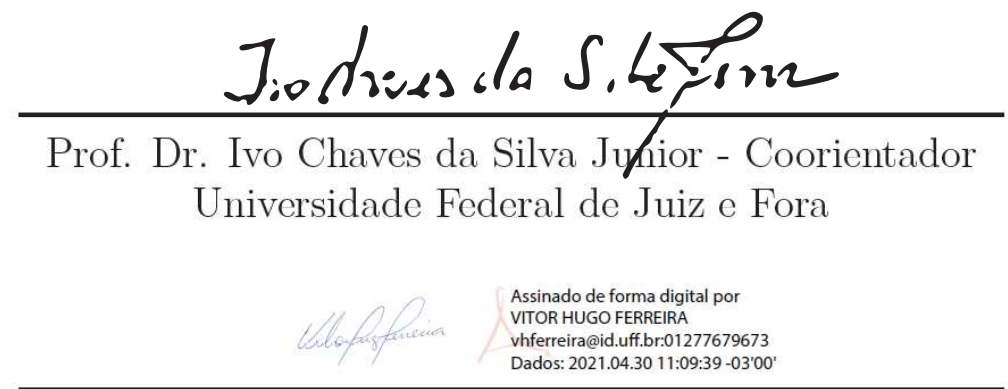

Prof. Dr. Vitor Hugo Ferreira - 1 ${ }^{\mathrm{o}}$ Titular Externo Universidade Federal Fluminense

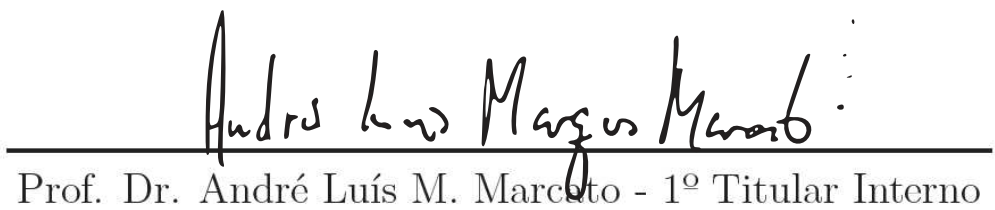
Universidade Federal de Juiz e Fora

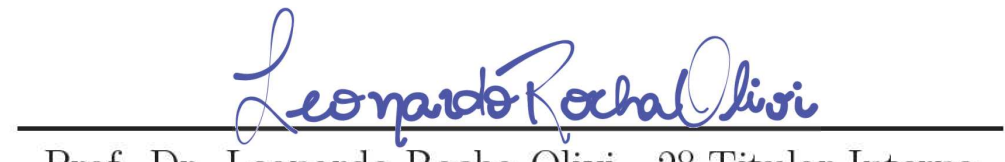

Prof. Dr. Leonardo Rocha Olivi - 20 Titular Interno Universidade Federal de Juiz e Fora 


\section{AGRADECIMENTOS}

Agradeço primeiramente a Deus, por jamais me deixar nas horas difíceis e por ter planos para a minha vida que são sempre maiores do que os meus sonhos.

À minha família, pelas palavras de incentivo, por sempre acreditarem em mim e sonharem junto comigo.

Ao professor Leonardo Rocha Olivi, pela grande e positiva influência que efetivamente exerceu em minha vida pessoal e profissional. Pelo apoio incondicional, por sempre estar disposto a me ensinar e ajudar.

Agradeço aos professores orientadores Leonardo Willer de Oliveira e Ivo Chaves da Silva Júnior pela oportunidade, confiança, paciência e apoio oferecido no desenvolvimento desta Dissertação.

Agradeço também, a disponibilidade dos membros da banca por fazerem parte desse momento trazendo contribuições para a melhoria do trabalho desenvolvido.

Agradeço à Denise por permitir que eu iniciasse este sonho, me liberando para a realização das atividades, além do incentivo e apoio constantes dados em minha carreira.

À Universidade Federal de Juiz de Fora e ao Programa de Pós-Graduação de Engenharia Elétrica pelo apoio a este trabalho.

E a todas as outras pessoas que, das mais diferentes maneiras, participaram desta história. 
"A persistência é o menor caminho para o êxito." Charles Chaplin 


\section{RESUMO}

O Preço de Liquidação das Diferenças (PLD) é utilizado como base na comercialização de energia elétrica no mercado de curto prazo. O conhecimento dos seus valores futuros e tendências reduz a insegurança na tomada de decisões, permitindo que os agentes de mercado decidam as estratégias mais adequadas e estabeleçam contratações bem-sucedidas, maximizando os lucros e minimizando os riscos de seus empreendimentos. O PLD é, no entanto, influenciado por diversos fatores ligados principalmente às incertezas das demandas e à hidrologia bem como fatores sociais e políticos, o que lhe confere alta volatilidade, sazonalidade, saturação de valores e comportamento estocástico. Desta forma, o presente trabalho propõe uma abordagem investigativa para a predição das tendências futuras do PLD por meio de Redes Neurais Artificiais e Filtragem Estocástica, com a motivação de auxiliar o processo de decisão da compra de energia no mercado de curto prazo. Tal abordagem consiste na combinação de uma rede neural do tipo recorrente com um filtro na saída para atenuar os ruídos inerentes aos dados auxiliando na preservação das tendências dos dados futuros. A rede foi treinada por meio do algoritmo $A D A M \mathrm{e}$ é aplicada ao mercado brasileiro de energia. A escolha dos dados de entrada da rede foi feita a partir de análises estatísticas de correlação cruzada entre as séries temporais das variáveis de interesse. Os resultados mostram uma boa capacidade de predição com um bom acompanhamento das tendências da variável de interesse ao longo do ano, oferecendo seus principais comportamentos e tendências aos operadores de mercado, auxiliando-os nas tomadas de decisões de compra e venda de energia.

Palavras-chave: Preço de Liquidação das Diferenças, Modelos de Predição, Predição de séries Temporais, Redes Neurais Artificiais, Filtragem Estocástica. 


\begin{abstract}
The Settlement Price of Differences (PLD) is used as a basis for the sale of electrical energy in the short-term market. The knowledge of its future values and trends mitigates insecurity in decision making, allowing market agents to decide the most appropriate strategies and establish successful contracts, maximizing profits and minimizing the risks of their ventures. PLD is, however, influenced by several factors linked mainly to the uncertainties of demands and hydrology as well as social and political factors, which gives it high volatility, seasonality, saturation of values and stochastic behavior. In this way, the present work proposes an investigative approach for the prediction of future trends of PLD through Artificial Neural Networks and Stochastic Filtration, with the motivation to assist the decision process of purchasing energy in the short-term market. Such an approach consists of combining a recurrent neural network with an output filter to attenuate the noise inherent in the data, helping to preserve future data trends. The network was trained using the ADAM algorithm and is applied to the Brazilian energy market. The choice of network input data was made based on statistical analyzes of cross-correlation between the time series of the variables of interest. The results show a good predictive capacity with a good monitoring of the trends of the variable of interest throughout the year, offering its main behaviors and trends to market operators, assisting them in making energy purchase and sale decisions.
\end{abstract}

Keywords: Settlement Price of Differences, Forecasting Models, Time Series Forecasting, Artificial Neural Networks, Stochastic Filtering. 


\section{LISTA DE ILUSTRAÇÕES}

Figura 1.1 - Comparação CMO e PLD . . . . . . . . . . . . . . . . . . 15

Figura 2.1 - Estrutura do Setor Elétrico Brasileiro. . . . . . . . . . . . . . . . . 21

Figura 2.2 - Cronograma de decisão para um sistema hidrotérmico. . . . . . . . . . 23

Figura 2.3 - Regiões do Sistema Interligado Nacional. . . . . . . . . . . . . . . . . 24

Figura 2.4 - Topologia de rede recorrente. . . . . . . . . . . . . . . . . . 28

Figura 3.1 - PLD médio de todos os submercados. . . . . . . . . . . . . . . . 37

Figura 3.2 - Rede com filtragem antes da realimentação. . . . . . . . . . . . . . . . 39

Figura 3.3 - Convergência dos algoritmos de treinamento. . . . . . . . . . . . . . . . 40

Figura 3.4 - Seno contaminado por ruído aleatório Gaussiano. . . . . . . . . . . . . 41

Figura 3.5 - Exponencial negativa multiplicada por seno. . . . . . . . . . . . . . . 42

Figura 3.6 - Composição de senoides de diferentes frequências. . . . . . . . . . . . . 42

Figura 3.7 - Séries de dados da ONS e suas unidades: CE [MWmed], DM [MWh/h], EA [MWmês], ENA [MWmed], GE [MWmed] e IE [MWmed]. . . . . . 43

Figura 3.8 - Série de dados - CMO e PLD . . . . . . . . . . . . . . . . . . . 44

Figura 3.9 - Função ReLU e sua derivada. . . . . . . . . . . . . . . . . . . . . . . . 45

Figura 4.1 - Predição para $N_{1}=N_{2}=20$ e $n_{p}=n_{q}=10 \ldots \ldots \ldots$. . . . . . . 51

Figura 4.2 - Predição para $N_{1}=N_{2}=20$ e $n_{p}=n_{q}=20 \ldots \ldots$. . . . . . . . . 51

Figura 4.3 - Predição para $N_{1}=10 N_{2}=20 \quad N_{3}=15$ e $n_{p}=n_{q}=10$. . . . . . . . . . . . 52

Figura 4.4 - Predição para $N_{1}=10 N_{2}=20 N_{3}=15$ e $n_{p}=n_{q}=20$. . . . . . . . . . . 52

Figura 4.5 - Treinamento e Predição para $N_{1}=N_{2}=N_{3}=50$ e $n_{p}=n_{q}=30$. . . . . . . 53

Figura 4.6 - Predição para $N_{1}=N_{2}=N_{3}=50$ e $n_{p}=n_{q}=30$. . . . . . . . . . . . 53

Figura 4.7 - Predição para $N_{1}=N_{2}=20$ e $n_{p}=n_{q}=2 \ldots \ldots \ldots$. . . . . . . 55

Figura 4.8 - Predição para $N_{1}=10, N_{2}=20, N_{3}=15$ e $n_{p}=n_{q}=2 \ldots \ldots$. . . . . . . 55

Figura 4.9 - Correlação cruzada do CMO para janelas de dados da série temporal, evidenciando a correlação entre dados da mesma série temporal em tempos diferentes. . . . . . . . . . . . . . . . 57

Figura 4.10-Correlação cruzada: esquerda) CMO e direita) ruído Gaussiano, evidenciando a baixa correlação do CMO para janelas em instantes de tempos distantes, de maneira similar a variável aleatória, que não uma possui alta intensidade de estruturas repetidas ou periódicas no longo prazo. . 57

Figura 4.11-Correlação das variáveis com o CMO para janelamentos de até 730 dados. 59

Figura 4.12-Correlação das variáveis com o CMO para janelamentos de até 30 dados. 59

Figura 4.13-Treinamento e Predição para $N_{1}=N_{2}=N_{3}=50$ e $n_{p}=n_{q}=20 \ldots$. . . . . 61

Figura 4.14-Predição para $N_{1}=N_{2}=N_{3}=50$ e $n_{p}=n_{q}=20 \ldots \ldots \ldots$. . . . . . . 62

Figura 4.15-Predição para $N_{1}=N_{2}=20$ e $n_{p}=n_{q}=20 \ldots \ldots$. . . . . . . . . 62

Figura 4.16-Treinamento e Predição para $N_{1}=N_{2}=N_{3}=50$ e $n_{p}=n_{q}=2 . \quad$. . . . . . 63 
Figura 4.17-Predição para $N_{1}=N_{2}=N_{3}=50$ e $n_{p}=n_{q}=10 \ldots \ldots$. . . . . . . . . 64

Figura 4.18-Predição para $N_{1}=N_{2}=N_{3}=50$ e $n_{p}=n_{q}=2 \ldots$. . . . . . . . . . . 66

Figura 4.19-Predição para $N_{1}=N_{2}=20$ e $n_{p}=n_{q}=10 \ldots \ldots$. . . . . . . . . 68 


\section{LISTA DE TABELAS}

Tabela 4.1 - Resultados por topologia - 1 passo no futuro . . . . . . . . . . . . 50

Tabela 4.2 - Resultados por topologia - vários passos no futuro ( $\mathrm{N}=53$ passos) . . . 54

Tabela 4.3 - Resultados por topologia (CE, DM, EA, GE, CMO e PLD) - vários passos no futuro $(1 \mathrm{ano}) \ldots \ldots . \ldots 60$

Tabela 4.4 - Resultados por topologia (CE, DM, EA, GE, IE, ENA, CMO e PLD) vários passos no futuro $(1 \mathrm{ano}) \ldots \ldots . . \ldots 63$

Tabela 4.5 - Comparação dos resultados utilizando ou não as variáveis IE e ENA . . 65

Tabela 4.6 - Resultados por topologia (CE, DM, EA, GE, IE, ENA, CMO e PLD) -

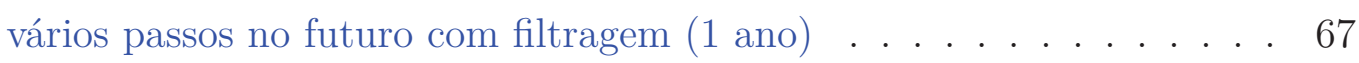




\section{LISTA DE ABREVIATURAS E SIGLAS}

ACL Ambiente de Contratação Livre

ACR Ambiente de Contratação Regulada

AdaGrad Adaptive Gradient Algorithm

ADAM Adaptive Moment Estimation

ANEEL Agência Nacional de Energia Elétrica

ARIMA Autoregressive integrated moving average

CCEE Câmara de Comercialização de Energia Elétrica

CE Carga de Energia

CMO Custo Marginal da Operação

CMSE Comitê de Monitoramento do Setor Elétrico

CNPE Conselho Nacional de Políticas Energéticas

DM Demanda Máxima

EA Energia Armazenada

ENA Energia Natural Afluente

EPE Empresa de Pesquisa Energética

FIR Finite Impulse Response

GE Geração de Energia

IE Intercâmbio de Energia

IGP-M Índice Geral de Preços Mercado

IIR Infinite Impulse Response

LMS Least Mean Square

MAE Mercado Atacadista de Energia Elétrica

MME Ministério de Minas e Energia

ONS Operador Nacional do Sistema

PLD Preço de Liquidação das Diferenças 
PCH Pequenas Centrais Hidrelétricas

RE-SEB Reestruturação do Setor Elétrico Brasileiro

ReLU Rectified Linear Unit

RMSE Root Mean Squared Error

RNA Rede Neural Artificial

TDNN Time Delay Network 


\section{LISTA DE SÍMBOLOS}

\begin{tabular}{|c|c|}
\hline$n_{p}$ & Amostras de entrada atrasadas \\
\hline$n_{q}$ & Amostras de saídas passadas realimentadas \\
\hline data $_{\text {norm }}$ & Função de treinamento normalizada \\
\hline $\max _{n o r m}$ & Valor máximo permitido para a normalização \\
\hline $\min _{\text {norm }}$ & Valor mínimo permitido para a normalização \\
\hline $\max _{d a t a}$ & Valor máximo permitido para a série temporal \\
\hline $\min _{\text {data }}$ & Valor mínimo permitido para a série temporal \\
\hline data & série temporal \\
\hline$m_{t}$ & Primeiro momento \\
\hline$v_{t}$ & Segundo momento \\
\hline$\beta_{1}$ & Taxa de aprendizado do primeiro momento \\
\hline$\beta_{2}$ & Taxa de aprendizado do segundo momento \\
\hline$g_{t}$ & Gradiente \\
\hline$\hat{m}_{t}$ & Primeiro momento corrigido \\
\hline$\hat{v}_{t}$ & Segundo momento corrigido \\
\hline$\Theta_{t}$ & Parâmetro de ajuste dos pesos \\
\hline$P_{i}$ & i-ésimo valor desejado pela rede \\
\hline$Q_{i}$ & i-ésimo valor obtido pela rede \\
\hline$N_{1}$ & Número de neurônios na primeira camada escondida \\
\hline$N_{2}$ & Número de neurônios na segunda camada escondida \\
\hline$N_{3}$ & Número de neurônios na terceira camada escondida \\
\hline . & Quantidade de amostras do conjunto \\
\hline
\end{tabular}




\section{SUMÁRIO}

INTRODUÇÃO .......................... 14

1.1 Objetivos e motivações . . . . . . . . . . . . . . . . 17

$1.2 \quad$ Produção Científica . . . . . . . . . . . . . . . . . 18

1.3 Estrutura da dissertação . . . . . . . . . . . . . . . 18

2 FUNDAMENTAÇÃO TEÓRICA . . . . . . . . . 19

$2.1 \quad$ O Setor Elétrico Brasileiro . . . . . . . . . . . . . . . . . . 19

2.2 A Formação do Preço de Liquidação das Diferenças . . . . . . . . . . . 21

2.3 Predição do PLD . . . . . . . . . . . . . . . . 24

$2.4 \quad$ Redes Neurais Artificiais . . . . . . . . . . . . . . . . 25

2.4.1 Redes Recorrentes . . . . . . . . . . . . . . . . 27

2.4.2 Métodos de Treinamento . . . . . . . . . . . . . 28

$2.5 \quad$ Filtragem . . . . . . . . . . . . . . . . . . 32

$2.5 .1 \quad$ Filtros Digitais . . . . . . . . . . . . . . . . 32

2.5.2 Filtro de Média Móvel . . . . . . . . . . . . . . . . . 33

2.5.3 Filtro de Kalman . . . . . . . . . . . . . . . . . 34

3 METODOLOGIA PROPOSTA ........... 37

$3.1 \quad$ Escolha dos Dados de Entrada . . . . . . . . . . . . . . 37

$3.2 \quad$ Escolha do Método de Treinamento . . . . . . . . . . . . . 39

$3.3 \quad$ Processamento das Variáveis . . . . . . . . . . . . . . . . . . 43

4 RESULTAdos E ANÁLISES . . . . . . . . . . . 48

$4.1 \quad$ CMO como única variável de entrada . . . . . . . . . . . . . . 49

4.1.1 Predição de um passo no futuro . . . . . . . . . . . . . . . . . . 49

4.1.2 Predição de vários passos no futuro . . . . . . . . . . . . . . . 54

4.2 Variáveis ONS como variáveis de entrada . . . . . . . . . . 58

$4.3 \quad$ Filtragem da saída da Rede Neural . . . . . . . . . . . . . . . 65

$4.4 \quad$ Conclusões sobre as análises dos resultados . . . . . . . . . . . . . . 68

$5 \quad$ CONCLUSÕES ....................... 70

$5.1 \quad$ Propostas de desenvolvimentos futuros . . . . . . . . . . . . . 71

REFERÊNCIAS ..................... 72 


\section{INTRODUÇÃO}

A energia elétrica é um bem considerado essencial e indispensável, e é por meio dela que se desenvolvem as principais atividades econômicas de qualquer país. O Brasil desenvolveu seu setor elétrico primariamente por meio de energia hidrelétrica, porém, também possui termelétricas, usinas eólicas e importação da energia de outros países. O setor elétrico brasileiro é estruturado de forma a garantir a segurança do suprimento de energia elétrica, promover a inserção social e a modicidade tarifária (CCEE, 2021f). Em referência aos mecanismos regulatórios e operacionais, este setor passou por diversas modificações ao longo dos anos.

O modelo setorial vigente é liberal e flexível, onde os consumidores livres e especiais podem escolher o fornecedor de energia. As relações comerciais se estabelecem em dois ambientes de contratação: o Ambiente de Contratação Regulado (ACR) e o Ambiente de Contratação Livre (ACL). No ACR, a energia é comprada pelas distribuidoras para os consumidores cativos via leilões e o preço é determinado pela Agência Nacional de Energia Elétrica (ANEEL). Já no ACL, as transações são feitas de forma bilateral entre os consumidores livres, geradores e comercializadores.

Há ainda o mercado de curto prazo, também conhecido como mercado de diferenças, onde se procede a contabilização e liquidação financeira das diferenças apuradas entre os montantes de energia elétrica contratados e verificados (gerados e consumidos) (ANEEL, 2021). Essas diferenças são valoradas por meio do Preço de Liquidação das Diferenças (PLD). A maneira como ele é calculado está intrinsecamente conectada com as características operativas do setor elétrico brasileiro, com seu parque de geração preponderantemente hidrelétrico.

Diante do supracitado, para o cálculo do PLD são utilizados modelos computacionais que objetivam a solução ótima de equilíbrio entre utilizar a energia provida das hidrelétricas ou o armazenamento da água para utilização futura. Estes modelos se baseiam principalmente em parâmetros como condições hidrológicas, demanda de energia, preços de combustível, custo do deficit, entrada de novos projetos e disponibilidade de equipamentos de geração e transmissão para obter o despacho ótimo, estabelecendo a geração hidráulica e térmica para cada submercado no período em estudo (CCEE, 2021d).

Na cadeia de modelos, os estudos são coordenados entre si com diferentes horizontes de análise e distintos graus de detalhamento, representados pelos modelos computacionais NEWAVE, DECOMP E DESSEM, que têm como resultado o Custo Marginal da Operação (CMO) para cada submercado em base mensal, semanal e diária, respectivamente. O CMO é a base para a determinação do PLD. A principal diferença entre entre eles é que o PLD é limitado por preços máximo e mínimo estabelecidos anualmente pela ANEEL. Além disso, para calcular o PLD, são consideradas restrições de transmissão apenas entre 
submercados, ao passo que o CMO leva em conta restrições de transmissão tanto entre os submercados quanto internas aos mesmos. Vale ressaltar que o cálculo é baseado no despacho ex-ante, ou seja, antes da operação real do sistema.

A seguir, a Figura 1.1 representa o comportamento do PLD e do CMO para o submercados SE/CO, no período de janeiro/07 a dezembro/20, na qual é possível verificar de maneira qualitativa a elevada correlação entre o CMO e o PLD, bem como a aplicação dos limites máximos e mínimos do PLD, em cada ano, resultando nas suas saturações.

Figura 1.1 - Comparação CMO e PLD.

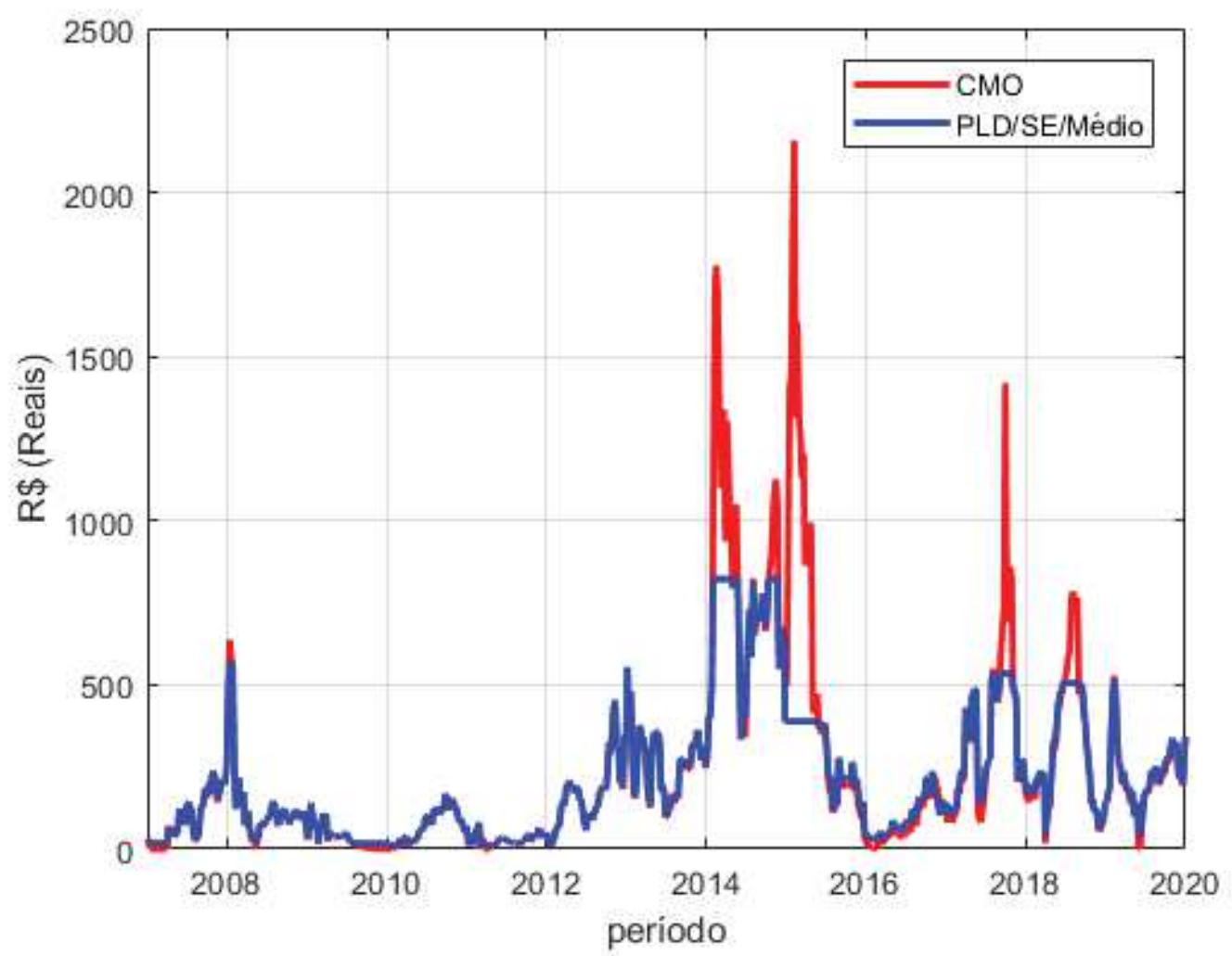

Fonte: (ONS, 2020) e (CCEE, 2021d).

De acordo com (CCEE, 2021e), os agentes atuantes nas áreas de geração, distribuição e comercialização de energia elétrica contabilizam 10.615 atualmente. Destes, 1.014 são consumidores livres, que podem negociar energia com qualquer fonte, 7461 consumidores especiais que podem contratar energia advinda de fontes limpas, como solar, eólica e pequenas centrais hidrelétricas (PCH), 391 comercializadores que são os intermediários entre o gerador e o consumidor final, 1.701 geradores e 48 distribuidores.

Ao longo dos anos, a migração para o Mercado Livre aumentou consideravelmente. Cada vez mais o consumidor se interessa por este mercado e quer operar neste modelo contratual, buscado vantagens econômicas. No entanto, a alta volatilidade do PLD, observada na Figura 1.1, é uma das maiores preocupações dos agentes do setor elétrico brasileiro, fundamentalmente no ACL. Os agentes que operam neste ambiente de contratação detêm 
diferentes estratégias no contexto da comercialização de energia, visando a maximização dos lucros. Quando ocorrem variações não esperadas no PLD, pode ocorrer um impacto financeiro significativo.

Diante do exposto, é evidenciada a importância de uma melhor compreensão de como o PLD se comporta, de forma a reduzir as suas incertezas nas análises dos agentes do setor, com a motivação de auxiliar na elaboração de estratégias de comercialização de energia, bem como reduzir os riscos envolvidos no processo de tomada de decisão. Uma vez que o PLD é contaminado por ruídos aleatórios, especialmente os de causas naturais hidrológicas, este torna-se um problema estocástico.

Assim, o problema probabilístico relatado centra-se na obtenção de um modelo de predição de resultados futuros. Para isso, faz-se necessário estudar técnicas que atendam a esta especificação. As Redes Neurais Artificiais (RNA) têm grande aplicabilidade, largamente relatada na literatura, no que concerne a predição de séries temporais, sendo desenvolvidas com base em modelos de sistemas de neurônios biológicos. Desta maneira, o presente trabalho propõe a aplicação de RNAs recorrentes, utilizando como entradas:

i PLD (Preço de Liquidação das Diferenças) (CCEE, 2021b);

ii Carga de Energia (CE) (ONS, 2021a);

iii Demanda Máxima (DM) (ONS, 2021c);

iv Energia Armazenada (EA) (ONS, 2021d);

v Energia Natural Afluente (ENA) (ONS, 2021e);

vi Geração de Energia (GE) (ONS, 2021f);

vii Intercambio de Energia (IE) (ONS, 2021g), e;

viii Custo Marginal de Operação (CMO) (ONS, 2021b).

Conforme citado anteriormente, o PLD possui grande relação com o CMO, diferindo nos momentos em que o os valores atingem os limites estabelecidos pela ANEEL. Nestes momentos específicos de saturação de preços, os modelos de identificação de sistemas, tais como as Redes Neurais Artificiais, ficam sem dados de referência para o aprendizado, uma vez que dados constantes não permitem aos modelos o conhecimento da próxima variação. Assim, optou-se pela predição do CMO, como forma de conhecer a tendência de variação do PLD.

Além disso, para aumentar a investigação de possibilidades na exploração da tendência futura do CMO, este trabalho também propôs a inserção de filtragem dos dados de saída da RNA recorrente. Este procedimento se deu de maneira a realimentá-la 
com suas saídas filtradas, para aumentar a acurácia na preservação das tendências dos dados, de modo que as variações decorrentes da alta volatilidade intrínseca dos dados não causassem o acúmulo exacerbado de erros na fase de treinamento da RNA. Assim, o objetivo principal da rede não é a predição exata do preço do CMO em uma determinada semana do futuro, e sim, acurada demonstração da tendência de preços, permitindo um planejamento antecipado por parte dos agentes do setor.

\subsection{Objetivos e motivações}

Diante do contexto descrito anteriormente, esta pesquisa tem como objetivo a investigação da tendência de variação de Preços no Mercado Livre de Energia, a partir da Predição do Custo Marginal de Operação por meio de Redes Neurais Artificiais Recorrentes com a inserção de filtragem dos dados de saída da RNA. A motivação é desenvolver uma metodologia de predição que auxilie as tomadas de decisões dos operadores do mercado livre de energia nos momentos de firmar contratos de compra e venda.

Nos trabalhos desenvolvidos por (NASCIMENTO, 2017), (NASCIMENTO; OLIVI; LIMA, 2018) e (NASCIMENTO et al., 2019), Redes Neurais Artificiais Recorrentes usando como fonte de conhecimento sobre os dados o próprio histórico (série temporal) de preços do PLD se mostraram eficientes na predição do PLD uma semana à frente por meio do treinamento Resilient Backpropagation. Para a predição de períodos maiores, a falta de informações na própria série temporal dificulta a obtenção de boas predições, já que o PLD não possui padrões cíclicos (que favorecem o aprendizado). Além disso, as saturações do PLD causadas pelos limites mínimo e máximo estabelecidos pela ANEEL fazem com que a RNA perca a referência, uma vez que dados constantes não permitem aos modelos o conhecimento da próxima variação, além da integração dos erros e da alta volatilidade dos dados. Esses aspectos são tratados na presente dissertação, através dos objetivos específicos definidos a seguir:

i Utilizar a previsão do CMO para conhecer a tendência de variação do PLD;

ii Inserção de mais variáveis como entrada da Rede Neural;

iii Análise estatística de correlação das variáveis de entrada da Rede Neural;

iv Análise de novos métodos de treinamento de Redes Neurais Artificiais;

v Propor um filtro na saída da Rede Neural Recorrente que auxilie na preservação das tendências dos dados, e;

vi Realizar simulações computacionais para verificação do funcionamento de todas as topologias estudadas e abordadas neste estudo. 


\subsection{Produção Científica}

O trabalho realizado durante o Mestrado discutido nesta dissertação resultou na publicação de um artigo sobre o mesmo assunto.

- NASCIMENTO, F. B. do.; OliVI, L. R.; LIMA, L. H. L., OLIVEIRA, L. W.; JÚNIOR, I. C. S. Weekly forecast of the Settlement Price of Differences in the Brazilian short-term market through recurrent artificial neural networks. Em: Anais do $\mathbf{1 4}^{\mathrm{O}}$ Simpósio Brasileiro de Automação Inteligente, 2019, Ouro Preto.

\subsection{Estrutura da dissertação}

A organização do presente trabalho se dá em cinco capítulos. O primeiro capítulo trata-se desta introdução, apresentando o tema proposto. O segundo capítulo trata de uma revisão bibliográfica da literatura e dos temas abordados no trabalho. O terceiro capítulo descreverá o desenvolvimento técnico utilizado na resolução do problema. O quarto capítulo mostra os resultados e suas implicações no tema proposto. O quinto capítulo conclui os resultados e aponta trabalhos futuros. 


\section{FUNDAMENTAÇÃO TEÓRICA}

Este capítulo faz uma revisão técnica acerca dos assuntos que serão tratados neste trabalho. Envolve uma descrição do setor elétrico brasileiro, o foco de aplicação do trabalho, e também uma descrição das técnicas propostas para aplicação ao problema de predição de preços no mercado livre de energia.

\subsection{O Setor Elétrico Brasileiro}

A atual estrutura do Setor Elétrico Brasileiro teve início com as reformas ocorridas no setor iniciadas na década de 90. Essas reformas foram motivadas basicamente pela ineficiência do modelo institucional existente, que colocava em risco a oferta e expansão do sistema energético.

Até 1995, o modelo do Setor Elétrico era composto basicamente por empresas verticalizadas, predominantemente estatais, onde o financiamento era feito através de recursos públicos. Toda atividade relacionada a energia elétrica era monopolizada, não havia competição, todos os consumidores eram cativos e o mercado era completamente regulado.

Em 07 de julho de 1995 ocorreu uma importante modificação institucional na estrutura do Setor Elétrico, quando foi promulgada a Lei nº 9.074 (BRASIL, 1995) que estabeleceu a criação do Produtor Independente de Energia e do Consumidor Livre de Energia, estabelecendo uma nova formatação da comercialização de energia elétrica no país. Esta Lei inseriu a possibilidade de uma empresa privada produzir e comercializar energia elétrica e estabeleceu os primeiros passos rumo à competição da comercialização de energia elétrica.

Essa necessidade de atrair investimentos privados se tornou tão evidente que em 1996, consultores nacionais e internacionais, liderados pela Coopers\&Lybrand foram contratados para a condução do programa de reforma do Setor Elétrico. Os resultados deste trabalho foram consolidados no Projeto Reestruturação do Setor Elétrico Brasileiro (RE-SEB), coordenado pelo Ministério de Minas e Energia (MME). Foi a primeira tentativa de estabelecer um modelo sustentável para a comercialização de energia no país e que formou as bases para o modelo institucional brasileiro existente hoje.

O RE-SEB previa a separação das empresas de energia em áreas específicas: geração, transmissão, distribuição e comercialização de energia, e incentivava a competição nos segmentos de geração e comercialização, mantendo sob regulação do Estado os setores de distribuição e transmissão de energia elétrica (SOUZA, 2008).

Essa necessidade de desverticalização das empresas de energia e incentivo de competição na geração e comercialização apresentou a necessidade de criação de uma 
estrutura regulatória. Para atender este anseio houve, em 1997, a constituição da Agência Nacional de Energia Elétrica (ANEEL) por meio do Decreto 2.335 (BRASIL, 1997a) e a criação do Conselho Nacional de Políticas Energéticas com a Lei 9.478 (BRASIL, 1997b).

Em consonância com a ANEEL criou-se, em 1998, o Operador Nacional do Sistema (ONS) que cria e aplica regras e normas para o gerenciamento harmônico da produção e transmissão de eletricidade e o Mercado Atacadista de Energia Elétrica (MAE), um ambiente para a realização das transações de compra e venda de energia elétrica.

O projeto RE-SEB findou-se em 1998 e as principais conclusões do mesmo foram: a necessidade de desverticalizar as empresas de energia elétrica, incentivar a competição na geração e comercialização e manter sob regulação os setores de transmissão e distribuição de energia elétrica. Contudo, a grave crise de abastecimento sofrida em 2001 pelo Setor Elétrico resultou na implementação de um plano de racionamento de energia elétrica bem como em propostas de alterações no modelo proposto, criadas pelo Comitê de Revitalização do Modelo do Setor Elétrico (NASCIMENTO, 2017).

Em 2003, obtiveram-se as premissas para o novo modelo institucional, que foram publicadas por meio das Medidas Provisórias 144 e 145. A Medida Provisória 144 (BRASIL, 2003a) dispunha sobre a comercialização da energia elétrica e, para sua comercialização criou-se uma instituição no sistema interligado dando continuidade às atividades do MAE, a Câmara de Comercialização de Energia Elétrica (CCEE) e a Medida Provisória 145 (BRASIL, 2003b) criava a Empresa de Pesquisa Energética (EPE), entidade responsável pelo planejamento do Setor Elétrico no longo Prazo.

Em 2004, as Medidas Provisórias 144 e 145 foram convertidas nas Leis 10.848 (BRASIL, 2004e) e 10.847 (BRASIL, 2004d), respectivamente. Estas leis são a base institucional e legal do novo modelo do Setor Elétrico Brasileiro. Ainda neste ano, o Comitê de Monitoramento do Setor Elétrico (CMSE) foi constituído pelo Decreto 5.175 (BRASIL, 2004c), houve também a regulamentação do Operador Nacional do Sistema (ONS) por meio do Decreto 5.081 (BRASIL, 2004a).

Em relação à comercialização, o Decreto 5.163 (BRASIL, 2004b), em julho de 2004, separou a comercialização em dois ambientes para a celebração de contratos de compra e venda de energia, com lógicas e estruturações distintas: O Ambiente de Contratação Livre (ACL) e o Ambiente de Contratação Regulada (ACR). No ACR as operações de compra e venda acontecem de forma a atender o mercado cativo e o ACL é o segmento do mercado onde acontecem as operações de compra e venda de energia livremente negociadas, firmadas por meio de contratos bilaterais.

As negociações nos dois ambientes acontecem conforme as regras e procedimentos de comercialização da CCEE, regulamentados através de resoluções da ANEEL. Além disso, também foi criado o Mercado de Curto Prazo, conhecido como mercado das diferenças 
onde ocorre o ajuste entre os volumes contratados e os volumes medidos de energia.

Um outro ponto importante do Decreto 5.163 é a separação de atribuições e deveres em diferentes instituições. O mapeamento organizacional apresentado na Figura 2.1 integra o modelo institucional vigente, implantado em 2004, o qual é fruto de um aprimoramento originado em 1998 com o projeto RE-SEB.

Figura 2.1 - Estrutura do Setor Elétrico Brasileiro.
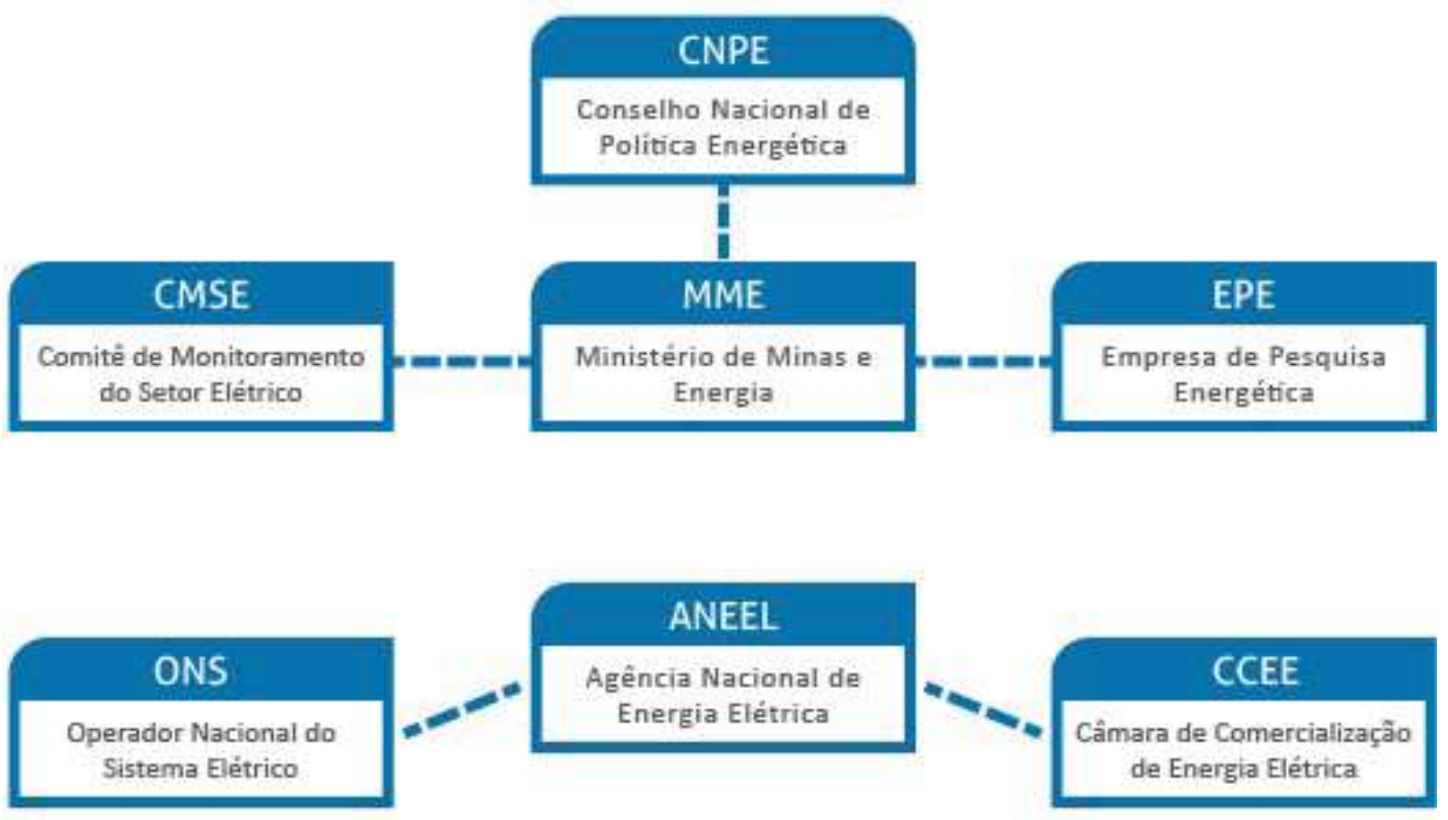

Fonte: (CCEE, 2021a).

O Conselho Nacional de Políticas Energéticas (CNPE) é responsável por traçar políticas energéticas nacionais e quem realiza a gestão destas políticas é o Ministério de Minas e Energia (MME). O acompanhamento e avaliação da segurança e continuidade no fornecimento de energia é responsabilidade do Comitê de Monitoramento do Setor Elétrico (CMSE).

A Agência Nacional de Energia Elétrica (ANEEL) regula a fiscalização no setor. A Empresa de Pesquisa Energética (EPE) faz o planejamento energético da expansão da oferta de energia no país, com estudos e pesquisas que ajudam a traçar as políticas e realizar a gestão. A operação física do sistema é feita pelo Operador Nacional do Sistema (ONS) e por fim, a Câmera de Comercialização de Energia Elétrica (CCEE) viabiliza as operações do mercado de energia elétrica, administrando as transações e realizando os leilões.

\subsection{A Formação do Preço de Liquidação das Diferenças}

No sistema elétrico brasileiro, a decisão sobre o despacho e a transmissão de energia elétrica é feita de forma centralizada pelo Operador Nacional do Sistema (ONS) que 
faz a programação da geração com base em otimização de custos. A metodologia para determinação do PLD é operacionalizada por modelos computacionais, que representam algoritmos de programação dinâmica dual estocástica. O NEWAVE é utilizado para programação de médio e longo prazo (até 5 anos) com discretização mensal. O modelo DECOMP com programação de prazo mais curto (2 meses) com discretização semanal e por fim, o modelo DESSEM que é o desdobramento de uma programação a curtíssimo prazo (até 1 semana) com discretização horária.

Esta cadeia de programas tem como função a gestão dos recursos energéticos do país de forma centralizada. Pretende-se minimizar o uso dos recursos energéticos atendendo a dois objetivos conflitantes: Assegurar o atendimento presente e futuro da carga, ou seja, evitar a possibilidade de racionamento e operar ao menor custo total. Sendo assim, a decisão sobre a quantidade de energia que cada usina ofertará, cabe ao ONS que libera o despacho de cada usina com base em uma ordem de mínimo custo até que seja possível atender completamente a demanda.

O sistema de geração de energia elétrica brasileiro é hidrotérmico com grande predominância de hidráulicas. A análise de seu comportamento é probabilística, pois a decisão sobre a utilização da água armazenada nos reservatórios (estoques de energia) está intimamente relacionada com a incerteza das afluências futuras.

A decisão de minimizar o consumo das termelétricas com despacho intensivo das hidrelétricas implica em menores custos, devido à economia de combustíveis, mas tende a aumentar o custo de operação futuro, em especial se as afluências hidrológicas forem baixas. Por outro lado, despachar de forma acentuada as termelétricas minimiza o consumo da água, preservando os níveis dos reservatórios hidrelétricos. Esta política ameniza o aumento do custo de operação futuro caso a previsão de chuvas seja desfavorável, mas implica no aumento do custo de operação em curto prazo devido à necessidade de despachar mais termelétricas. A Figura 2.2 mostra este processo de decisão e planejamento.

Conforme os autores de (SOUZA, 2013) a energia elétrica no Brasil possui características singulares, as quais pode-se citar:

- Não é possível armazená-la ou estocá-la no atacado para futuro uso;

- Incerteza da demanda;

- Dependente da hidrologia;

- Expansão da geração exige longo prazo.

Diante do exposto, o programa computacional conhece não somente a configuração do sistema, mas também as características passadas da hidrologia. Então ele projeta a variabilidade das hidrologias já verificadas no passado para o período a frente e verifica os 
Figura 2.2 - Cronograma de decisão para um sistema hidrotérmico.

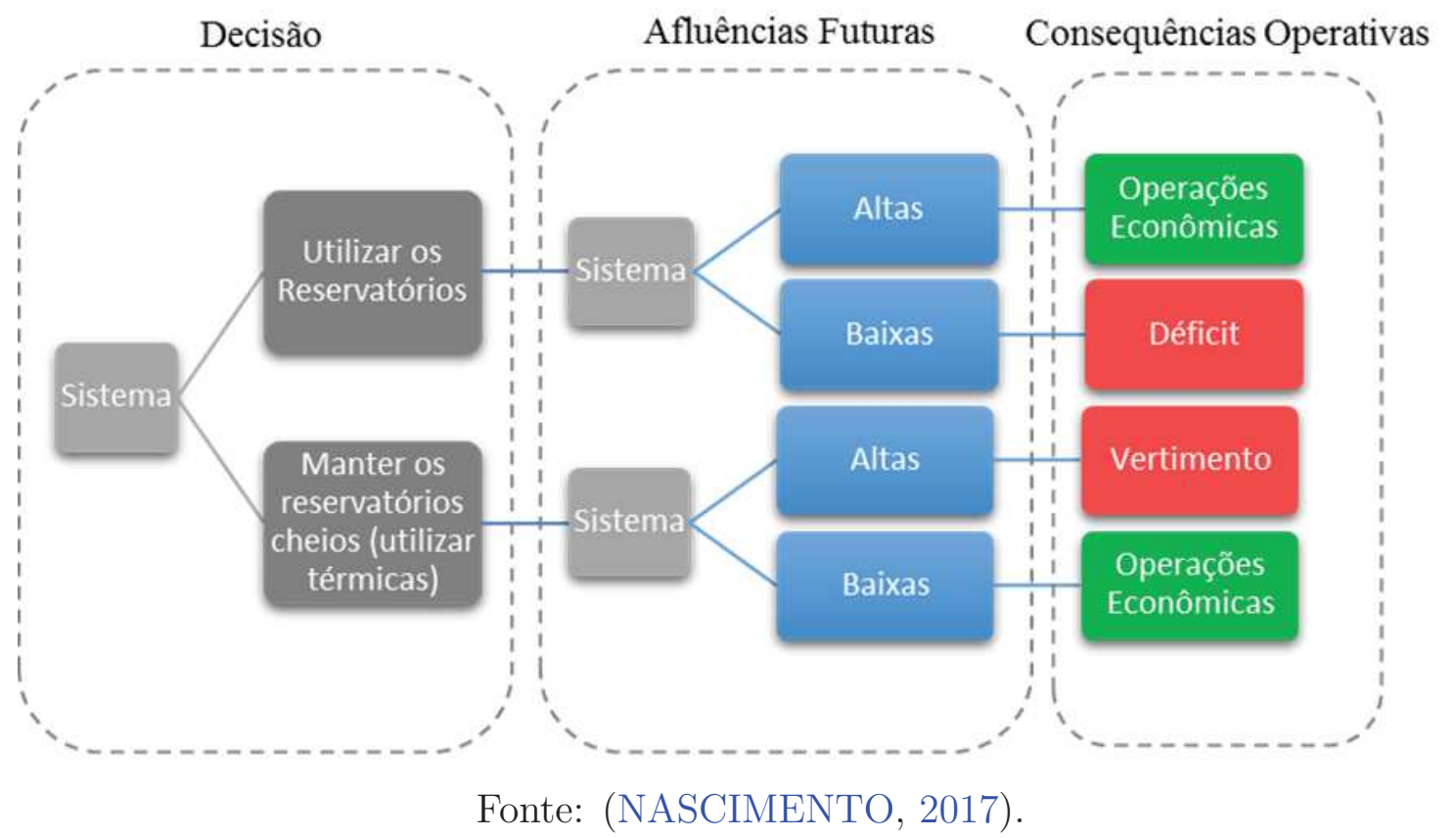

possíveis cenários hidrológicos futuros. A operação é simulada nesses cenários, objetivando uma tomada de decisão de operação que minimize o custo total. Além da otimização do parque gerador, é considerada a transmissão da energia.

O Brasil é territorialmente muito vasto com um extenso sistema de transmissão conectando as diversas regiões do país, que são divididas em 4 subsistemas: Norte, Nordeste, Sudeste/Centro-Oeste e Sul, conforme evidenciado na Figura 2.3. A interligação entre os subsistemas permite que os custos sejam reduzidos, por meio do intercambio de energia. Este intercambio também é analisado nas simulações.

Em síntese, os algoritmos de programação levam em consideração uma série de variáveis representativas das atuais condições hidrológicas do sistema, bem como as condições da trajetória de demanda de expansão física do sistema. De acordo com o CCEE (CCEE, 2021c), o NEWAVE tem o objetivo de determinar a estratégia de geração hidráulica e térmica minimizando o valor esperado do custo de operação para todo o período de planejamento. Um dos principais resultados desse modelo são as funções de custo futuro, que traduzem para o modelo de curto prazo o impacto da utilização da água armazenada nos reservatórios. O objetivo do DECOMP é determinar o despacho de geração das usinas hidrelétricas e termelétricas que minimiza o custo de operação ao longo do período de planejamento, dado o conjunto de informações disponíveis (previsões de cargas, vazões, disponibilidades, limites de transmissão entre submercados, função de custo futuro do NEWAVE, etc). Este modelo fornece a Função de Custo Futuro, resultado da estratégia de solução do curto prazo, para o acoplamento com o modelo de curtíssimo prazo - DESSEM. O objetivo do DESSEM é determinar o despacho de geração 
Figura 2.3 - Regiões do Sistema Interligado Nacional.

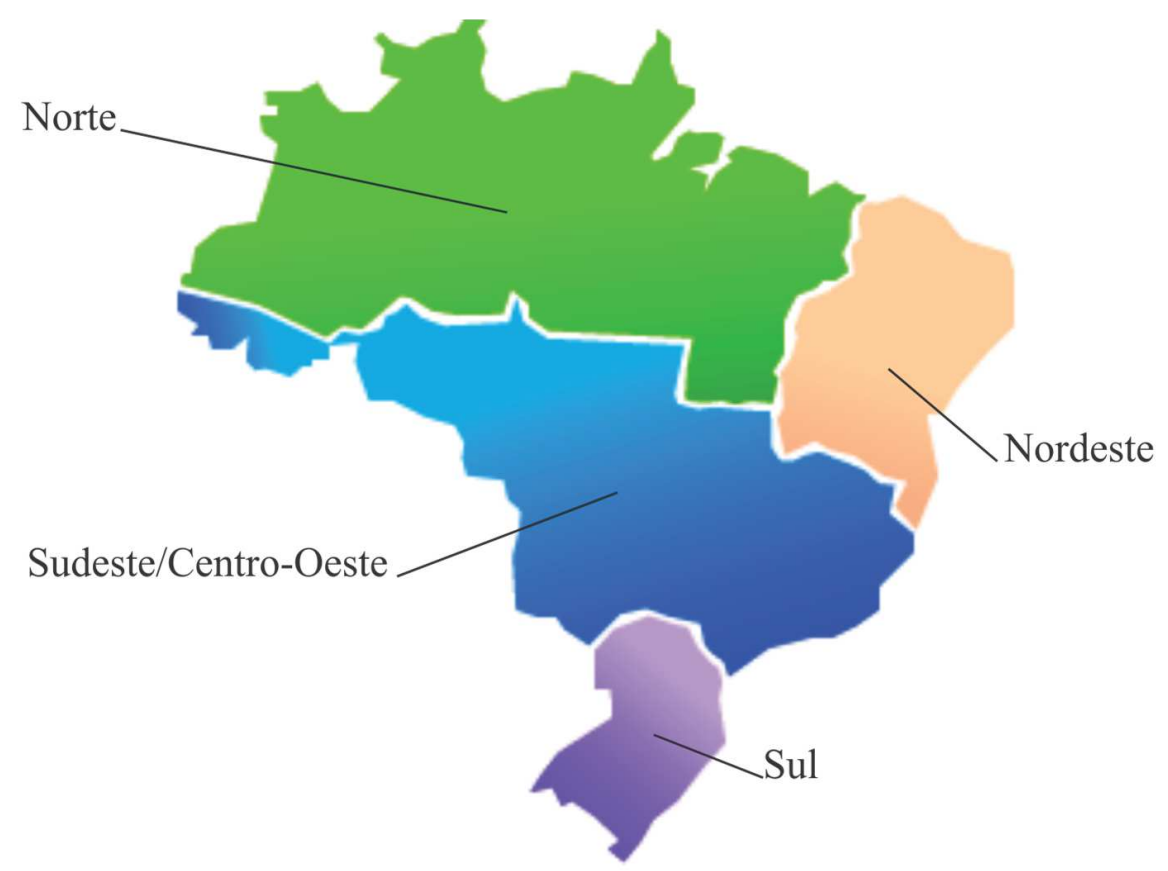

Fonte: (CCEE, 2021f), (NASCIMENTO, 2017).

das usinas hidrelétricas e termelétricas que minimiza o custo de operação ao longo do período de planejamento, bem como o custo marginal de operação para cada período e por submercado, dado o conjunto mais detalhado das informações (previsões de carga, vazões, geração eólica, disponibilidades, limites de transmissão entre subsistemas, função de custo futuro do DECOMP, etc).

Vale ressaltar que até 31 de dezembro de 2020, os valores oficiais do PLD eram calculados com base nos resultados da execução do modelo DECOMP. A partir de $1^{\mathrm{O}}$ de janeiro de 2021, os valores oficiais do PLD são calculados com base nos resultados da execução do modelo DESSEM.

\subsection{Predição do PLD}

O Preço de Liquidação das Diferenças é uma variável chave do setor elétrico brasileiro. O PLD propicia flexibilidade nas negociações, possibilita ajustes entre a energia contratada e a energia gerada, e é adotado como referência para contratos de longo prazo. (LEITE, 2013)

As incertezas associadas ao planejamento de um sistema com predominância da geração hidrelétrica conferem ao PLD acentuada volatilidade. Esta volatilidade é uma das maiores preocupações dos agentes do setor elétrico, fundamentalmente no ACL. Por conseguinte, a predição dessa variável tem se mostrado um dos grandes desafios enfrentados por pesquisadores nos últimos anos. 
Reston Filho (FILHO, 2014) desenvolveu em seu trabalho um modelo híbrido de predição do preço da energia no mercado de curto prazo. Sua abordagem combina modelos de Redes Neurais Artificiais (RNA) e filtros autorregressivos integrados de médias móveis (ARIMA), aplicando um processo em dois passos: Primeiramente, o autor realiza a predição de variáveis explanatórias e então, os valores futuros destas variáveis são utilizados para a predição dos preços de energia. O modelo desenvolvido é capaz de estimar o PLD até 12 passos (semanas) a frente, aproximadamente 3 meses. Os resultados são bons para os doze passos à frente, mostrando resultados de validação coerentes com os preços futuros reais.

Rodrigues (RODRIGUES, 2009) propôs uma RNA com dados de entrada disponibilizados pelo ONS e pela CCEE, a saber: preços do mercado spot, armazenamento de água, energia natural afluente, energia máxima, geração em Itaipu, hidrelétricas (exceto Itaipu), térmica convencional, térmica nuclear, fonte eólica, carga do sistema, intercâmbios (transmissão de energia entre os submercados) e internacional (importação ou exportação de energia para Argentina, Paraguai ou Venezuela). Foram utilizados dados de 6 semanas anteriores ao dia t, tendo como saída da rede o preço previsto para o dia t. Os resultados foram apresentados para os quatro submercados brasileiros.

No geral, as RNAs apresentaram resultados razoáveis frente à heterogeneidade dos dados de entrada. Testes de sensibilidade foram realizados a fim de avaliar o comportamento da rede sem as variáveis carga e energia armazenada e constatou-se resultados com elevada imprecisão, demonstrando a dependência forte de tais entradas. O trabalho de (COELHO, 2018) também faz uso das Redes Neurais Artificiais de forma a realizar predições do Preço de Liquidação das Diferenças. A autora fez uso de uma Rede Neural Recorrente em 5 cenários distintos, realizando alterações nos dados de entrada: dados originais, dados com remoção de outiliers, correção monetária dos dados com base no IGP-M, utilização de dados a partir do ano de 2015 (após nova regulamentação de limites máximo e mínimo) e uma combinação das anteriores. As previsões apresentaram resultados bastante distintos para cada cenário gerado. As predições foram feitas para 20 meses e 5 anos a frente, não apresentando resultados com alta confiabilidade.

Redes Neurais Artificiais são modelos computacionais propícios para o aprendizado de padrões e consequente predição de dados e comportamentos. São os modelos mais empregados na literatura e, por este motivo, também serão motivo de investigação neste trabalho. Em decorrência disto, faz-se a seguir uma revisão literária à respeito das Redes Neurais, com suas principais características e aplicações.

\subsection{Redes Neurais Artificiais}

O cérebro é o órgão mais complexo do corpo humano onde as bilhões de células nervosas possuem interconexões. Algumas destas células, os neurônios, possuem ramificações 
ou conexões que se estendem desde o cérebro até as partes mais distantes do corpo. O cérebro é especialmente bom para desempenhar funções como reconhecimento de padrões, controle motor, percepção, tomada de decisões, comunicação e predição.

O primeiro registro do modelamento matemático inspirado em um neurônio biológico data de 1943, onde o neurofisiologista Warren McCulloch e o matemático Walter Pitts desenvolveram um trabalho intitulado "A logical calculus of the ideas immanent in nervous activity" (MCCULLOCH; PITTS, 1943) que fazia uma analogia entre células vivas e o processo eletrônico, simulando o comportamento do neurônio natural. O modelo consistia basicamente em um neurônio que executava uma função lógica, onde os nós produziam somente resultados binários e as conexões transmitiam exclusivamente zeros e uns.

Em 1949, o psicólogo Donald Hebb, demonstrou que a capacidade da aprendizagem em Redes Neurais biológicas vem da alteração da eficiência sináptica, isto é, a conexão somente é reforçada se tanto as células pré-sinápticas quanto as pós-sinápticas estiverem excitadas. Hebb foi o primeiro a propor uma lei de aprendizagem específica para as sinapses dos neurônios, conhecida como a Lei de Hebb (HEBB, 1949).

O trabalho de desenvolvimento de modelos matemáticos inspirados no neurônio biológico foi continuado por diversos pesquisadores, dando existência a diversos algoritmos de aprendizado e estruturas neuronais. Dentre as linhas de pesquisa que surgiram, destacase o modelo Perceptron, apresentado por Frank Rosenblatt em seu livro "Principles of neurodynamics" (ROSENBLATT, 1961). Nele, os neurônios eram organizados em camadas de entrada e saída, onde os pesos das conexões eram adaptados a fim de se atingir a eficiência sináptica usada no reconhecimento de caracteres.

O Perceptron atraiu interesses devido à sua capacidade de reconhecer padrões simples e em 1960 surgiu a rede Adaline (ADAptive LINear Element) e a Madaline (Many Adaline), propostas por Widrow \& Hoff (WIDROW, 1962). São redes com aprendizado fundamentado na regra Delta, conhecida como algoritmo de aprendizado LMS (Least Mean Square). Em 1969, foi constatado por Minsky \& Papert (MINSKY; PAPERT, 1969) que um neurônio do tipo Perceptron só é capaz de resolver problemas com dados de classes linearmente separáveis. Esta limitação do uso das Redes Neurais deu início ao primeiro grande inverno das Redes Neurais, uma era de poucas novidades, com cortes nos investimentos e baixa atenção ao setor.

Em 1982 houve uma retomada das pesquisas com a publicação dos trabalhos do físico biólogo John Hopfield relatando a utilização de redes recorrentes baseadas em funções de energia (HOPFIELD, 1982). No final dos anos 1980, com o impulso inicial do trabalho de Hopfield e outros pesquisadores, um interesse significativo ressurgiu na área. A retomada definitiva se deve à criação de algoritmos mais robustos e eficientes, ao desenvolvimento de computadores com maior capacidade de processamento e a novas descobertas sobre o sistema nervoso biológico (SILVA, 2010). 
Um dos destaques do período, foi a publicação do livro de David E. Rumelhart, Geoffrey E. Hinton e Ronald J. Williams, em 1986 (RUMELHART; WILLIANS, 1986). Eles introduziram o poderoso método de treinamento chamado Backpropagation, que permitia o ajuste de pesos em uma rede multicamadas. A partir desta proposição, foi despertado o interesse em estudos sobre RNAs novamente e de forma definitiva. Deste ponto, até os dias atuais as Redes Neurais Artificiais vêm sendo aplicadas em diversas áreas do conhecimento humano.

Para o número de camadas de uma rede neural, tem-se o Teorema da Aproximação Universal das Redes Neurais Artificias, derivado do Teorema de Andrey Kolmogorov (1957) e complementado por George Cybenko (1989). Este teorema estabelece que apenas uma única camada escondida com um número finito de neurônios é capaz de aprender e aproximar qualquer função (SILVA, 2010). Portanto, com apenas uma camada é possível reproduzir qualquer sequência de dados por meio de uma rede neural artificial, sendo um importante ponto de partida para o problema em questão apresentado neste trabalho.

No entanto, o problema proposto pode se revelar mais complexo que o esperado. Assim, mais camadas são passíveis de serem utilizadas caso o problema requeira mais que uma mera aproximação de funções. É possível que a captura das nuâncias do problema necessite de conexões espaciais de ordens maiores, requerendo, portanto, mais camadas escondidas, da mesma maneira que se faz no reconhecimento de imagens por meio de redes profundas (deep learning).

\subsubsection{Redes Recorrentes}

A capacidade de generalização de uma RNA está intimamente relacionada com a escolha da arquitetura de rede e com o algoritmo de aprendizado utilizado na fase de treinamento da rede. As arquiteturas podem ser divididas em duas principais categorias: redes alimentadas adiante e redes recorrentes (ou redes realimentadas). As redes recorrentes, em especial, são adequadas para o processamento dinâmico de informações, ou seja, em sistemas cujos comportamentos são considerados variantes no tempo ou dependentes dele. Como exemplo de aplicação tem-se a predição de séries temporais, em que há correlação entre dados subsequentes no tempo (DUDA; HART; STORK, 2000).

Conforme evidenciado na Figura 2.4, essas redes possuem neurônios adicionais atrasados que transmitem informações de camadas posteriores para anteriores ou entre neurônios da mesma camada, criando uma autorregressão que atua como memória interna. Esta autorregressão é conhecida como Time Delay Neural Network (TDNN) (SILVA, 2010).

A arquitetura de rede com saídas recorrentes às entradas permite a partir da realimentação de sinais produzidos em instantes anteriores, a recuperação de respostas passadas. Por conseguinte, é possível dizer que esta tipologia possui memória, ou seja, é capaz de relembrar saídas passadas de forma a produzir a resposta atual ou futura. Sendo 
Figura 2.4 - Topologia de rede recorrente.

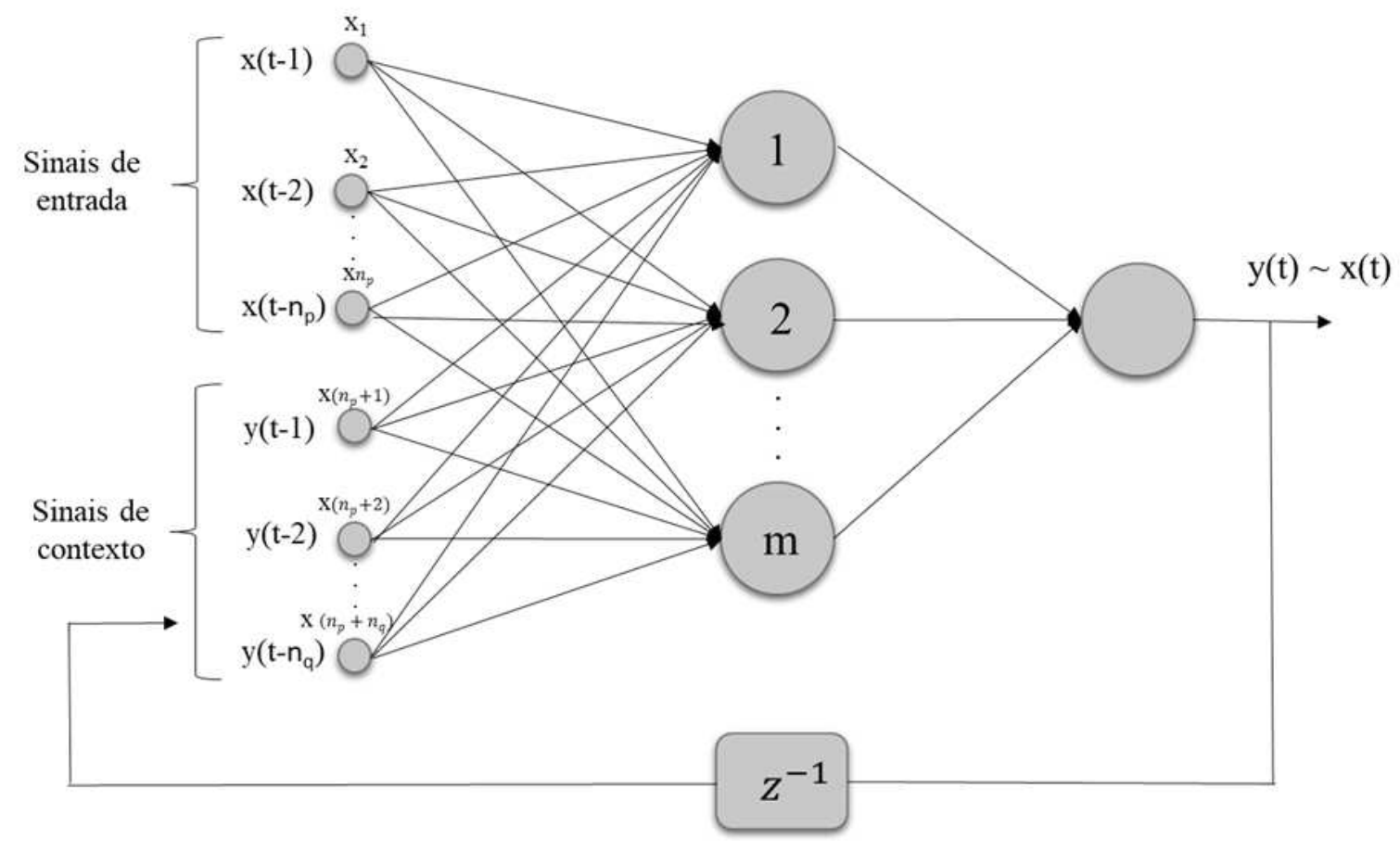

Atraso temporal

Fonte: (NASCIMENTO, 2017).

assim, a predição dos valores futuros, a partir do instante $t$, também terá influência dos valores anteriores produzidos pela saída da rede:

$$
x(t)=f\left(x(t-1), x(t-2), \ldots, x\left(t-n_{p}\right), y(t-1), y(t-2), \ldots, y\left(t-n_{q}\right)\right)
$$

em que $\mathrm{n}_{\mathrm{p}}$ é a ordem do preditor e indica o número de amostras anteriores necessárias para a estimação de $\mathrm{x}(\mathrm{t})$ e o valor $\mathrm{n}_{\mathrm{q}}$ expressa a quantidade de saídas passadas que serão utilizadas na estimação de $\mathrm{x}(\mathrm{t})$.

Conforme evidenciado por (SILVA, 2010), a configuração de realimentação confere à rede a capacidade de realizar, de maneira implícita, o mapeamento entre entradas e saídas de processos tanto não-lineares como variantes no tempo, tornando-se uma ferramenta bem flexível para aplicações envolvendo identificação de sistemas.

\subsubsection{Métodos de Treinamento}

As Redes Neurais Artificiais se destacam pela capacidade de aprendizado a partir da apresentação de amostras que representam o comportamento do sistema. Após o aprendizado da relação das entradas e saídas, a rede se torna capaz de produzir uma saída próxima da desejada a partir de quaisquer dados fornecidos às entradas. Portanto, o algoritmo de aprendizado da rede consiste na aplicação de um conjunto de passos com o objetivo de fazer o ajuste dos pesos sinápticos dos neurônios, tendo em vista sintonizar a rede para que as respostas produzidas por ela estejam próximas dos valores desejados. 
Há, na literatura, diversos algoritmos usados para o treinamento das redes. Basicamente, eles diferem entre si pelo modo como os pesos sinápticos de um neurônio são modificados. Cada algoritmo apresenta vantagens e desvantagens quanto ao ajuste do peso, a escolha está relacionada com a categoria de problema a ser solucionado.

A lei de aprendizado de Hebb, desenvolvida em 1949, permite o ajuste de pesos e limiar do Perceptron visando a classificação de padrões entre duas classes. Resumidamente, se a saída da rede coincide com o esperado, os pesos e limiares são incrementados de forma proporcional ao sinal de entrada, caso a saída da rede seja diferente do valor esperado os pesos sinápticos e limiar são decrementados. O processo descrito se repete para todas as amostras do treinamento até que a saída da rede seja próxima à saída desejada de cada amostra.

Outro método de treinamento popularmente conhecido, foi desenvolvido por Widrow \& Hoff, conhecido por regra Delta, algoritmo LMS (Least Mean Square) ou método do Gradiente Descendente. A ideia desenvolvida com este algoritmo consiste em minimizar a diferença entre a saída desejada e a resposta do combinador linear (composição das entradas ponderadas pelos respectivos pesos adicionada do limiar de ativação). Objetiva-se um vetor de pesos ótimo, tal que o erro quadrático sobre o conjunto de amostras seja o menor possível.

Para problemas que não são linearmente separáveis, é necessária a utilização de uma rede de múltiplas camadas. O algoritmo Backpropagation ou algoritmo de retropropagação do erro é bastante conhecido e aplicado no decorrer do processo de treinamento deste tipo de RNA. A primeira fase deste algoritmo é conhecida como forward, onde as entradas de uma amostra do conjunto de treinamento são inseridas na rede e seu efeito se propaga através dela desde a entrada, passando camada por camada, até a produção da saída. Logo em seguida, esta saída é comparada aos resultados desejados, e os respectivos sinais de erros são calculados. Sequencialmente na fase backward, os pesos das conexões são atualizados, baseados nos sinais de erro. A transmissão dos sinais de erro é feita da camada de saída em direção à camada de entrada. São realizadas sucessivas aplicações das duas fases de forma que os pesos se ajustem com o passar das iterações até que um critério de parada pré estabelecido seja atingido.

Desde seu lançamento, diversas variações do Backpropagation foram intensamente desenvolvidas. Tais variações buscam tornar o processo de convergência mais rápido e eficiente. Dentre elas, podem-se citar a inserção do momentum, o resilient-backpropagation, o ADAM (Adaptive Moment Estimation) e o método quasi-Newton Levenberg-Marquardt.

Uma das variações mais simples do Backpropagation é a inserção do termo de Momentum, em consonância com o conceito físico. Este parâmetro, que varia entre zero e um, pondera o quanto houve de variação entre duas iterações anteriores e sucessivas das matrizes de peso. A aceleração no processo de convergência acontece pois é levada em 
consideração o quão afastada da solução final está a solução atual. Basicamente, quando a solução atual estiver longe da solução final, a variação na direção oposta ao gradiente da função erro quadrático entre duas iterações sucessivas também será grande. Neste cenário adiciona-se um incremento mais significativo na matriz de pesos. Entretanto, quando as variações nas matrizes de peso forem pequenas, a variação do erro quadrático entre duas iterações sucessivas também será, o que significa que a solução está próxima da solução atual. Neste cenário, tem-se uma pequena contribuição do termo Momentum.

No Resilient-Backpropagation (RIEDMILLER; BRAUN, 1993) apenas o sinal da derivada do gradiente da função de erro é levado em consideração para indicar a direção da atualização dos pesos. Desta forma, é possível eliminar a influência prejudicial do tamanho da derivada parcial na etapa de peso. Assim sendo, ao considerar duas iterações sucessivas, se os sinais do gradiente forem os mesmos, a taxa de aprendizado pode ser incrementada em razão de estar distante de um ponto de mínimo da função de erro. Em contrapartida, deve-se diminuir a taxa de aprendizagem, quando os sinais do gradiente forem diferentes, pois isso implica que o ponto de mínimo da função foi ultrapassado.

O ADAM é um algoritmo de treinamento de Redes Neurais Artificiais baseado na utilização dos dois primeiros momentos estatísticos, respectivamente a esperança e a variância, de maneira que os dados preditos convirjam para uma média otimizada em termos de espalhamento estatístico, sendo um dos métodos mais indicados para dados estocásticos (P.KINGMA; BA, 2014).

O algoritmo de Levenberg-Marquardt (HAGAN; MENHAJ, 1994) é um método gradiente de segunda ordem do tipo quasi-Newton. Diferentemente do Backpropagation, que é um método de primeira ordem, de descida do gradiente, o algoritmo de LevenbergMarquardt é uma aproximação do método de Newton. Nele, utiliza-se a $2^{\mathrm{o}}$ derivada (Hessiana) aproximada, esta aproximação é feita a partir do Jacobiano.

De acordo com (DAMETTO, 2018), o método de otimização $A D A M$ proposto por (P.KINGMA; BA, 2014) é utilizado na otimização de funções estocásticas, sendo apropriado para problemas com muito ruído. Trata-se de um método adaptativo de primeira ordem, baseado na derivada da função objetivo, ou seja, o gradiente. Ele trabalha com o conceito de Momentos estatísticos para construir a adaptação e atualização dos pesos sinápticos da Rede Neural.

O método $A D A M$ é baseado no primeiro e segundo momentos, em que o primeiro momento é dado diretamente pelo gradiente, e o segundo momento pelo quadrado do gradiente. O primeiro momento faz a convergência imediata do peso sináptico, enquanto o segundo momento, que é a medida de espalhamento (variância), acelera e atenua a oscilação da descida do gradiente.

O treinamento do ADAM é baseado no Backpropagation, configurando uma extensão 
do mesmo com a utilização do conceito de momentos. Ele opera basicamente em uma sequência de dois passos. O primeiro passo consiste na propagação do sinal da entrada à saída. As saídas calculadas, tendo como base os pesos sinápticos da rede, são comparadas com os resultados desejados por meio de uma equação de erro quadrático. Caso a amplitude do erro seja alta, significa que as saídas da rede são muito diferentes dos resultados desejados, e então se faz necessário o ajuste dos pesos sinápticos. Então, o sinal de erro é retropropagado modificando os pesos das conexões das camadas internas.

O ajuste dos pesos é feito enquanto o erro de comparação, no caso o erro quadrático médio, for menor que um limiar pré-estabelecido e segue o seguinte encadeamento: na inicialização do algoritmo, as taxas de aprendizado do primeiro e segundo momento $\beta_{1} \mathrm{e}$ $\beta_{2}$ são configuradas. As variáveis do primeiro e segundo momentos, respectivamente $m_{0} \mathrm{e}$ $v_{0}$, são inicializados como nulos na primeira rodada. Semelhantemente ao Backpropagation, o $A D A M$ faz uma manipulação do gradiente, que é um vetor que aponta na direção de máximo crescimento da função. Logo, é possível obter a região de mínimo crescimento através da direção oposta do gradiente e assim garantir que os pesos obtidos ajustem o erro em seu menor valor.

Com base no cálculo do gradiente $g_{t}$ e a passagem das iterações $t$, é possível obter o primeiro e segundo momentos, conforme as Equações 2.2 e 2.3:

$$
\begin{aligned}
m_{t} & \leftarrow \beta_{1} m_{t-1}+\left(1-\beta_{1}\right) g_{t} \\
v_{t} & \leftarrow \beta_{2} v_{t-1}+\left(1-\beta_{2}\right) g_{t}^{2}
\end{aligned}
$$

Em seguida, ajustam-se os momentos, de forma a evitar divisões por zero (por meio de um valor bastante pequeno $\epsilon$ ) bem como reescalar o tamanho do ajuste, conforme as Equações 2.4 e 2.5:

$$
\begin{aligned}
& \hat{m}_{t} \leftarrow \frac{m_{t}}{\left(1-\beta_{1}^{t}\right)} \\
& \hat{v}_{t} \leftarrow \frac{v_{t}}{\left(1-\beta_{2}^{t}\right)}
\end{aligned}
$$

Por fim, os parâmetros da rede são calculados e atualizados conforme 2.6:

$$
\Theta_{t} \leftarrow \Theta_{t-1}-\alpha \frac{\hat{m}_{t}}{\left(\sqrt{\hat{v}_{t}}+\epsilon\right)}
$$

Após o ajuste, as saídas da rede são calculadas com base nos novos valores de peso. A saída gerada é comparada com a saída desejada e o erro obtido é comparado com um limiar pré-estabelecido. Se porventura, o erro calculado for menor que o limiar, tem-se que a resposta da rede é satisfatória e generaliza bem os dados que se deseja aprender e o algoritmo é encerrado. No entanto, caso a resposta seja negativa é preciso fazer o ajuste 
dos pesos sinápticos novamente e o processo se repete até que a condição de erro mínimo (limiar) seja alcançada.

\subsection{Filtragem}

O termo filtro é usado frequentemente para descrever um objeto físico ou programa de computador utilizado em um conjunto de dados ruidosos com o objetivo de extrair determinadas informações responsáveis pela degradação dos dados (HAYKIN, 1996).

Os filtros podem ser classificados em duas categorias principais que se diferem tanto no funcionamento quanto na montagem física: os filtros analógicos e os digitais. Os filtros analógicos utilizam circuitos eletrônicos analógicos compostos por uma combinação de resistores, capacitores e indutores para produzir o efeito de filtragem desejado. Já os filtros digitais utilizam processamento digital para a realização de cálculos numéricos nas amostras do sinal de entrada. Eles são representados por equações discretas que ao serem aplicadas em um sinal digital de entrada $\mathrm{x}(\mathrm{n})$, produzem uma saída $\mathrm{y}(\mathrm{n})$ com frequências dentro de uma faixa selecionada.

Os filtros digitais são programáveis, ou seja, tem sua operação determinada por um programa armazenado na memória do processador. Diferentemente dos filtros analógicos que para serem alterados é preciso realizar alterações no hardware (circuito eletrônico), os filtros digitais podem facilmente ser alterados. Além disso, os circuitos de filtros analógicos são compostos por componentes ativos, sujeitos a variações de alguns parâmetros como: temperatura e valores devido à construção dos componentes, o que os tornam menos estáveis que os filtros digitais, que não estão sujeitos à essas variações.

\subsubsection{Filtros Digitais}

Classificam-se os filtros digitais a partir do comprimento da sua sequência de resposta ao impulso como Filtro de Resposta ao Impulso Finita (FIR - Finite Impulse Response) e Filtro de Resposta ao Impulso Infinita (IIR - Infinite Impulse Response). Em FIR a resposta produzida é sem distorção na fase do sinal e é sempre estável pois não são recursivos, e nos filtros IIR a resposta produzida é defasada em relação ao sinal filtrado.

Nos filtros do tipo FIR, a resposta ao impulso possui duração finita e o cálculo dos valores de saída presentes não sofrem influência dos valores de saída passados, ou seja, é um filtro de natureza não recursiva. A saída de um filtro FIR digital genérico é dado por:

$$
y(n)=h_{0} x(n)+h_{1} x(n-1)+\ldots+h_{P} x(n-P)
$$

em que $\mathrm{P}$ é a ordem do filtro, $\mathrm{x}(\mathrm{n})$ é o sinal de entrada, $\mathrm{y}(\mathrm{n})$ o sinal de saída e $h_{i}$ os coeficientes do filtro. A equação apresentada anteriormente também pode ser escrita na 
forma apresentada a seguir:

$$
y(n)=\sum_{i=0}^{P-1} h_{i} x(n-i)
$$

Já nos filtros digitais do tipo IIR, a resposta ao impulso possui uma duração infinita e a saída adquirida em um determinado instante depende da entrada atual e das saídas oriundas de instantes anteriores, sendo classificado como um filtro de natureza recursiva. A representação da saída é dada por:

$$
y(n)=a_{0} x(n)+a_{1} x(n-1)+a_{2} x(n-2)+\ldots-\left[b_{1} y(n-1)+b_{2} y(n-2)+\ldots\right]
$$

em que $\mathrm{x}(\mathrm{n})$ é o sinal de entrada, $\mathrm{y}(\mathrm{n})$ o sinal de saída e $a_{i}$ e $b_{i}$ são os coeficientes de recursão do filtro. A expressão anterior também pode ser representada conforme a seguir:

$$
y(n)=\sum_{i=0}^{N} a_{i} x(n-i)-\sum_{k=1}^{M} b_{k} y(n-k)
$$

A escolha do tipo de filtro a ser utilizado deve ir de encontro ao que produz um melhor resultado para a solução desejada. Dentre os filtros digitais destacam-se os filtros de frequência seletivas (filtros de Butterworth, Chebyshev, Elíptico, dentre outros) e os filtros ótimos (Wiener e Kalman).

Os filtros seletivos em frequência, podem ser: passa-baixa, passa-alta, passa-faixa e rejeita-faixa. Um filtro passa-baixa tem a característica de transmitir as baixas frequências de um sinal (banda de passagem) e atenuar suas altas frequências (banda de rejeição). Em contrapartida, os filtros passa-alta permitem a passagem de sinais de alta frequência e reduz a intensidade de sinais de baixa frequência. De forma semelhante, tem-se o funcionamento dos filtros passa-faixa e rejeita-faixa, onde é permitido que uma faixa entre frequências de referências passe livremente ou sejam atenuadas, respectivamente.

\subsubsection{Filtro de Média Móvel}

O filtro média móvel (MAF - Moving Average Filter) é um filtro passa-baixa que possui resposta impulsional finita (FIR). Este tipo de filtro é elementar em processamento digital de sinais, principalmente por ser o filtro digital mais fácil para entender e utilizar. Apesar de sua simplicidade, o filtro média móvel é interessante para reduzir o ruído aleatório pois mantém uma resposta de degrau nítida. Isso o torna o filtro principal para sinais codificados no domínio do tempo (SMITH, 1999).

Como o próprio nome sugere, o filtro média móvel opera realizando o cálculo da média de um número de pontos do sinal de entrada de forma a produzir os pontos no sinal de saída. Esta média vai se alterando, entre os valores do sinal em questão. Na forma de equação, tem-se:

$$
y[i]=\frac{1}{M} \sum_{j=0}^{M-1} x[i+j]
$$


em que x é o sinal de entrada, y é o sinal de saída e M é o número de pontos usados na média móvel. Por exemplo, em um filtro média móvel com janela de cinco intervalos, o sinal de saída do décimo dado é escrito por:

$$
y[10]=\frac{x[10]+x[9]+x[8]+x[7]+x[6]}{5}
$$

Como alternativa, o grupo de pontos do sinal de entrada pode ser escolhido simetricamente em torno do ponto de saída:

$$
y[10]=\frac{x[8]+x[9]+x[10]+x[11]+x[12]}{5}
$$

As equações 2.12 e 2.13 exemplificam o filtro média móvel simples, um dos mais comuns. Além deste, os filtros de média móvel cumulativa e média móvel ponderada são comumente utilizados.

A teoria dos filtros ótimos é desenvolvida com base em um sinal de erro. Este sinal de erro é definido como a diferença ente o sinal desejado e o sinal estimado, a saída do filtro. Vários modelos foram desenvolvidos visando uma otimização do sinal de erro, dentre esses métodos pode-se destacar o método dos mínimos quadrados. Os filtros de Wiener e Kalman são baseados na teoria dos mínimos quadrados, que consiste em minimizar a soma dos erros quadráticos médios em termos estocásticos.

\subsubsection{Filtro de Kalman}

O filtro de Kalman, foi proposto em 1960 por Rudolf E. Kalman (KALMAN, 1960). O filtro de Wiener era largamente utilizado em várias pesquisas. Contudo, este filtro apresenta limitações em relação aos dados de entrada, que precisam ser estacionários. Sendo assim, o filtro de Wiener não era capaz de solucionar problemas dinâmicos.

No filtro de Kalman, o comportamento de um sistema dinâmico é descrito por um conjunto de variáveis de estados. As variáveis de estados contêm todas as informações necessárias sobre o comportamento do sistema de forma que dados os valores presentes e passados da entrada, pode-se determinar os estados futuros do sistema (KAILATH, 1980).

O advento das comunicações digitais, principalmente o surgimento e evolução dos computadores digitais, provocou uma grande utilização do algoritmo de Kalman, notadamente na área cientifica. Dentre os fatores que favoreceram a popularidade do filtro de Kalman, pode-se destacar:

- Utilização de estruturas recursivas;

- Manipulação da álgebra matricial simples, que possibilita sua implementação em computador digital; 
- Ampla aplicabilidade em várias áreas da engenharia (onde a estimação de estados é encontrada com frequência);

- Adaptabilidade a aplicações não-lineares.

Como mencionado anteriormente, o filtro de Kalman visa estimar os estados de um sistema dinâmico. Ou seja, a partir das medidas do sistema, seu modelo e as estatísticas dos ruídos que atuam tanto nas medidas quanto no modelo do sistema, determina-se uma estimativa dos valores dos estados do sistema no decorrer do tempo.

O Filtro de Kalman é frequentemente implementado no formato de propagaçãoatualização (projeção-correção). As equações de propagação são responsáveis por projetar a estimativa do estado corrente e da matriz de covariância, já as equações de atualização são responsáveis pela realimentação, ou seja, incorporam uma nova medida para obter uma estimativa atualizada (melhorada). Resumidamente, a etapa de projeção é realizada inicialmente baseando-se na estimativa atual do estado. Em seguida, após receber uma nova medição, a etapa de correção é realizada.

Para a implementação do filtro, a princípio é feita a projeção (a priori) da estimativa do estado $\widehat{x}$, conforme Equaçao 2.14, e da covariância do erro (matriz P), conforme Equação 2.15. Nesta etapa o vetor estimado de estado $\widehat{x}_{\mathrm{k}}$ é atualizado em função do estado anterior do tempo $k-1$. Também é feita a projeção (a priori) do erro de covariância, que é uma pré atualização da matriz $\mathrm{P}$ envolvendo a soma da matriz de estados do sistema com a matriz Q que é a matriz de covariância do ruído do sistema. A matriz Q é traçada pelo projetista de acordo com o conhecimento do processo.

$$
\begin{gathered}
\hat{x}_{k \mid k-1}=A \hat{x}_{k-1 \mid k-1}+B u_{k-1} \\
P_{k \mid k-1}=A P_{k-1 \mid k-1} A^{T}+Q
\end{gathered}
$$

Uma vez calculadas as projeções (ou, também conhecida como etapa de predição), é necessário corrigir o valor de $\widehat{x}$ segundo a comparação com leitura de um sensor real $y$ relativo aos estados que se deseja medir, de modo que $\widehat{x} \rightarrow x$. Além disso, a covariância $P$ também deve ser corrigida, de tal maneira que $P \rightarrow 0$. Para tanto, há o cálculo do ganho ótimo $K$, que tem o papel de fazer a correção, tanto de $\widehat{x}$ quanto de $P$, denominado por ganho de Kalman. Esta é, portanto, a fase de correção:

$$
K_{k}=P_{k \mid k-1} C^{T}\left(C P_{k \mid k-1} C^{T}+R\right)^{-1}
$$

em que $\mathrm{R}$ é a covariância do ruído de medição do sensor $y$.

Atualização (ou, correção) da estimativa de estados:

$$
\hat{x}_{k \mid k}=\hat{x}_{k \mid k-1}+K_{k}\left(y_{k}-C \hat{x}_{k \mid k-1}\right)
$$


Atualização (a posteriori) da matriz de covariância:

$$
P_{k \mid k}=\left(I-K_{k} C\right) P_{k \mid k-1}
$$

No filtro de Kalman, o sistema $x$ e o sensor $y$ são contaminados por ruídos, e o ganho de Kalman conduz uma estimativa $\widehat{x}$, que é um modelo matemático dado pela esperança de $x$, diretamente para onde os estados $x$ estão no momento. Como consequência, o espalhamento (covariância) entre $x$ e $\widehat{x}$, dado pela matriz $P$, tende a zero, uma vez que $\widehat{x} \rightarrow x$.

Resumidamente, quando se faz necessária a estimativa de valores e a mensuração destes valores contém incertezas, erros ou variações aleatórias, o filtro de Kalman se mostra como uma ferramenta de extrema importância. Pois, através de um processo matemático iterativo que utiliza um conjunto de equações, juntamente com dados de entrada recebidos pelo sistema, é possível estimar a grandeza desejada.

Neste trabalho, os filtros descritos (passa-baixa FIR, IIR, média móvel e Kalman) serão utilizados para reduzir os ruídos produzidos pela Rede Neural nos dados preditos por sua saída. Como a rede é recorrente, os ruídos são realimentados na rede e se acumulam, fazendo com que a rede divirja com o passar do tempo. Como a proposta é preservar as tendências dos dados ao invés de uma predição perfeita dos valores do CMO/PLD, a filtragem ajuda a eliminar principalmente os ruídos de alta frequência que venham a ser produzidos pela rede. Os filtros serão testados de modo a revelar qual tem melhores condições de ajudar a preservação da tendência de preços ao longo do ano. 


\section{METODOLOGIA PROPOSTA}

Conforme apresentado no Capítulo 2, as Redes Neurais Artificiais têm sido amplamente utilizadas para a predição dos preços no mercado de curto prazo. Neste sentido, o presente trabalho visa verificar um modelo de predição do PLD para o submercado Sudeste/Centro Oeste. Qualquer submercado poderia ter sido escolhido, uma vez que seus comportamentos são semelhantes, conforme pode-se verificar na Figura 3.1. Este capítulo apresenta a metodologia proposta, incluindo a escolha dos dados de entrada, do método de treinamento da RNA, e o processamento dos dados de entrada e de saída.

Figura 3.1 - PLD médio de todos os submercados.

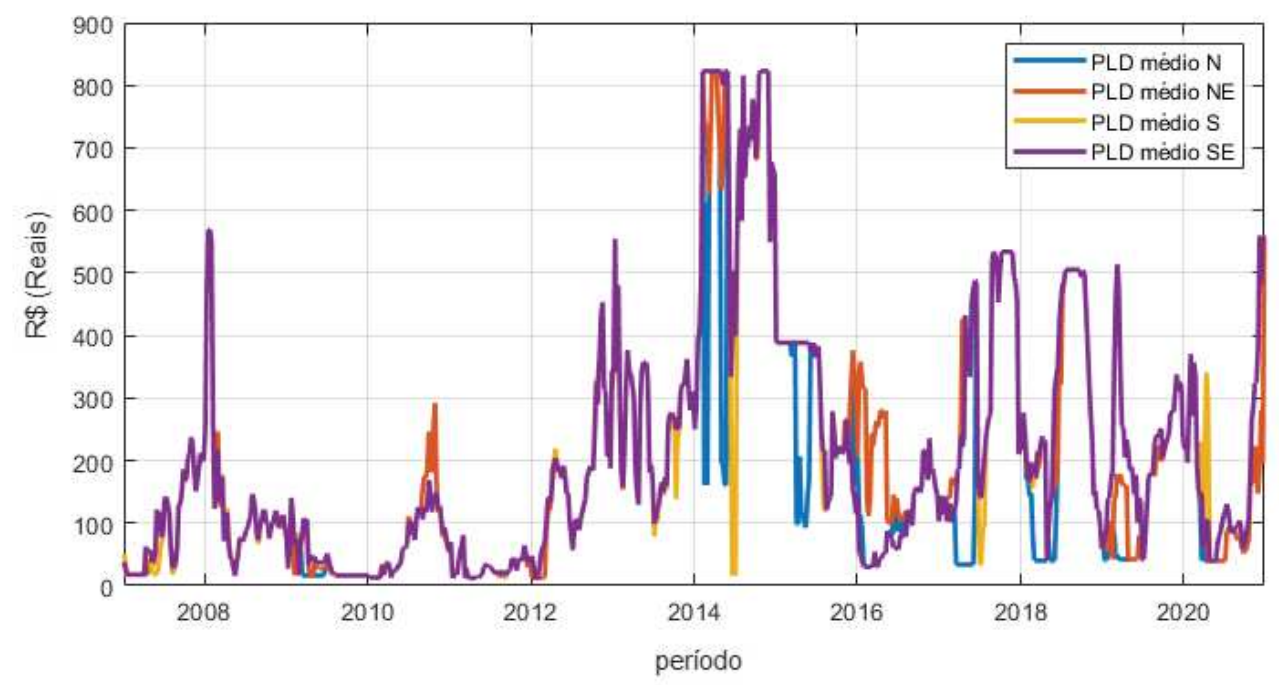

Fonte: (CCEE, 2021b).

\subsection{Escolha dos Dados de Entrada}

Como mencionado no Capítulo 1, o valor do PLD e do CMO são fortemente semelhantes, sendo a diferença entre eles dada pela saturação imposta pelos preços mínimo e máximo estipulados anualmente pela ANEEL para o PLD. Tendo em vista que essas restrições ao PLD provocam perda de informação dos dados, optou-se por arquitetar uma Rede Neural que predissesse o valor do CMO, para então poder restringi-lo com os limites máximo e mínimo, obtendo-se, assim, uma boa estimativa para a tendência de comportamento do PLD.

Uma primeira abordagem consiste em alimentar as entradas da rede recorrente com os dados do CMO e avaliar se, por não serem saturados, estes dados auxiliam na predição de várias semanas a frente. A seguir, serão investigadas outras variáveis que compõem o cálculo do PLD. A escolha destas variáveis será feita a partir da correlação entre o CMO e 
todas as variáveis selecionadas. As variáveis que apresentarem maiores correlações irão compor a entrada da RNA, além das próprias realimentações desta rede.

Desta forma, foram utilizadas como entradas da RNA combinações das variáveis divulgadas no histórico do ONS (ONS, 2020) e CCEE (CCEE, 2021b), sendo elas, Carga de Energia (CE), Demanda Máxima (DM), Energia Armazenada (EA), Energia Natural Afluente (ENA), Geração de Energia (GE), Intercambio de Energia (IE), Preço de Liquidação das Diferenças (PLD), e Custo Marginal de Operação (CMO).

A configuração da entrada da RNA, envolvendo as variáveis anteriores, é apresentada na equação (3.1), com discretização semanal, onde $t$ é o índice da semana relativa à saída da rede (semana que se quer predizer); $n_{p}$ é o número de atrasos temporais das entradas, a ser escolhido por meio da análise de correlação entre o CMO e as outras variáveis da ONS; y é a saída da Rede Neural (que pode ser filtrada ou não); e $n_{q}$ é o número de atrasos TDNN Time Delay Neural Network da saída, em que $n_{q} \leq n_{p}$.

$$
\text { Entradas RNA }=\left[\begin{array}{c}
C M O(t-1) \\
\vdots \\
C M O\left(t-n_{p}\right) \\
E N A(t-1) \\
\vdots \\
E N A\left(t-n_{p}\right) \\
D M(t-1) \\
\vdots \\
D M\left(t-n_{p}\right) \\
\vdots \\
\text { Variáveis ONS } \\
\vdots \\
y(t-1) \\
\vdots \\
y\left(t-n_{q}\right)
\end{array}\right]
$$

Por se tratarem de dados estocásticos, contaminados por ruídos aleatórios, propõese uma etapa de filtragem na saída da RNA para alisamento dos dados, objetivando uma melhor qualidade da predição devido à redução da influência de ruídos e à redução da volatilidade dos dados de entrada da Rede Neural.

O processo de filtragem ocorre mediante transformações matemáticas nas séries temporais, possibilitando uma limpeza nos componentes de altas frequências da série. Optou-se pela implementação e análise dos filtros Passa-Baixa (FIR e IIR), Média Móvel e Filtro de Kalman com a perspectiva de redução de ruídos e consequente prolongamento 
da qualidade de tendências de predição. A Figura 3.2 apresenta a arquitetura de rede proposta com a inserção da etapa de filtragem antes da realimentação dos dados.

\subsection{Escolha do Método de Treinamento}

Conforme citado no subitem 2.4.2, existem vários métodos de treinamento de uma Rede Neural Artificial, e cada um deles promove um efeito diferente no treinamento e posterior predição da RNA. No sentido de avançar no entendimento dos métodos de treinamento mais comumente utilizados e então escolher um bom otimizador para a RNA proposta, foi feita a predição de uma série temporal previamente conhecida, contaminada por um ruído Gaussiano, utilizando cinco opções de otimizadores, a saber:

\section{i Backpropagation original;}

ii Backpropagation com Momentum;

iii Resilient Backpropagation;

iv Levenberg-Marquardt, e;

v $A D A M$.

Figura 3.2 - Rede com filtragem antes da realimentação.

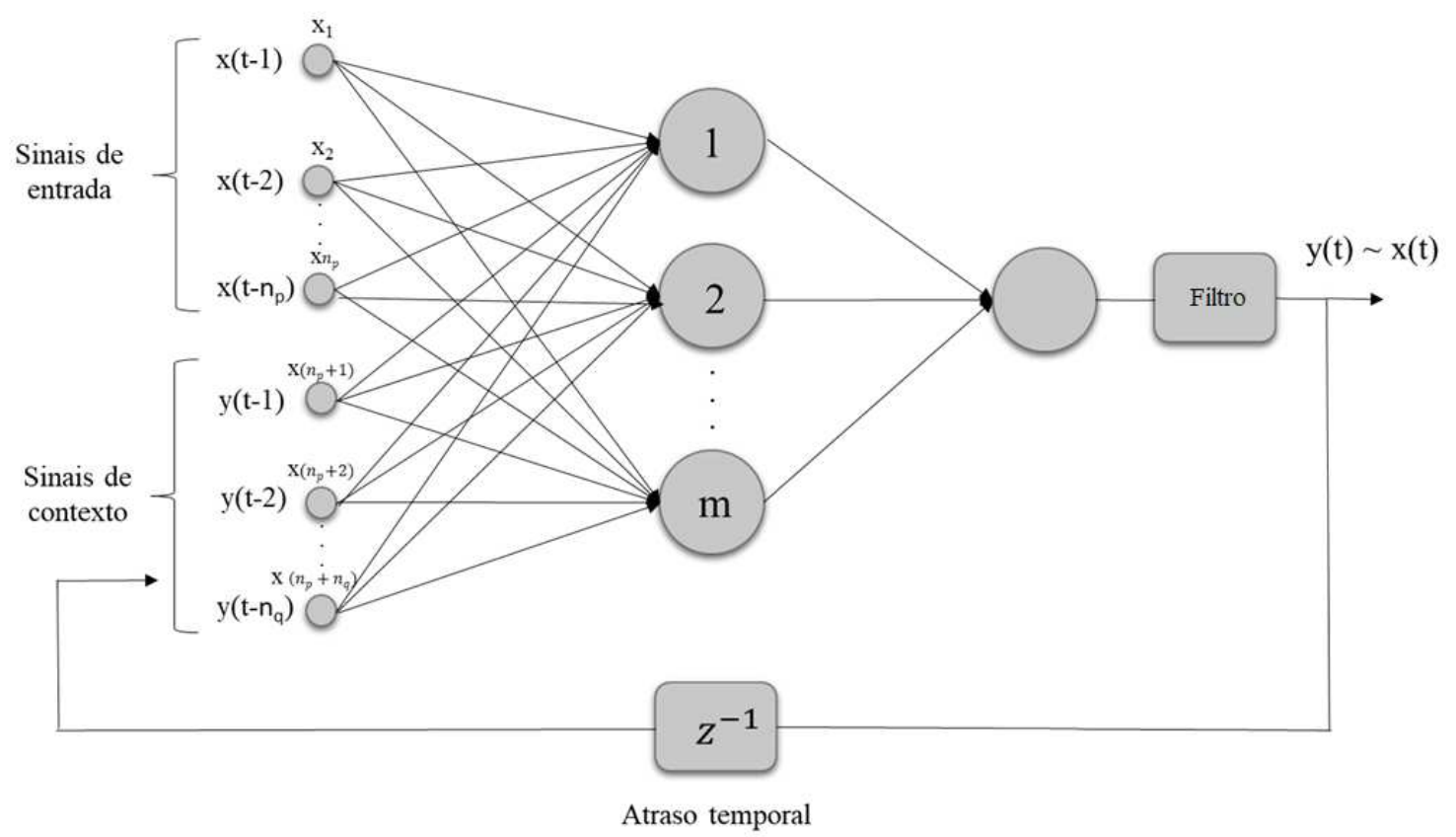

A proposta é comparar os otimizadores anteriormente listados utilizando sinais bem conhecidos, para avaliar seus desempenhos, tanto na predição quanto no tempo de convergência na presença de ruído. A Figura 3.3 apresenta os resultados destes otimizadores. Vale ressaltar que todos os otimizadores partiram dos exatos mesmos pesos sinápticos 
iniciais, com o mesmo número de neurônios, e todos os demais parâmetros idênticos. Todos os otimizadores foram implementados pela autora, sem o uso de ferramentas prontas.

Figura 3.3 - Convergência dos algoritmos de treinamento.

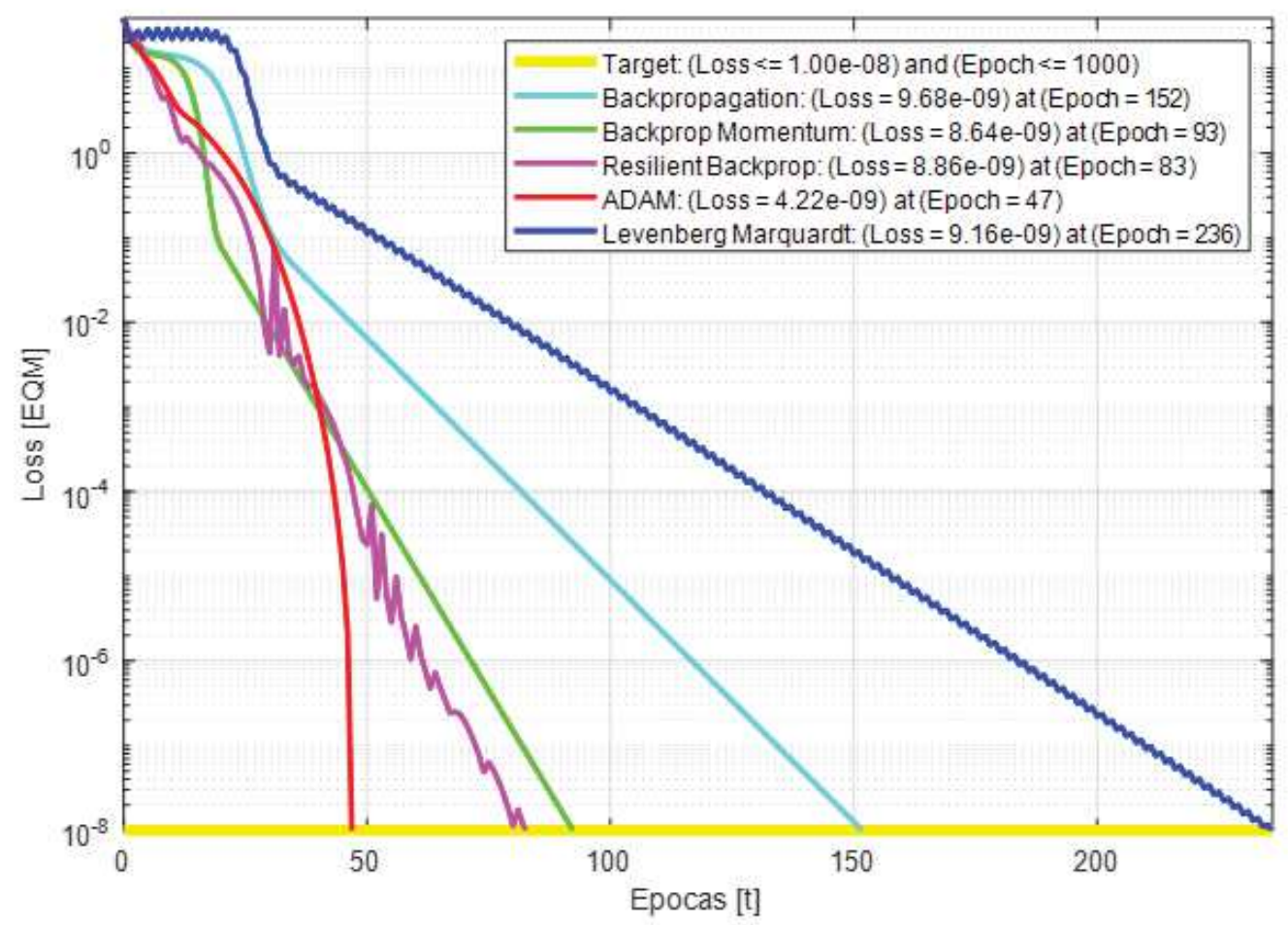

Nota-se, por inspeção visual, que o método ADAM (P.KINGMA; BA, 2014) converge rapidamente e, principalmente, sem demonstrar as mesmas oscilações do segundo colocado, o Resilient Backpropagation. Desta maneira, é possível confirmar, levando em consideração o afirmado no artigo dos autores, que o método $A D A M$ é mais bem adaptado para lidar com séries temporais, especialmente as contaminadas por ruídos aleatórios, sendo um método de otimização estocástica.

O $A D A M$ é bem adaptado para ruídos por suas propriedades inerentemente estatísticas de treinamento, uma vez que o $A D A M$ utiliza tanto a Esperança Estatística (primeiro momento estatístico), quanto a Variância (segundo momento estatístico), para atualizar os pesos sinápticos da RNA. Isso faz com que esses pesos convirjam rapidamente, com o efeito de Momentum, para a média dos dados, com baixo desvio padrão, tornando-o um dos métodos mais bem-sucedidos da literatura em treinamento de Redes Neurais Artificiais (P.KINGMA; BA, 2014).

A seguir, nas Figuras 3.4, 3.5 e 3.6, estão apresentados os resultados de treinamento e predição para diferentes funções de teste, bem conhecidas, contaminadas por ruído, utilizadas para a avaliar a convergência dos algoritmos de treinamento. Em todas as Figuras, o sinal em "Vermelho" é a série original de treinamento, em "Verde" é a série 
original futura (o objetivo a ser alcançado), em "Preto" é o aprendizado da RNA e, finalmente, o sinal em "Azul"refere-se à predição da variável de interesse no futuro pela Rede Neural.

Figura 3.4 - Seno contaminado por ruído aleatório Gaussiano.
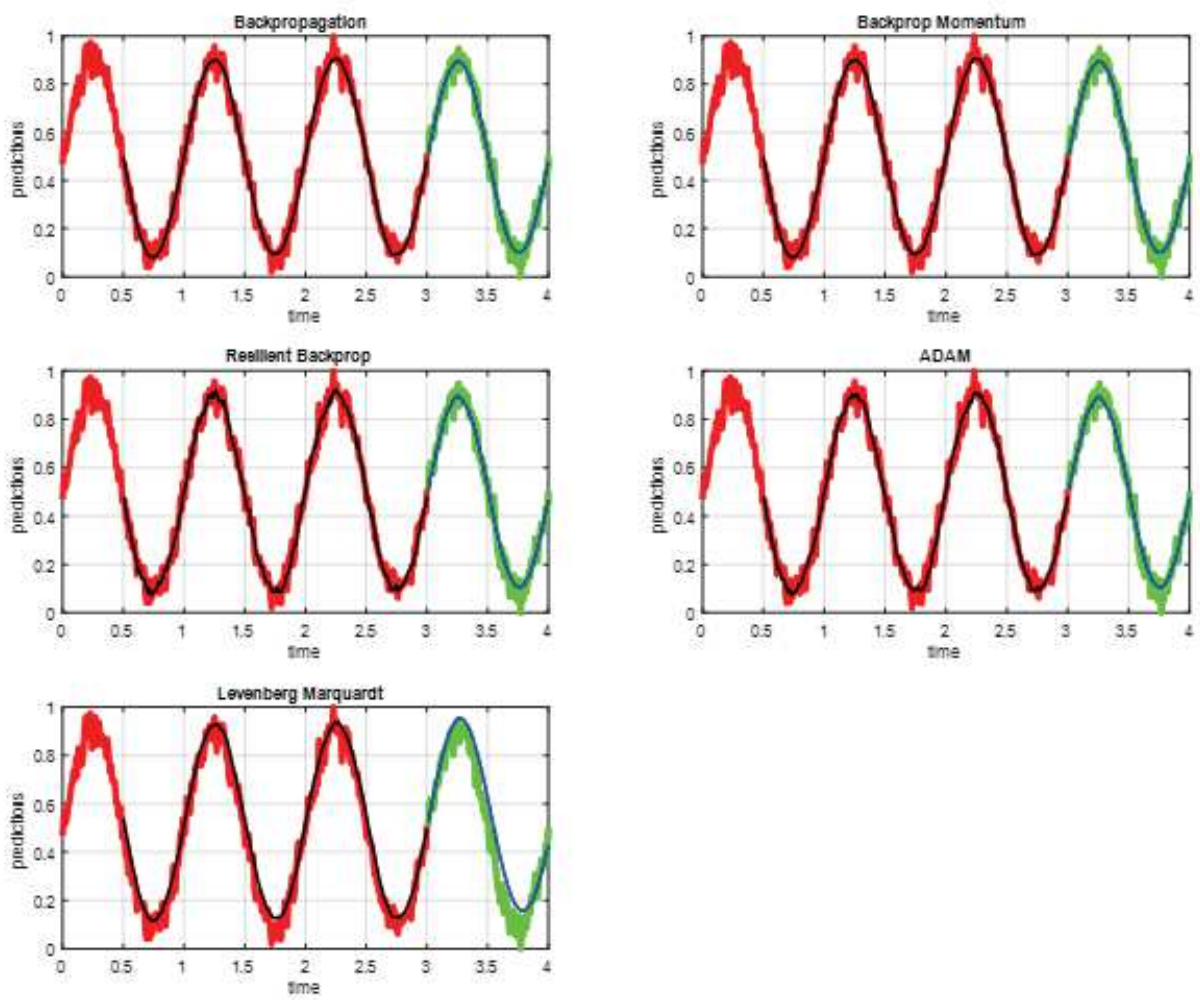

Nota-se que, para as funções de teste, que são periódicas, a RNA teve um bom desempenho no aprendizado e na predição. Ainda assim, é possível perceber pequenas diferenças entre os treinamentos e predições, em que os melhores colocados foram os métodos $A D A M$ e Resilient Backpropagation, tanto qualitativa quanto quantitativamente.

Considerando que o método $A D A M$ é mais rápido e mais suave em sua convergência, este será o método adotado a ser aplicado no aprendizado e na predição do CMO para tempos futuros. Esse algoritmo, especializado em séries estocásticas, ou seja, contaminadas por ruídos aleatórios, utiliza uma variação do Backpropagation, baseado no cálculo de momentos, que é, de fato, a combinação das vantagens de outros dois algoritmos, o AdaGrad e o RMSProp. O ADAM utiliza taxas de aprendizado individuais adaptativas para o primeiro e o segundo momentos do gradiente, momentos estes estimados via média móvel, e faz também uma correção de viés de inicialização (P.KINGMA; BA, 2014).

O sistema elétrico brasileiro possui suas variáveis fortemente contaminadas por fatores aleatórios, como o clima, chuvas, disponibilidades de geração, demandas repentinas, dentre outras. Conforme desempenho dos otimizadores para dados na presença de ruídos, o 
Figura 3.5 - Exponencial negativa multiplicada por seno.
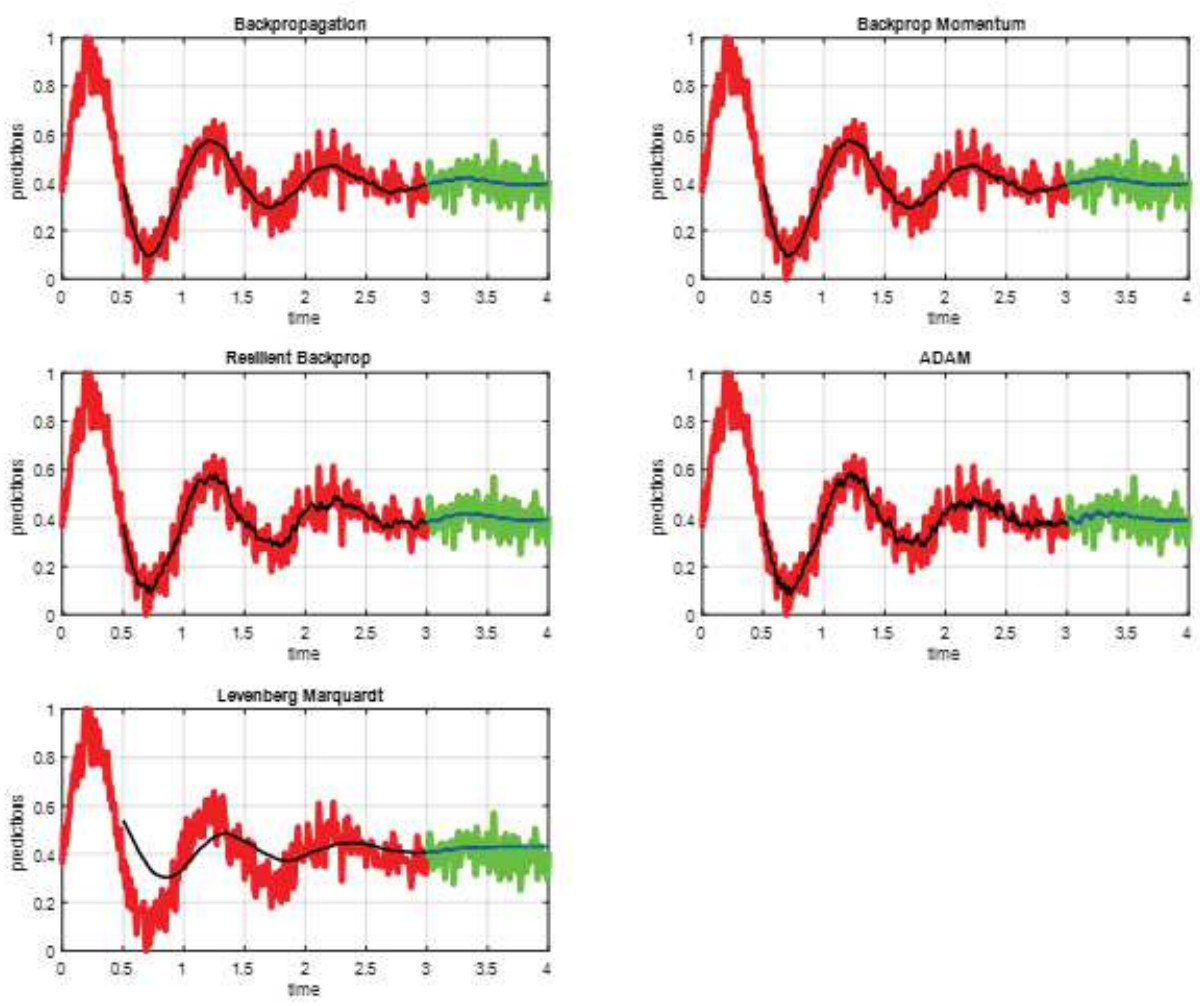

Figura 3.6 - Composição de senoides de diferentes frequências.
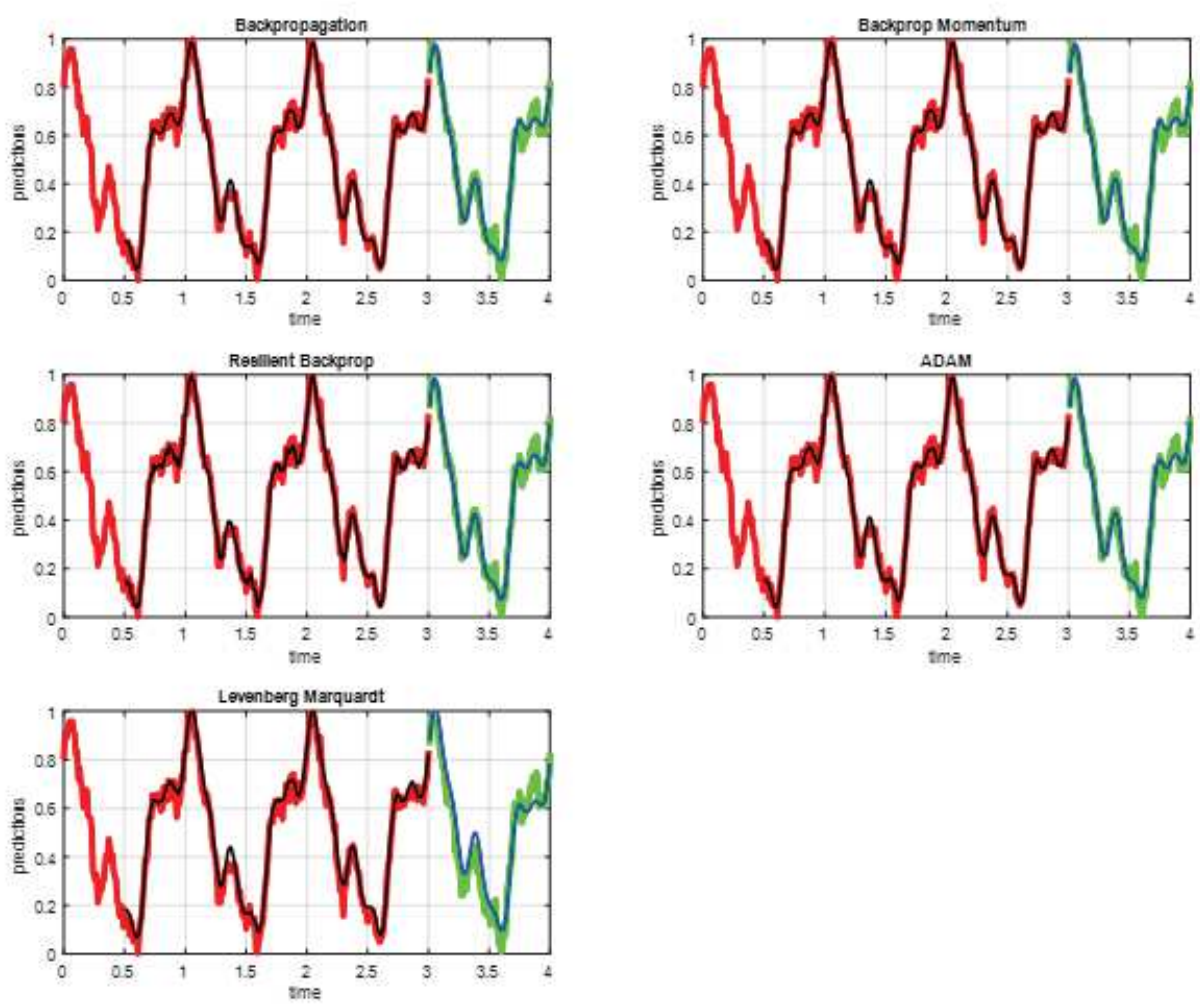
$A D A M$ torna-se a escolha mais bem adaptada para o objeto de pesquisa desta dissertação. Suas vantagens incluem, ainda, um bom resultado com dados ruidosos e gradientes escassos (problema enfrentado principalmente por redes recorrentes), pouca necessidade de ajuste de parâmetros e uma melhor eficiência computacional.

\subsection{Processamento das Variáveis}

Para desenvolver os modelos de predição dos preços e tendências do PLD, a base de dados utilizada foi obtida na Câmara de Comercialização de Energia Elétrica (CCEE) e do Operador Nacional do Sistema Elétrico (ONS), e abrange da primeira semana operativa de 2007 até a última semana operativa de 2020, totalizando 730 semanas. As variáveis que compõem a base de dados de entrada foram a Energia Armazenada (EA), Demanda Máxima (DM), Carga de Energia (CE), Geração de Energia (GE), Energia Natural Afluente (ENA) e Intercâmbios de Energia (IE), além das próprias séries históricas dos valores do Preço de Liquidação das Diferenças (PLD) e Custo Marginal de Operação (CMO). Os dados contidos na base se referem ao submercado Sudeste/Centro Oeste. O comportamento das variáveis componentes do banco de dados está representado nas Figuras 3.7 e 3.8, que demonstram o comportamento das mesmas para o período de tempo escolhido.

Figura 3.7 - Séries de dados da ONS e suas unidades: CE [MWmed], DM [MWh/h], EA [MWmês], ENA [MWmed], GE [MWmed] e IE [MWmed].

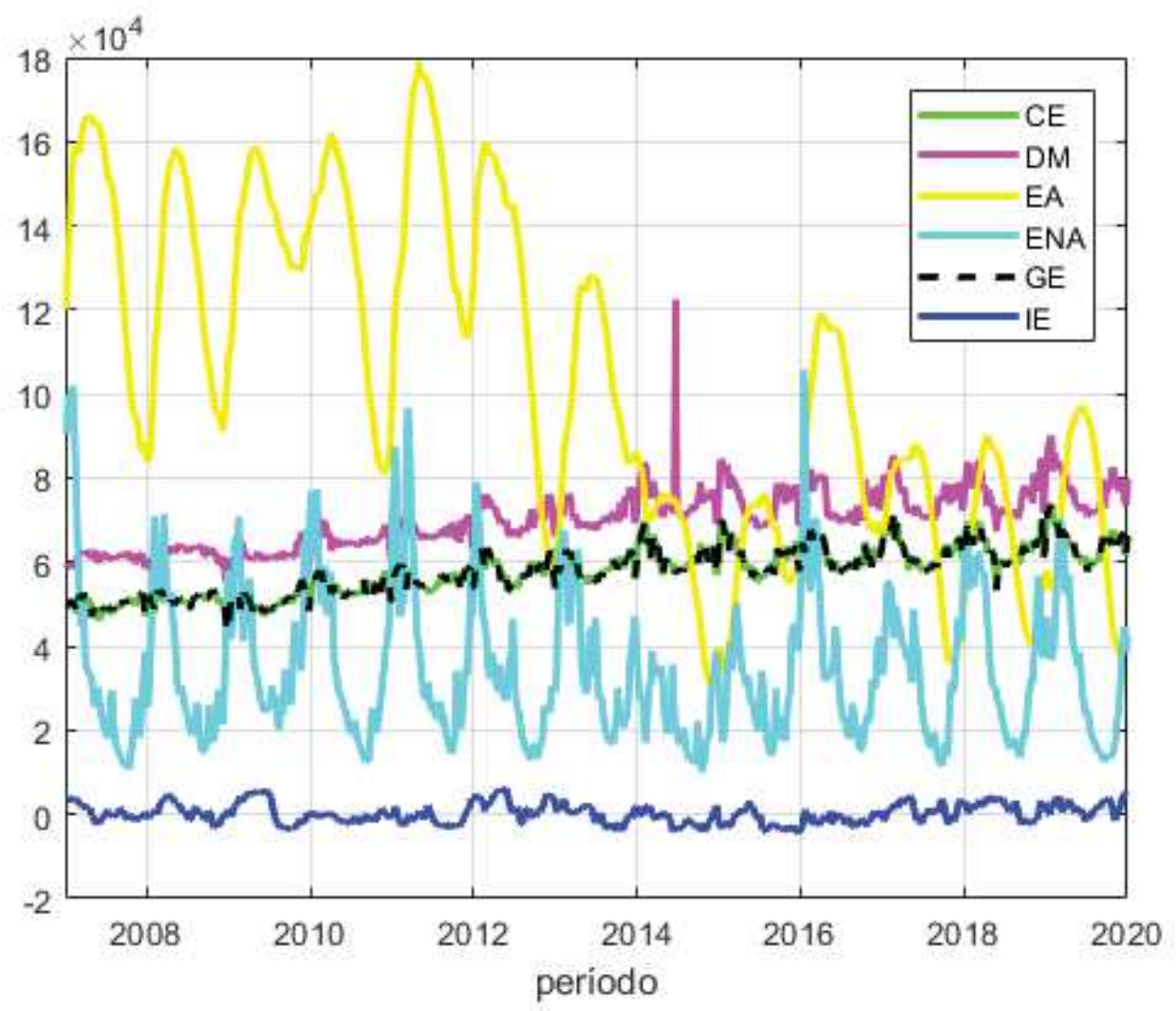

Fonte: (ONS, 2020). 
Pode-se observar que as variáveis, sujeitas a sazonalidade das estações, apresentam volatilidade e incertezas. Esta forte volatilidade se deve à influência constante de variáveis exógenas como chuvas, clima, disponibilidades de geração, demandas repentinas, dentre diversas outras. Ainda assim, quando comparadas com o CMO/PLD, possuem um comportamento mais propício a predições, uma vez que se verifica, por inspeção visual da Figura 3.7 que existem estruturas periódicas nestas variáveis. Estruturas periódicas produzem altas correlações cruzadas, favorecendo algoritmos de aprendizado como Redes Neurais, que capturam essas tendências para predizer acuradamente comportamentos futuros.

Figura 3.8 - Série de dados - CMO e PLD.

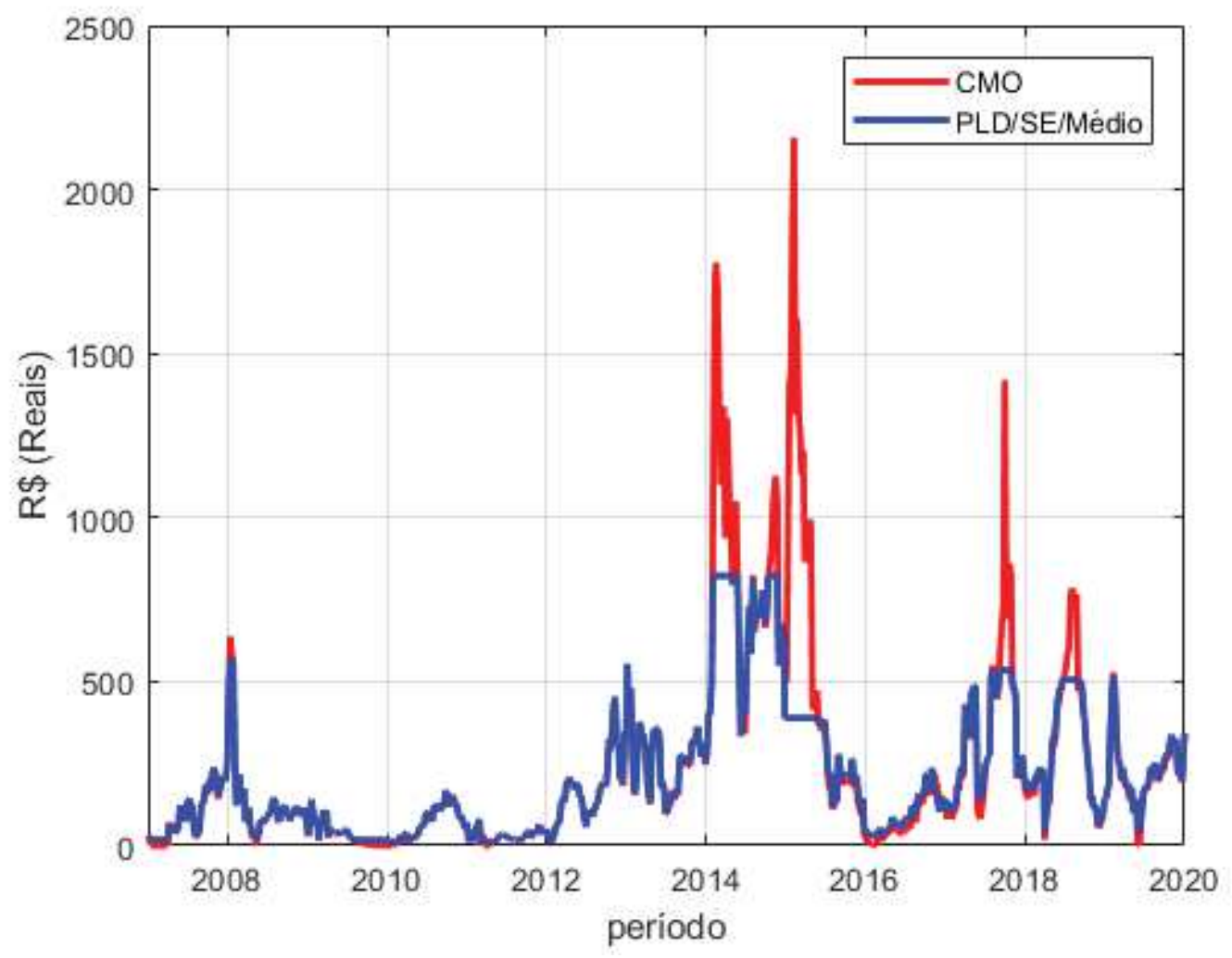

Fonte: (ONS, 2020) e (CCEE, 2021d).

Primeiramente, as variáveis foram conduzidas a um pré-processamento, objetivando realizar um ajuste de base temporal e compensar dados faltantes para todas. Os poucos dados faltantes foram estimados por meio de interpolação linear entre o dado imediatamente anterior e posterior da série em ordem cronológica. É de suma importância que todas as séries de dados históricos estejam na mesma base temporal e compostas pelo mesmo número de elementos, a fim de que eventuais descompassos temporais entre as variáveis não acarretem erros de predição.

Após serem processados e completados, os dados são normalizados no intervalo $[0,1]$. Esta etapa consiste no escalonamento das amostras para a faixa de variação dinâmica 
da função de ativação. Desta forma, os valores das entradas são mantidos em um intervalo condizente com os principais teoremas de convergência, e respeita os limites das principais funções de ativação utilizadas em Redes Neurais, evitando a saturação da saída do neurônio quando os potenciais de ativação apresentarem valores elevados.

Diversas funções de ativação foram experimentadas, como a tangente hiperbólica, logística, ReLU, Softplus e exponencial. Após diversos testes, a função de ativação escolhida para a Rede Neural deste trabalho é a ReLU (Rectified Linear Unit). Um neurônio com uma função de ativação ReLU assume quaisquer valores reais como sua(s) entrada(s), mas só é ativado quando essas entradas são maiores que 0. A função e sua derivada estão representadas nas Equações 3.2 e 3.3 e representadas graficamente na Figura 3.9.

$$
\begin{gathered}
\operatorname{Re} L U(x)=\max \{0, x\} \\
\operatorname{ReLU}^{\prime}(x)=\left\{\begin{array}{lll}
1 & 1 & \text { se } x \geq 0 \\
0 & \text { c.c }
\end{array}\right\}
\end{gathered}
$$

Figura 3.9 - Função ReLU e sua derivada.

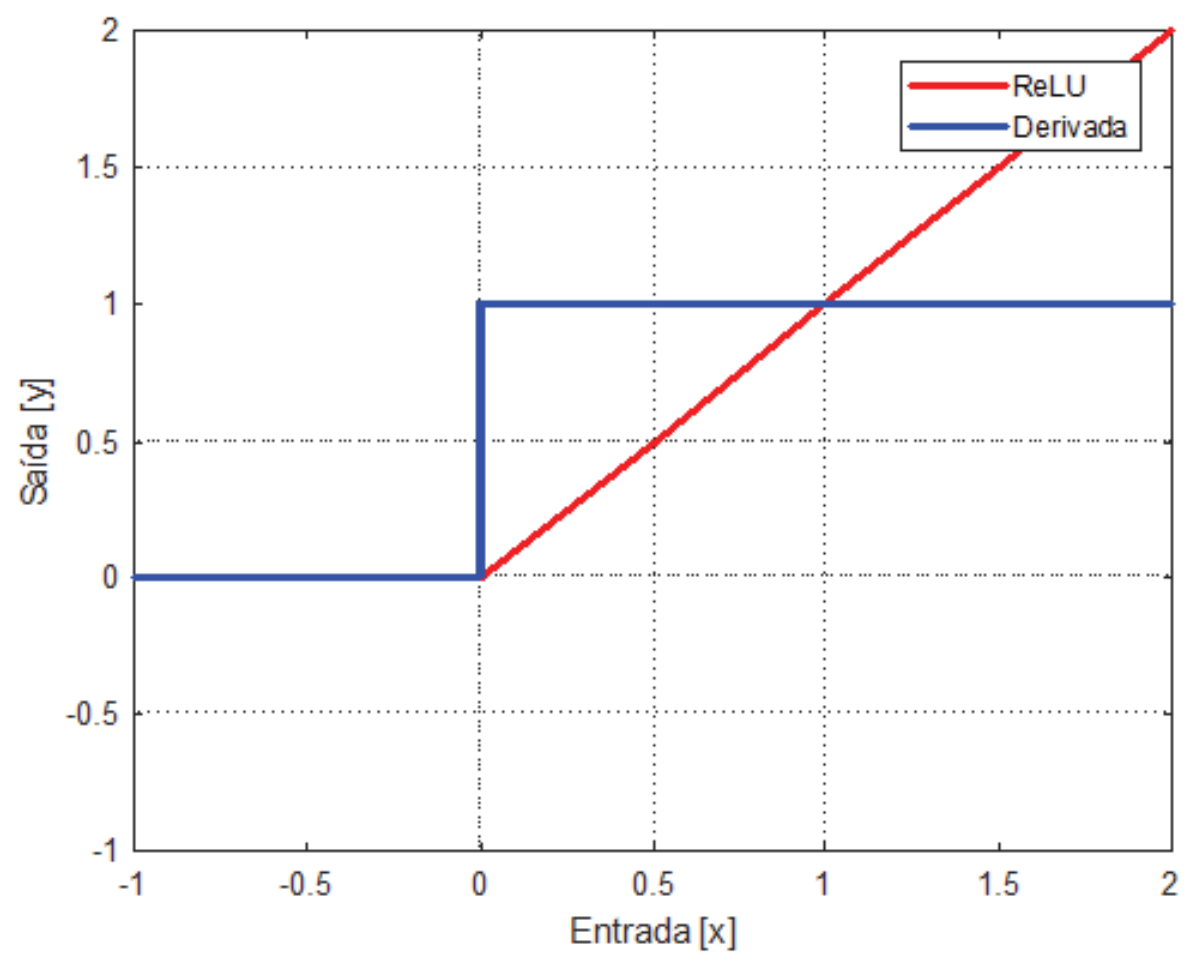

A ReLU é a função de ativação mais utilizada nos projetos de Redes Neurais modernos (ACADEMY, 2019). Ela mantém a linearidade desejada na parte positiva, e insere a não linearidade na parte negativa, permitindo um treinamento mais rápido e efetivo de arquiteturas mais profundas em extensos e complexos conjuntos de dados, 
por não fazer uso de expoentes, realizando apenas operações de comparação, adição e multiplicação. De forma a evitar as regiões de saturação da função ReLU, optou-se por normalizar os dados no intervalo de 0 a 1. A Equação 3.4 demonstra como é feita a normalização dos dados, por meio de uma relação linear:

$$
d a t a_{n o r m}=\max _{\text {norm }}-\frac{\left(\max _{\text {norm }}-\min _{\text {norm }}\right)\left(\max _{\text {data }}-\text { data }\right)}{\max _{\text {data }}-\min _{\text {data }}}
$$

Na Equação 3.4, data é o conjunto de treinamento, no caso, a série temporal representada pelos valores das variáveis disponibilizadas pela CCEE e ONS, os quais se deseja aprender com a rede; data $a_{\text {norm }}$ é a função de treinamento normalizada; max $_{\text {norm }}$ é o valor máximo permitido para a normalização e min $_{\text {norm }}$ é o respectivo valor mínimo permitido, então $d a t a_{\text {norm }}$ está contido no intervalo [ $\left.\max _{\text {norm }}, \min _{\text {norm }}\right]$; equitativamente, $\max _{\text {data }}$ é o valor máximo permitido para a série temporal e $\min _{\text {data }}$ o respectivo valor mínimo.

Após a normalização, o conjunto de dados (14 anos de operação do sistema) foi dividido, sendo as 677 primeiras semanas (13 anos) para treinamento $(92,74 \%)$ e as 53 últimas para validação (7,26\%), o que corresponde ao ano de 2020. O conjunto de treinamento é responsável pelo aprendizado da rede e ajuste dos pesos sinápticos. O segundo conjunto é utilizado para avaliar o desempenho de generalização da rede.

Os dados de treinamento, composto pelo conjunto das entradas e saídas desejadas é obtido a partir dos dados normalizados. Tendo em vista a topologia representada na Figura 2.4, no primeiro instante a rede recorrente faz uso dos sinais de entrada (composto por uma combinação de variáveis) atrasadas no tempo em conjunto com os sinais de contexto iguais a zero, uma vez que a saída inexiste no momento. No instante posterior, o primeiro valor produzido pela saída da rede estará disponível e pode realimentar uma entrada da rede, enquanto as demais ainda são zero. Sucessivamente, os próximos instantes das saídas estarão disponíveis e serão introduzidas nas entradas. O conjunto de treinamento é construído com a repetição do processo descrito para todos os instantes posteriores.

Conforme demonstrado na seção 3.2, após a realização de testes com algoritmos de treinamento mais comumente utilizados na literatura, optou-se por implementar o $A D A M$, que é um algoritmo de treinamento com boa adaptação para dados estocásticos, além da sua atrativa velocidade de convergência. O aprendizado da rede é feito de forma supervisionada, mediante a apresentação do conjunto dos dados de entrada e os desejados de saída. De forma iterativa, à medida em que a rede recebe as entradas, os resultados da saída são comparados com as saídas desejadas.

O processo de treinamento é utilizado até que a resposta atenda às condições de parada. Posteriormente, os dados são generalizados e preditos para quantos passos no futuro sejam desejados. A rede autorregressiva, realimentada com a saída filtrada da mesma tem o propósito de generalizar as tendências dos dados-objetivo, no caso, do CMO. 
Isto significa que a missão não é predizer o preço futuro do CMO com total acurácia, e sim, capturar seu comportamento geral, de tal maneira que um analista possa utilizar esta informação para decidir qual o melhor momento para gerar contratos de compra e venda de energia. 


\section{RESULTADOS E ANÁLISES}

Este capítulo apresenta os resultados obtidos com a aplicação dos métodos propostos para a predição do CMO e posterior análise do comportamento do PLD aplicados à base de dados disponibilizada pela CCEE. Além do desempenho da rede recorrente, será explorada a combinação de filtros à RNA. Para a consecução da pesquisa, todo o desenvolvimento e análise foram conduzidos através do software Matlab (MATHWORKS, 2021).

Toda a implementação dos resultados apresentados, envolvendo a RNA, análises estatísticas e o processamento foi realizada pela autora no âmbito da presente dissertação, sem a utilização de pacotes prontos. O desempenho de predição dos modelos implementados será avaliado retendo alguns dados da amostra para, em seguida, utilizar o modelo para fazer predições para os dados de validação, a fim de ver o quão precisos eles são.

A estatística de erro utilizada tem como base a raiz quadrada do erro quadrático médio (Root Mean Squared Error, RMSE), que conforme descrito por (MEDIUM, 2016), é uma das métricas mais utilizadas para medir a acurácia de modelos preditivos e, de fato, uma das mais utilizadas na literatura em função de sua propriedade estatística, embora existam outras. O fato interessante é ela ter a mesma unidade, no caso, Reais ( $\mathrm{R} \$ / \mathrm{MWh}$ ), da variável de interesse. A partir dela é possível avaliar o desempenho da Rede Neural, possibilitando a escolha da melhor configuração. Nesta métrica, os dados preditos pela rede, após treinada, são comparados com um conjunto de dados que não está presente no processo de treinamento, gerando os erros de predição a partir da Equação 4.1:

$$
R M S E=\sqrt{\frac{1}{n} \sum_{i=1}^{n}\left|P_{i}-Q_{i}\right|^{2}}
$$

em que $n$ é o número de amostras no conjunto, $P_{i}$ e $Q_{i}$ são os i-ésimos valores desejado e obtido pela RNA, respectivamente.

A qualidade do treinamento da Rede Neural Artificial está relacionada diretamente com a definição de determinados parâmetros. Foram realizados diversos testes empíricos para a definição de alguns parâmetros e, a partir destes testes, foram fixados os que apresentaram melhor desempenho para a RNA na capacidade de aprendizagem e predição. É necessário fixar alguns parâmetros para evitar que o universo de busca se torne muito extenso. Em relação ao método de treinamento $A D A M$, foram fixadas as taxas de aprendizado do primeiro e segundo momento, $\beta_{1}=0,5$ e $\beta_{2}=0,95$, bem como o valor da taxa de aprendizado por época $\alpha=0,01 / \sqrt{t}$ e $\epsilon=1 \times 10^{-8}$.

O critério de parada do treinamento foi limitado em $1 \times 10^{-9}$. Ou seja, o algoritmo converge quando o erro calculado em função do RMSE atinge a precisão requerida. Em conjunto com o erro, utilizou-se a contabilização do número de épocas necessárias para a efetivação do treinamento da RNA. Este parâmetro não pode ser pequeno, de forma que a Rede Neural Artificial não consiga aprender adequadamente, e nem elevado 
demasiadamente para não provocar overtraining, condição em que a rede memoriza os padrões fornecidos, tornando-se incapaz de generalização. Constatou-se que a RNA produz respostas com qualidade quando treinada em até 150 épocas $\left(t_{\max }=150\right)$.

A seguir apresentam-se os resultados para diferentes situações, em que a inserção de cada uma das várias estratégias será gradual, para que seus efeitos possam ser analisados frente a um histórico evolutivo, partindo das implementações mais simples.

\subsection{CMO como única variável de entrada}

Esta seção apresenta os resultados obtidos para a predição do CMO para o submercado Sudeste/Centro-Oeste, utilizando apenas o próprio histórico do CMO como entrada da RNA. Serão aplicadas duas metodologias para explorar a capacidade de predição da Rede Neural Recorrente. A primeira metodologia refere-se à abordagem clássica e consiste na utilização da RNA para a predição do futuro a um passo, ou seja, a rede preverá apenas o valor do CMO uma semana à frente. Na segunda abordagem, tem-se a predição de vários passos no futuro, no caso, um ano inteiro à frente, correspondente ao ano de 2020.

Com os parâmetros fixos definidos nas seções anteriores, foram testadas diversas configurações de topologias de rede, objetivando encontrar as topologias que permitam uma melhor generalização dos dados. Os testes foram feitos variando o número de camadas escondidas, bem como o número de neurônios pertencentes a cada camada. Outro parâmetro alterado foi o número de entradas atrasadas no tempo e o número de saídas realimentadas como entrada da rede. A escolha de tais parâmetros influencia o treinamento e a convergência da RNA, podendo causar, inclusive, a divergência da mesma.

\subsubsection{Predição de um passo no futuro}

Nesta primeira abordagem, foram simuladas 16 configurações diferentes de RNAs, com variações tanto no número de camadas escondidas quanto no número neurônios por camada além das alterações no número de atrasos das entradas e realimentações da saída, que variaram entre 2, 10, 20 e 30. A razão das escolhas desta faixa de valores para os atrasos em específico foram, inicialmente, por busca empírica com base em trabalhos anteriores (NASCIMENTO, 2017), (NASCIMENTO; OLIVI; LIMA, 2018) e (NASCIMENTO et al., 2019), porém, após a análise estatística apresentada, em breve, na Seção 4.2, este intervalo se consolidou como o melhor, tanto em função da correlação cruzada entre as séries temporais quanto pela reduzida quantidade de dados disponíveis.

A Tabela 4.1 mostra as configurações e resultados das RNAs simuladas, em que $N_{1}, N_{2}$ e $N_{3}$ correspondem ao número de neurônios na primeira, segunda e terceira camada oculta, respectivamente, $n_{p}$ é o número de atrasos da entrada e $n_{q}$ é o número de realimentações das saídas. 
Tabela 4.1 - Resultados por topologia - 1 passo no futuro

\begin{tabular}{|c|c|c|c|c|c|c|c|c|c|}
\hline \multicolumn{4}{|c|}{ Configurações da rede } & \multicolumn{3}{|c|}{ Treinamento } & \multicolumn{3}{|c|}{ Validação } \\
\hline$N_{1}$ & $\mathrm{~N}_{2}$ & $N_{3}$ & $\begin{array}{c}n_{p} \mathbf{e} \\
n_{q}\end{array}$ & $\begin{array}{c}\text { Erro } \\
\text { Quadrático } \\
\text { Médio }(\mathrm{R} \$)^{2}\end{array}$ & $\begin{array}{l}\text { Erro } \\
\text { Médio } \\
(\mathbf{R} \$)\end{array}$ & $\begin{array}{l}\text { Desvio } \\
\text { Padrão }\end{array}$ & $\begin{array}{c}\text { Erro } \\
\text { Quadrático } \\
\text { Médio }(\mathbf{R} \$)^{2}\end{array}$ & $\begin{array}{l}\text { Erro } \\
\text { Médio } \\
(\mathbf{R} \$)\end{array}$ & $\begin{array}{l}\text { Desvio } \\
\text { Padrão }\end{array}$ \\
\hline \multirow{4}{*}{10} & \multirow{4}{*}{$\mathrm{x}$} & \multirow{4}{*}{$\mathrm{x}$} & 2 & 6,7161 & 2,5916 & 10,9769 & 4,9243 & 2,2191 & 10,1995 \\
\hline & & & 10 & 6,5275 & 2,5549 & 10,8980 & 4,6885 & 2,1653 & 10,0727 \\
\hline & & & 20 & 6,6016 & 2,5694 & 10,9300 & 4,9591 & 2,2269 & 10,2033 \\
\hline & & & 30 & 6,9219 & 2,6310 & 11,0538 & 5,0530 & 2,2479 & 10,2648 \\
\hline \multirow{4}{*}{20} & \multirow{4}{*}{20} & \multirow{4}{*}{$\mathrm{x}$} & 2 & 4,8229 & 2,1961 & 10,0945 & 4,1018 & 2,0253 & 9,7458 \\
\hline & & & 10 & 4,7187 & 2,1723 & 10,0341 & 3,8761 & 1,9688 & 9.6070 \\
\hline & & & 20 & 4,6690 & 2,1608 & 10,0030 & 3,9083 & 1,9769 & 9,6270 \\
\hline & & & 30 & 4,9923 & 2,2344 & 10,1628 & 3,9810 & 1,9952 & 9,6693 \\
\hline \multirow{4}{*}{10} & \multirow{4}{*}{20} & \multirow{4}{*}{15} & 2 & 4,7439 & 2,1780 & 10,0599 & 4,1041 & 2,0259 & 9,7479 \\
\hline & & & 10 & 4,6275 & 2,1512 & 10,0008 & 3,9436 & 1,9858 & 9,6460 \\
\hline & & & 20 & 4,6750 & 2,1622 & 10,0111 & 3,9332 & 1,9832 & 9,6435 \\
\hline & & & 30 & 4,8478 & 2,2018 & 10,0983 & 3,9614 & 1,9903 & 9,6588 \\
\hline \multirow{4}{*}{50} & \multirow{4}{*}{50} & \multirow{4}{*}{50} & 2 & 4,9478 & 2,2244 & 10,1688 & 4,2112 & 2,0521 & 9,7994 \\
\hline & & & 10 & 4,5841 & 2,1410 & 9,9595 & 3,9270 & 1,9817 & 9,6369 \\
\hline & & & 20 & 5,5472 & 2,3553 & 10,4646 & 4,3924 & 2,0958 & 9,9004 \\
\hline & & & 30 & 10,2907 & 3,2079 & 12.2130 & 6,7672 & 2,6014 & 11,0424 \\
\hline
\end{tabular}

Analisando os resultados apresentados na referida tabela é possível perceber que as redes configuradas com 10 e 20 atrasos TDNN nos dados do CMO de entrada $\left(n_{p}\right)$ e 10 e 20 realimentações da saída $\left(n_{q}\right)$ produzem bons resultados em todas as variações dos números de camadas e neurônios por camada, com um destaque maior para as topologias com duas camadas escondidas $\left(N_{1}=N_{2}=20\right)$ e 3 camadas escondidas $\left(N_{1}=10, N_{2}=20\right.$ e $\left.N_{3}=15\right)$ que apresentaram os melhores resultados globais. Os resultados de predição destas topologias são qualitativamente muito próximos e estão representados nas Figuras 4.1 e 4.2 para $N_{1}=N_{2}=20$ e nas Figuras 4.3 e 4.4 para $N_{1}=10, N_{2}=20$ e $N_{3}=15$.

Ao utilizar os atrasos da entrada e da realimentação da saída nos valores mínimo e máximo, ou seja, $n_{p}=n_{q}=2$ ou 30, a RNA apresenta os maiores erros para quaisquer configurações em relação ao número de camadas escondidas e número de neurônios por camada. A topologia com pior desempenho é representada pelas Figuras 4.5 e 4.6, com 50 neurônios nas camadas intermediárias $\left(N_{1}, N_{2}\right.$ e $\left.N_{3}\right), 30$ atrasos da entrada $\left(n_{p}\right)$ e 30 realimentações das saídas $\left(n_{q}\right)$. Nota-se que mesmo no pior resultado de predição, ainda assim a rede foi capaz de acompanhar a tendência dos dados, mostrando que apesar do erro ter sido o menos satisfatório, a rede incorporou o conhecimento da variação dos dados.

Tem-se que para as diferentes quantidades de neurônios nas camadas intermediárias, os melhores resultados de predição, independente dos valores assumidos por $n_{p}$ e $n_{q}$, são produzidos pela rede com 2 camadas escondidas $\left(N_{1}=N_{2}=20\right)$. Ao elevar o número de camadas, a rede com 3 camadas $\left(N_{1}=10, N_{2}=20\right.$ e $\left.N_{3}=15\right)$ produz resultados satisfatórios, mas ligeiramente piores quando comparados aos resultados da rede de duas camadas, evidenciando o comportamento altamente não-linear das Redes Neurais, em que não necessariamente a rede com maior número de neurônios terá melhor desempenho. 
Figura 4.1 - Predição para $N_{1}=N_{2}=20$ e $n_{p}=n_{q}=10$.

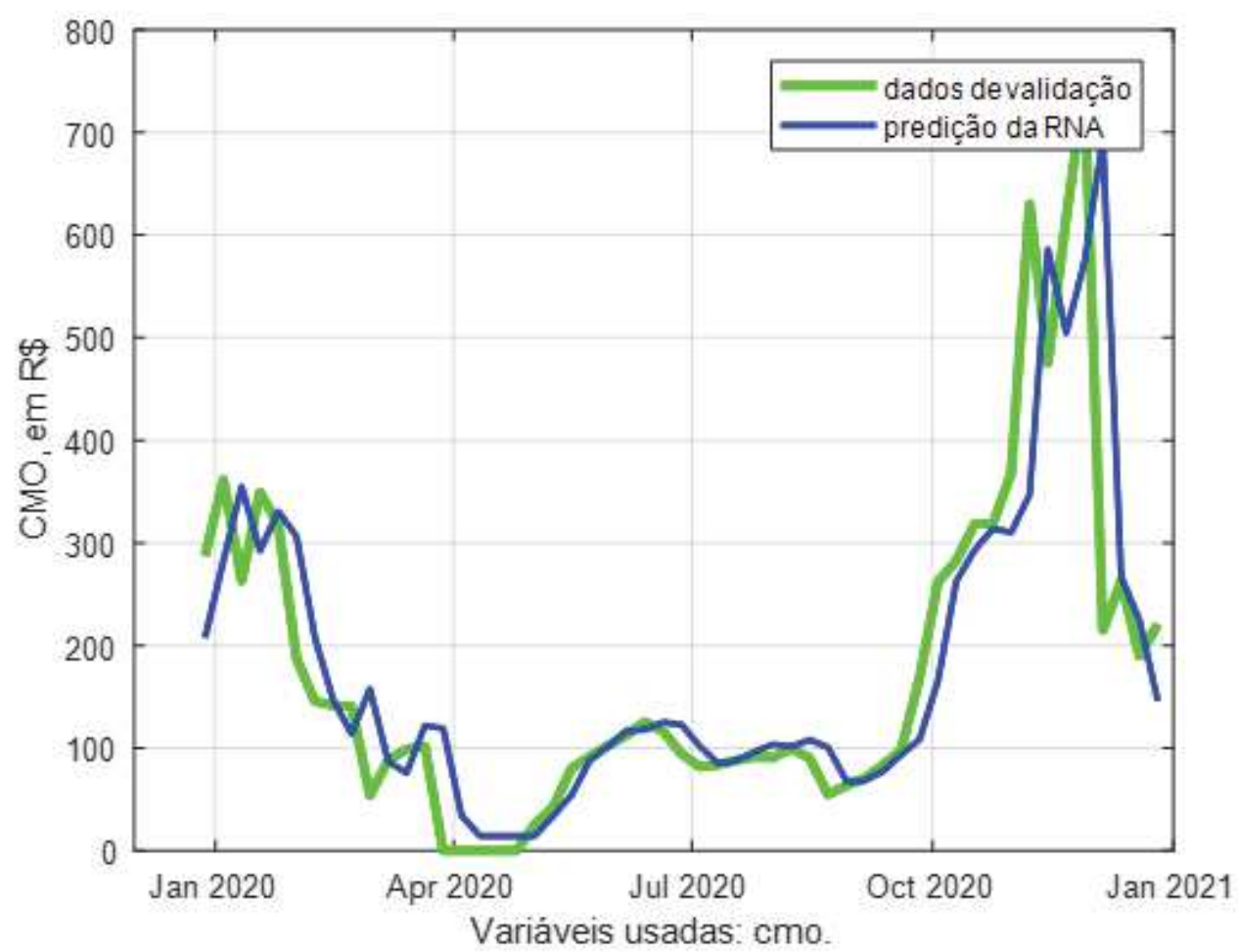

Figura 4.2 - Predição para $N_{1}=N_{2}=20$ e $n_{p}=n_{q}=20$.

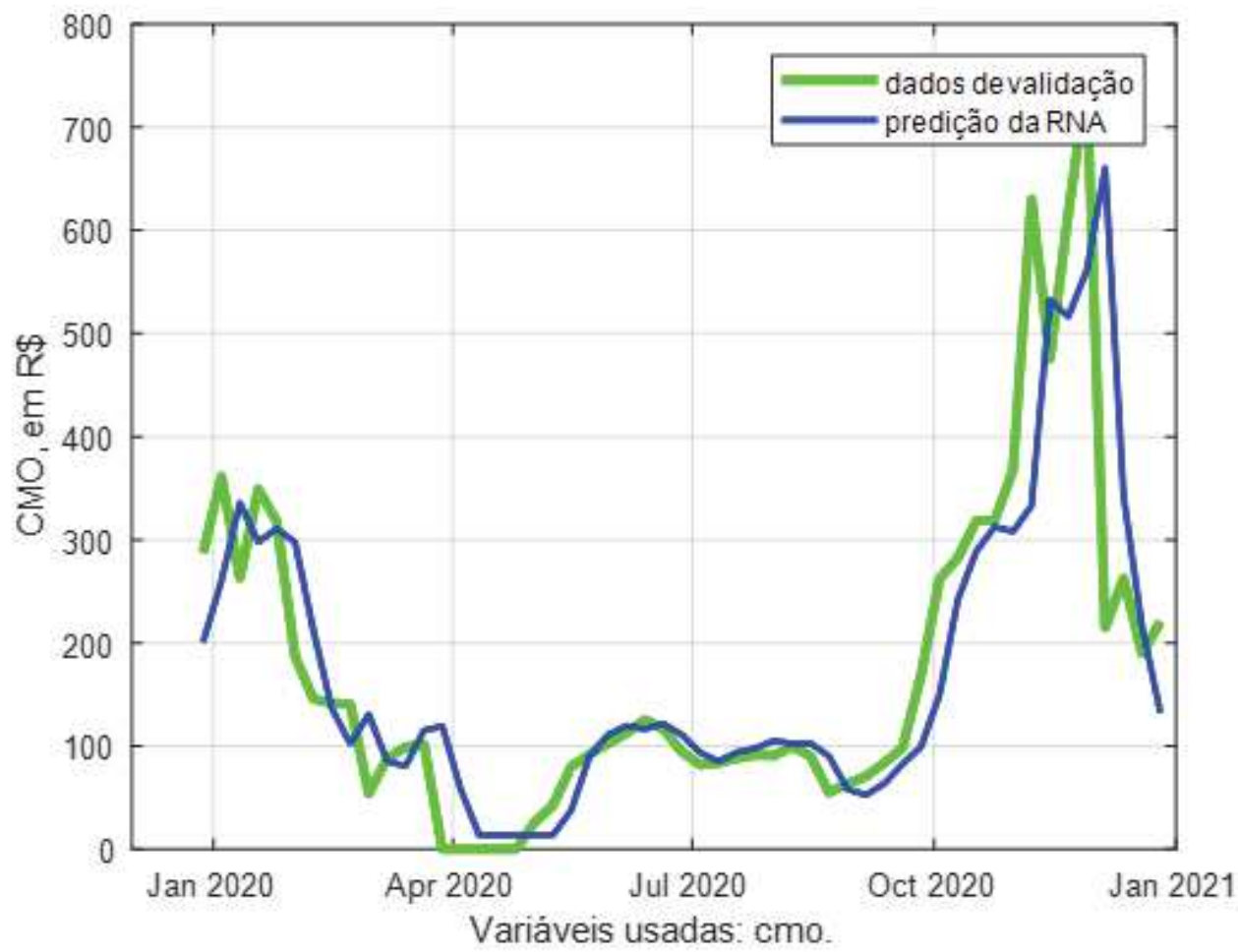


Figura 4.3 - Predição para $N_{1}=10 N_{2}=20 N_{3}=15$ e $n_{p}=n_{q}=10$.

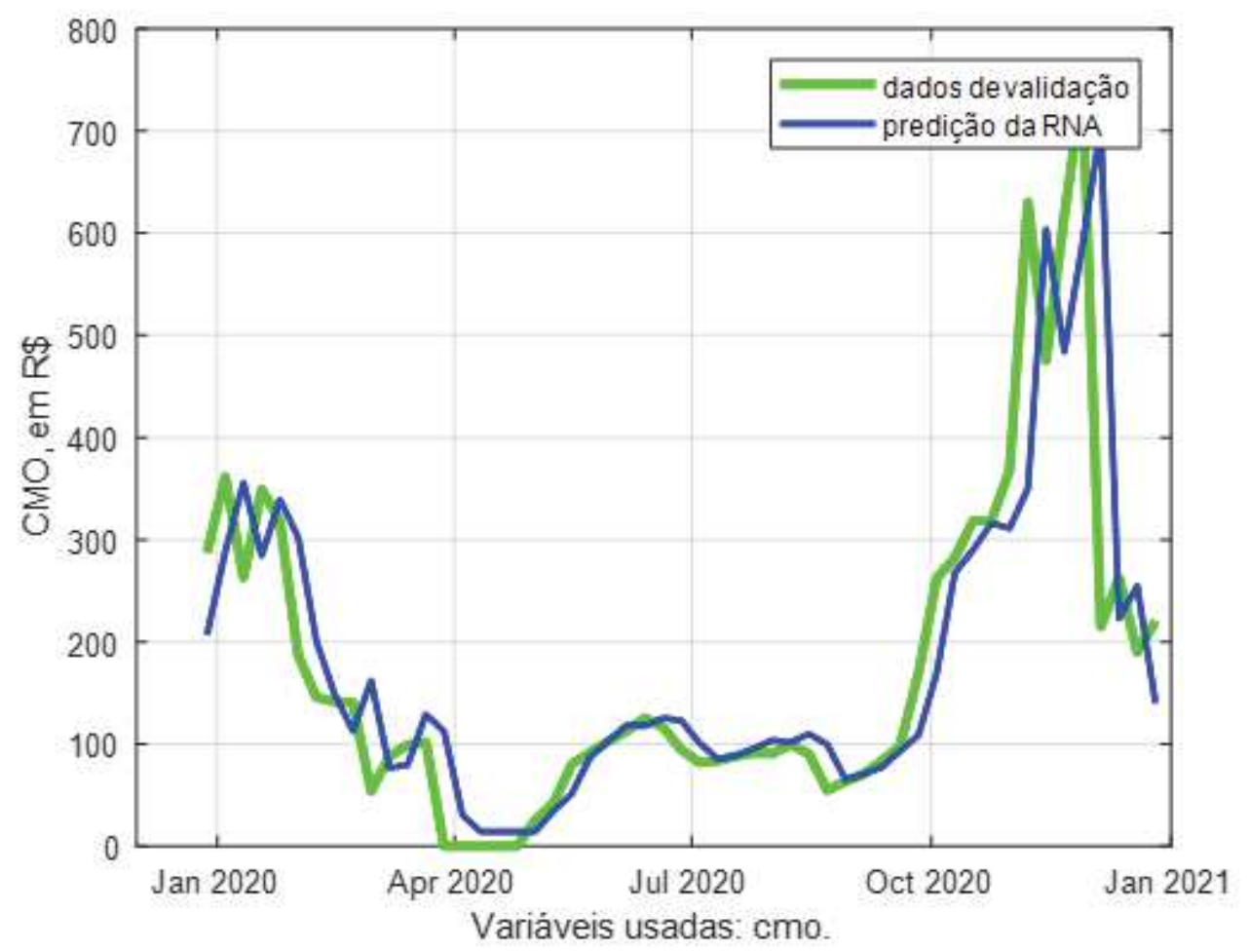

Figura 4.4 - Predição para $N_{1}=10 N_{2}=20 \quad N_{3}=15$ e $n_{p}=n_{q}=20$.

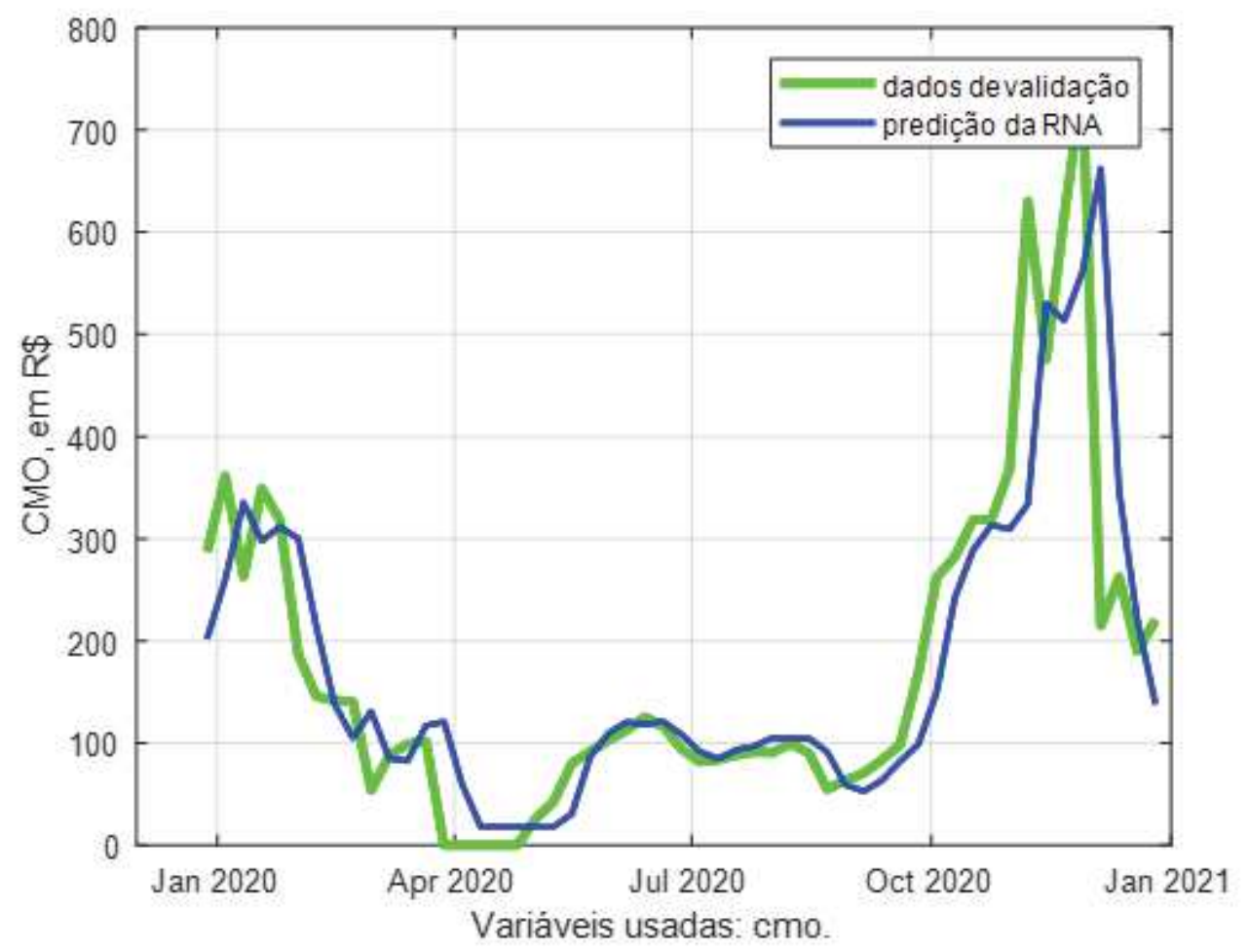


Figura 4.5 - Treinamento e Predição para $N_{1}=N_{2}=N_{3}=50$ e $n_{p}=n_{q}=30$.

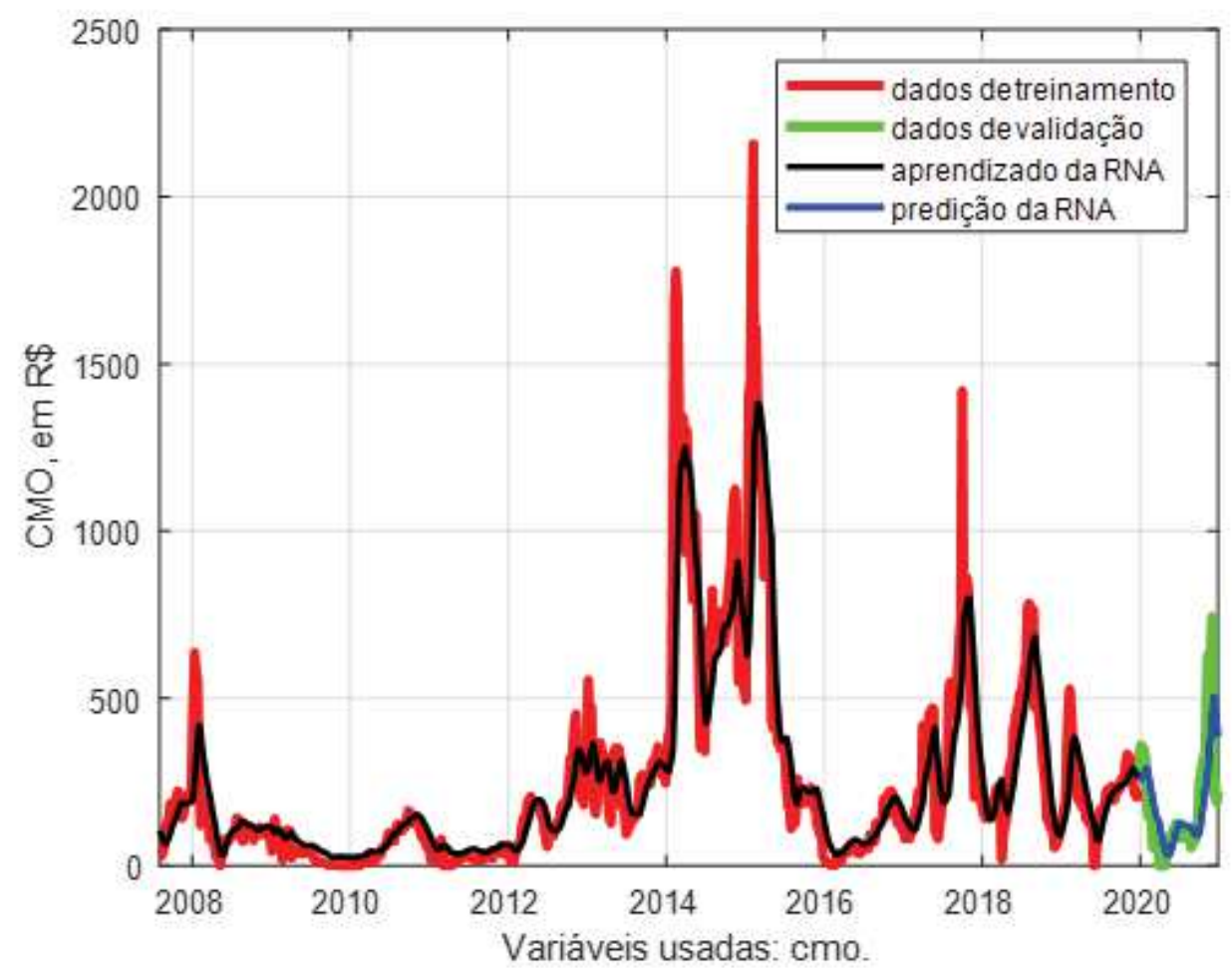

Figura 4.6 - Predição para $N_{1}=N_{2}=N_{3}=50$ e $n_{p}=n_{q}=30$.

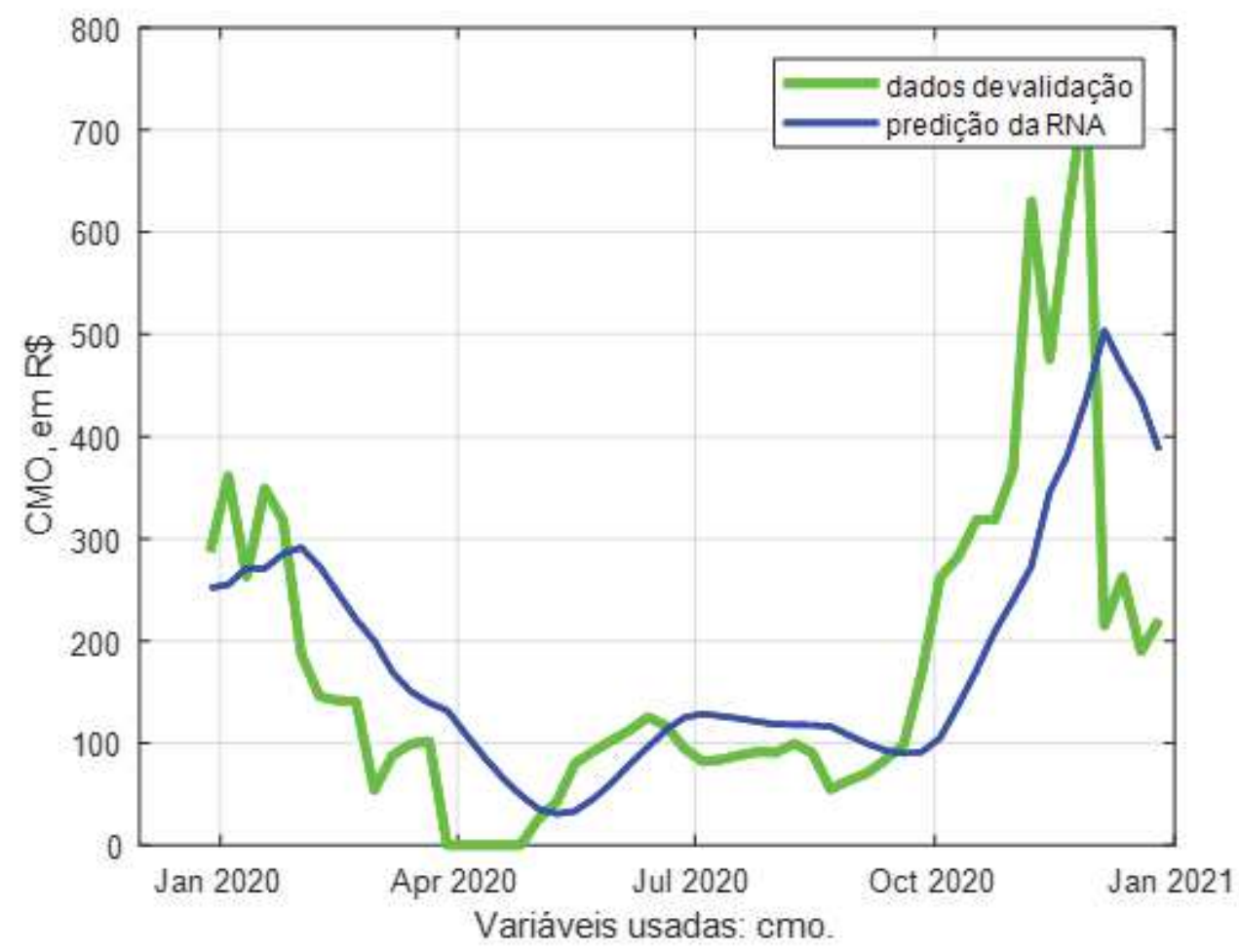


Na topologia com menor quantidade de camadas $\left(N_{1}=10\right)$ os indicadores retornaram os piores resultados, denotando a falta de capacidade de generalização. Contudo, mesmo as piores topologias, apresentam resultados consideráveis, com erros de aproximadamente 2,21 R \$/MWh demonstrando uma boa capacidade de generalização da rede e conseguindo capturar boas tendências dos preços, auxiliando tomadas de decisões no curtíssimo prazo.

\subsubsection{Predição de vários passos no futuro}

Esta seção apresenta os resultados considerando a predição de vários passos no futuro a cada rodada da rede, no caso, 1 ano completo. Nesta abordagem não estão disponíveis para a rede informações do conhecimento das semanas imediatamente anteriores na etapa de predição, sendo realimentada a rede pela sua própria predição futura.

De maneira a expor a diferença entre ambas as metodologias, tem-se a seguinte situação: a predição do dado futuro do tempo $t+1$ resulta na saída $y_{t+1}$ cujo resultado verdadeiro é $d_{t+1}$. Quão menor é o erro entre $y_{t+1}$ e $d_{t+1}$, melhor a generalização da rede. Para a topologia da seção anterior, que prediz apenas um passo no futuro, a predição do resultado do próximo tempo, $t+2$, utilizaria como dado realimentado o dado verdadeiro $d_{t+1}$, uma vez que este está disponível. Já a topologia desta seção realimentará a própria saída da rede, $y_{t+1}$, considerando que os dados verdadeiros não estão disponíveis.

Os testes foram feitos para as mesmas topologias apresentadas na seção anterior. A Tabela 4.2 apresenta os resultados quantitativos para a predição de até um ano no futuro (53 semanas) e as Figuras 4.7 e 4.8 apresentam os resultados quantitativos da melhor e pior topologia, respectivamente.

Tabela 4.2 - Resultados por topologia - vários passos no futuro ( $\mathrm{N}=53$ passos)

\begin{tabular}{|c|c|c|c|c|c|c|c|c|c|}
\hline \multicolumn{4}{|c|}{ Configurações da rede } & \multicolumn{3}{|c|}{ Treinamento } & \multicolumn{3}{|c|}{ Validação } \\
\hline$N_{1}$ & $\mathrm{~N}_{2}$ & $N_{3}$ & $\begin{array}{c}n_{p} \mathbf{e} \\
n_{q}\end{array}$ & $\begin{array}{c}\text { Erro } \\
\text { Quadrático } \\
\text { Médio }(\mathbf{R} \$)^{2}\end{array}$ & $\begin{array}{l}\text { Erro } \\
\text { Médio } \\
(\mathbf{R} \$)\end{array}$ & $\begin{array}{l}\text { Desvio } \\
\text { Padrão }\end{array}$ & $\begin{array}{c}\text { Erro } \\
\text { Quadrático } \\
\text { Médio }(\mathbf{R} \$)^{2}\end{array}$ & $\begin{array}{l}\text { Erro } \\
\text { Médio } \\
(\mathbf{R} \$)\end{array}$ & $\begin{array}{l}\text { Desvio } \\
\text { Padrão }\end{array}$ \\
\hline \multirow{4}{*}{10} & \multirow{4}{*}{ - } & \multirow{4}{*}{ - } & 2 & 40,1190 & 6,3340 & 16,9981 & 12,2712 & 3,5030 & 12,8151 \\
\hline & & & 10 & 32,0223 & 5,6588 & 16,1098 & 12,2886 & 3,5055 & 12,7913 \\
\hline & & & 20 & 33,3683 & 5,7765 & 16,1887 & 12,4814 & 3,5329 & 12,8728 \\
\hline & & & 30 & 6,9219 & 2,6310 & 11,0538 & 12,7619 & 3,5724 & 12,8793 \\
\hline \multirow{4}{*}{20} & \multirow{4}{*}{20} & \multirow{4}{*}{-} & 2 & 4,5580 & 2,1350 & 9,9590 & 12,3320 & 3,5117 & 12,8277 \\
\hline & & & 10 & 5,2482 & 2,2909 & 10,3092 & 12,5313 & 3,5400 & 12,8856 \\
\hline & & & 20 & 34,8049 & 5,8996 & 16,4250 & 12,4607 & 3,5300 & 12,8457 \\
\hline & & & 30 & 6,0815 & 2,4661 & 10,6949 & 12,6414 & 3,5555 & 12,9138 \\
\hline \multirow{4}{*}{10} & \multirow{4}{*}{20} & \multirow{4}{*}{15} & 2 & 44,2286 & 6,6505 & 17,4201 & 12,2794 & 3,5042 & 12,8164 \\
\hline & & & 10 & 44,9028 & 6,7010 & 17,2718 & 12,4960 & 3,5350 & 12,8050 \\
\hline & & & 20 & 42,1993 & 6,4961 & 17,1117 & 12,3015 & 3,5073 & 12,8202 \\
\hline & & & 30 & 40,1005 & 6,3325 & 17,0009 & 12,4708 & 3,5314 & 12,8505 \\
\hline \multirow{4}{*}{50} & \multirow{4}{*}{50} & \multirow{4}{*}{50} & 2 & 4,6222 & 2,1499 & 9,9921 & 12,3299 & 3,5114 & 12,8336 \\
\hline & & & 10 & 4,9279 & 2,2199 & 10,1529 & 12,5194 & 3,5383 & 12,8690 \\
\hline & & & 20 & 34,9152 & $\begin{array}{l}5,9089 \\
\end{array}$ & 16,3336 & 12,3904 & 3,5200 & 12,8430 \\
\hline & & & 30 & 35,5607 & 5,9633 & 16,4486 & 15,5224 & 3,5387 & 12,8833 \\
\hline
\end{tabular}


Figura 4.7 - Predição para $N_{1}=N_{2}=20$ e $n_{p}=n_{q}=2$.

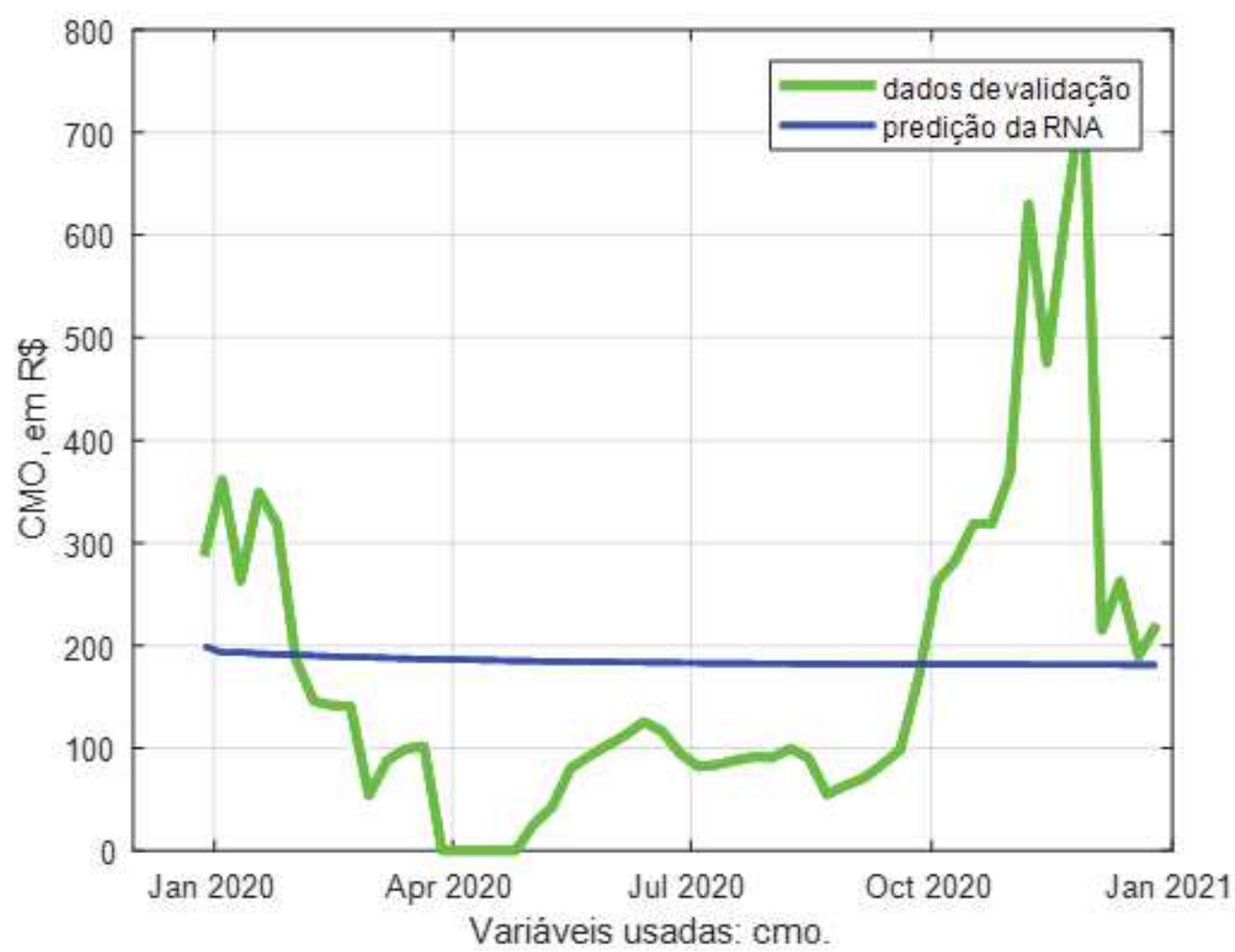

Figura 4.8 - Predição para $N_{1}=10, N_{2}=20, N_{3}=15$ e $n_{p}=n_{q}=2$.

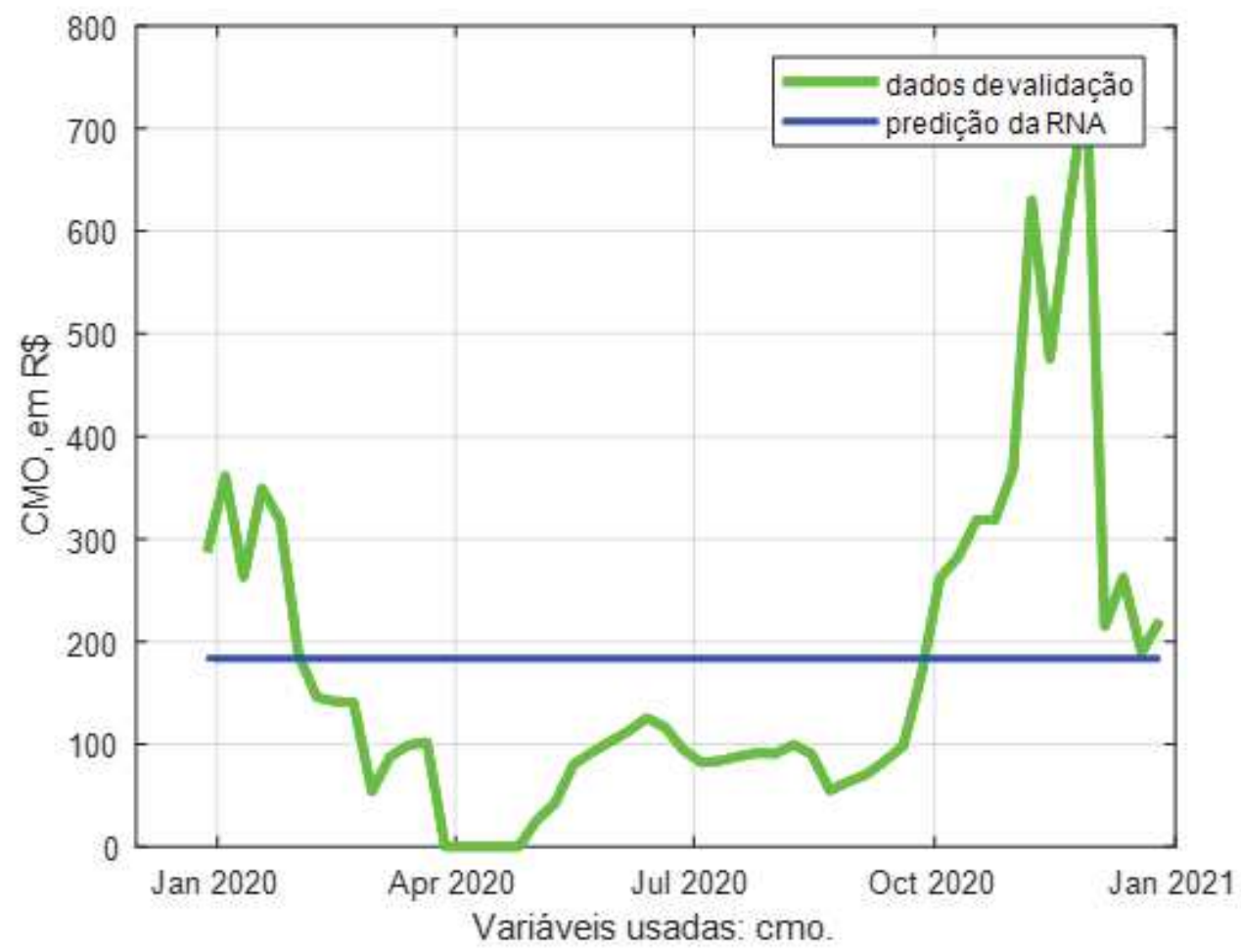


Como pode-se observar, as Figuras 4.7 e 4.8 convergiram para a média dos dados. Esta é uma particularidade do método de treinamento, o $A D A M$, por ser um treinamento estocástico baseado no primeiro e segundo momentos estatísticos, é esperado que minimize ambos na fase de atualização dos pesos sinápticos. O resultado produzido convergiu para próximo da média anual de preços do $\mathrm{CMO}$, o que não é um resultado satisfatório em termos de captura de tendências da variável ao longo do ano.

Estratégia similar foi executada em (NASCIMENTO et al., 2019), porém, com outro método de treinamento, o Resilient Backpropagation, e para a variável PLD, que, conforme visto ao longo deste trabalho, é uma versão saturada do CMO. Nesta oportunidade, verificou-se um comportamento diferente imposto pelo método de treinamento, a predição não convergiu para a média e sim, para um comportamento de alta volatilidade. Porém, o resultado de predição para vários passos no futuro mostrou-se também não satisfatório.

A conclusão que se levanta para ambos os resultados é que a própria variável, CMO (e, consequentemente, PLD), não possuem informações suficientes dentro de si próprias, para realizar uma predição futura para vários passos. Estas variáveis não possuem estruturas de repetição periódicas ao longo do tempo, e são contaminadas por ruídos aleatórios. Estes fatores, em conjunto, tornam esta variável imprópria para predição de longo prazo se utilizada sem nenhum outro tipo de informação adicional.

Esta conclusão também é suportada pela Figura 4.9, que mostra a correlação cruzada do CMO consigo mesmo, para janelas temporais diferentemente deslocadas no tempo. Nota-se que o mesmo possui alta correlação na diagonal e seu entorno, a situação em que as janelas estão temporalmente pouco distantes, sendo uma possível explicação para o bom desempenho da predição de uma semana a frente. No entanto, se o distanciamento temporal das janelas é grande, a correlação é baixa, o que lembra o comportamento de uma variável aleatória, dada na Figura 4.10. Esta pode ser uma das razões da predição de vários passos não funcionar bem para uma rede cujas entradas sejam alimentadas apenas pelo CMO, uma vez que não exista uma correlação temporal de longo alcance para o CMO. Seriam necessárias, portanto, outras fontes de informação nas entradas da Rede Neural para que a mesma pudesse aprender padrões úteis na predição de longo prazo do CMO.

No entanto, o CMO/PLD é composto por outras variáveis, conforme exposto ao longo dos capítulos, variáveis estas disponíveis no ONS (ONS, 2020). O mecanismo de confecção do CMO/PLD leva em consideração diversas informações disponíveis no histórico do ONS. Portanto, para que informações adicionais úteis sejam inseridas na Rede Neural, de forma que esta possa capturar as tendências e auxiliar especialistas na tomada de decisões contratuais, diversas variáveis da ONS foram consideradas estatisticamente. Correlações entre estas variáveis e o CMO foram calculadas para diversas janelas temporais e testadas como entradas da Rede Neural, com o objetivo de fornecer informações importantes para o aprendizado de padrões. 
Figura 4.9 - Correlação cruzada do CMO para janelas de dados da série temporal, evidenciando a correlação entre dados da mesma série temporal em tempos diferentes.

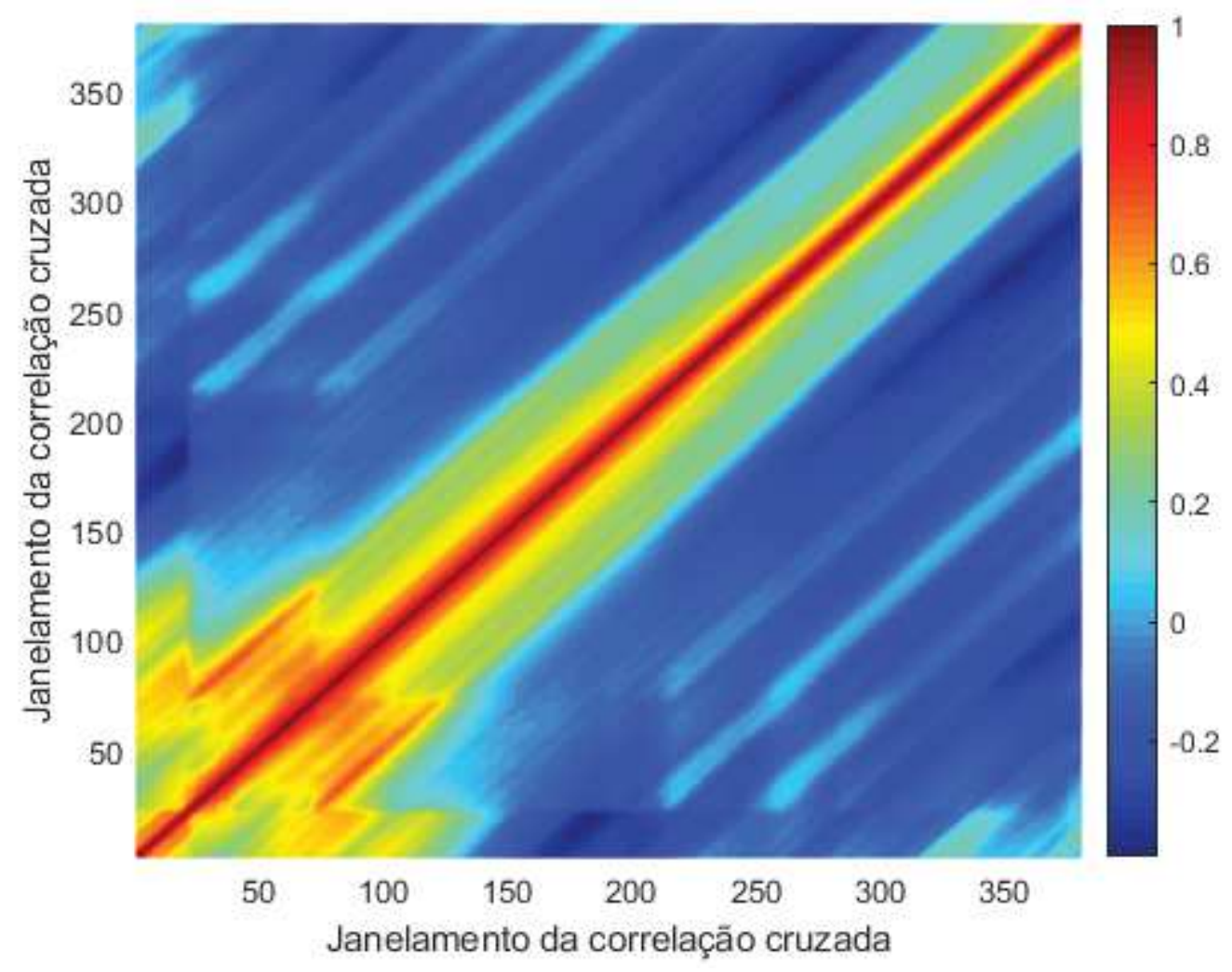

Figura 4.10 - Correlação cruzada: esquerda) CMO e direita) ruído Gaussiano, evidenciando a baixa correlação do CMO para janelas em instantes de tempos distantes, de maneira similar a variável aleatória, que não uma possui alta intensidade de estruturas repetidas ou periódicas no longo prazo.
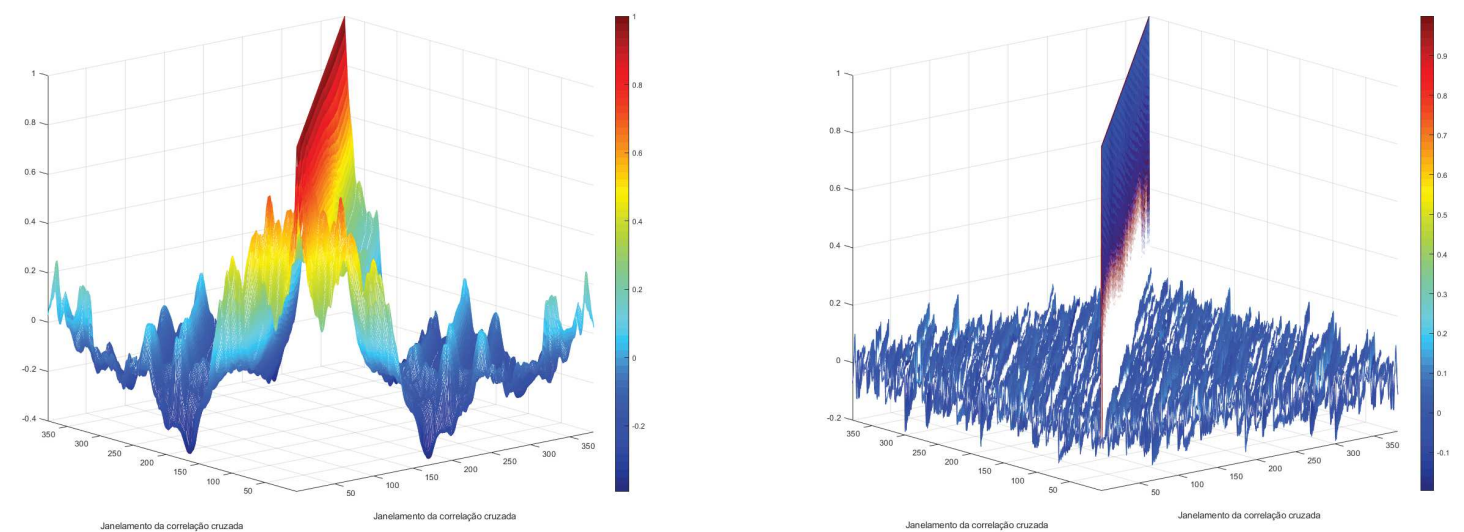


\subsection{Variáveis ONS como variáveis de entrada}

Para seleção das variáveis explanatórias a comporem a base de dados de entrada, foi realizada uma análise de correlação que indica a similaridade de cada variável com o CMO. Esta análise foi feita por meio de janelamentos de 2 à 730, que é o número total de dados. Para cada janelamento, calculou-se a correlação entre cada variável e o CMO. A correlação em janelas foi realizada pois, em uma rede com entradas atrasadas no tempo TDNN ( Time Delay Neural Network), a predição de valores posteriores a partir do instante $t$, associadas ao comportamento do processo, é computada em função do conhecimento de seus valores imediatamente anteriores, isto é:

$$
x(t)=f\left(x(t-1), x(t-2), \ldots, x\left(t-n_{p}\right)\right)
$$

em que $n_{p}$ é a quantidade de amostras passadas que serão necessárias para fazer a estimativa de do valor $x(t)$.

Estes atrasos de tempo garantem que as amostras anteriores que refletem o comportamento temporal do processo sejam sempre inseridas dentro da rede. Desta forma, a correlação janelada permite a escolha do melhor número de atrasos de tempo nas entradas, ou seja, aquele que indicar a melhor correlação entre as variáveis de maneira a maximizar as chances da rede ter uma boa predição.

A Figura 4.11 apresenta a correlação absoluta das variáveis com o CMO em função do tamanho das janelas. O indicador de correlação varia de -1 a 1 , onde 0 representa nenhuma correlação entre as variáveis. Na correlação positiva, à medida que uma variável cresce a outra também cresce e na negativa, à medida que uma cresce a outra decresce.

Nota-se, por inspeção visual, que a melhor variável analisada em termos de correlação é a Energia Armazenada (EA), que em todas as situações de janelamento mantém uma correlação superior a 0,5. É possível observar ainda, que a partir de janelas de tamanho 400, há uma estabilização da correlação. Contudo, em função do número limitado de amostras, é necessário escolher a menor janela possível que mantenha um nível aceitável de correlação, de forma que haja dados suficientes de entrada para que a rede consiga generalizá-los. Para escolher o melhor número de entradas atrasadas no tempo, foi feita uma análise das correlações para janelamentos de até 30 dados, conforme evidenciado na Figura 4.12.

Analisando a Figura 4.12 para as variáveis nos 30 primeiros intervalos, nota-se que existe uma estabilização da correlação para as 30 primeiras janelas. Portanto, a RNA desta dissertação foi implementada com valores de atrasos TDNN das entradas de até 30, pois existe uma queda na correlação dos dados após 30 atrasos (vide Figura 4.11) e, além disso, existe um número limitado de dados restritivo ao crescimento do número de entradas da rede. Testes posteriores serão feitos de modo a selecionar o melhor número possível de atrasos TDNN dentro deste intervalo [1,30]. Além disso, a variável ENA e IE 
Figura 4.11 - Correlação das variáveis com o CMO para janelamentos de até 730 dados.

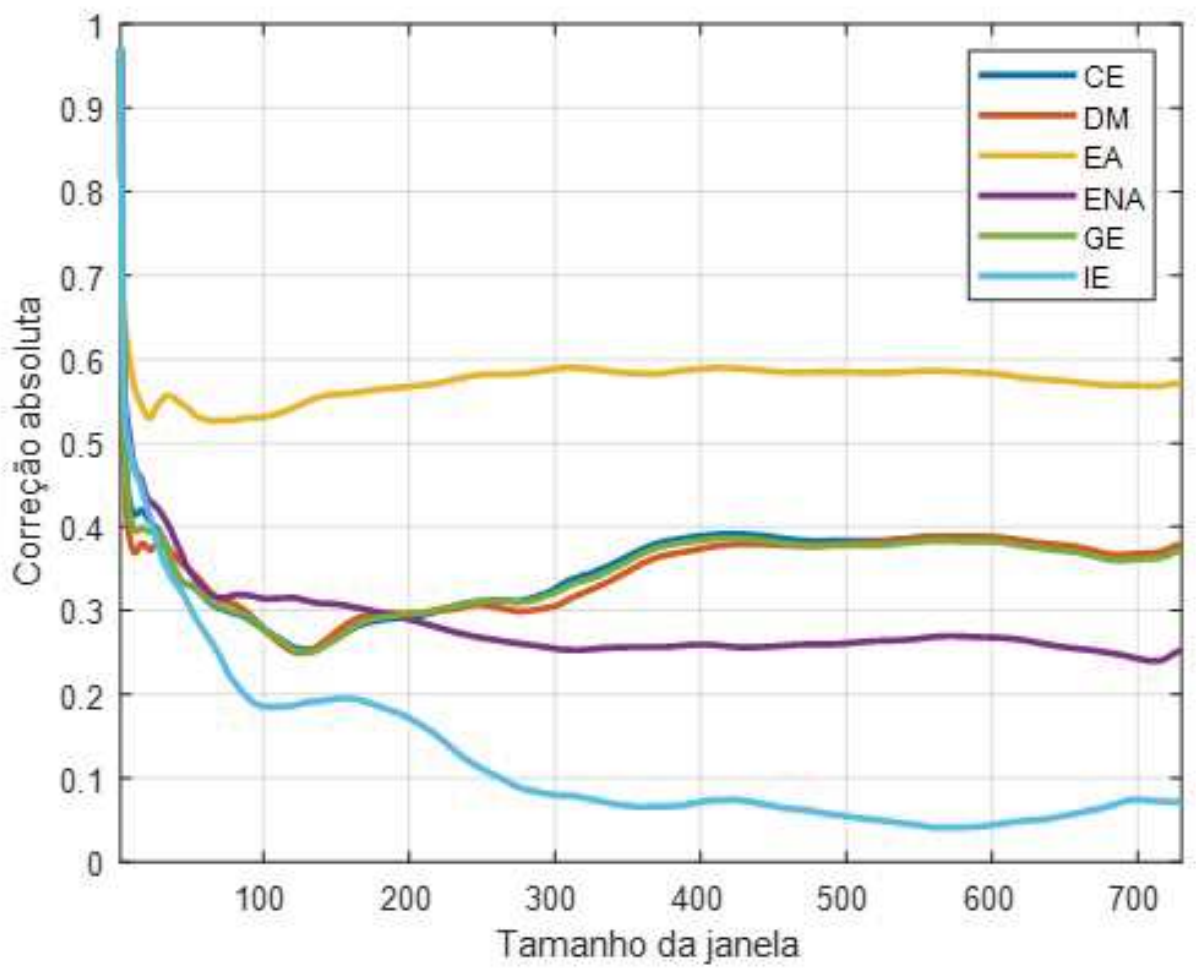

Figura 4.12 - Correlação das variáveis com o CMO para janelamentos de até 30 dados.

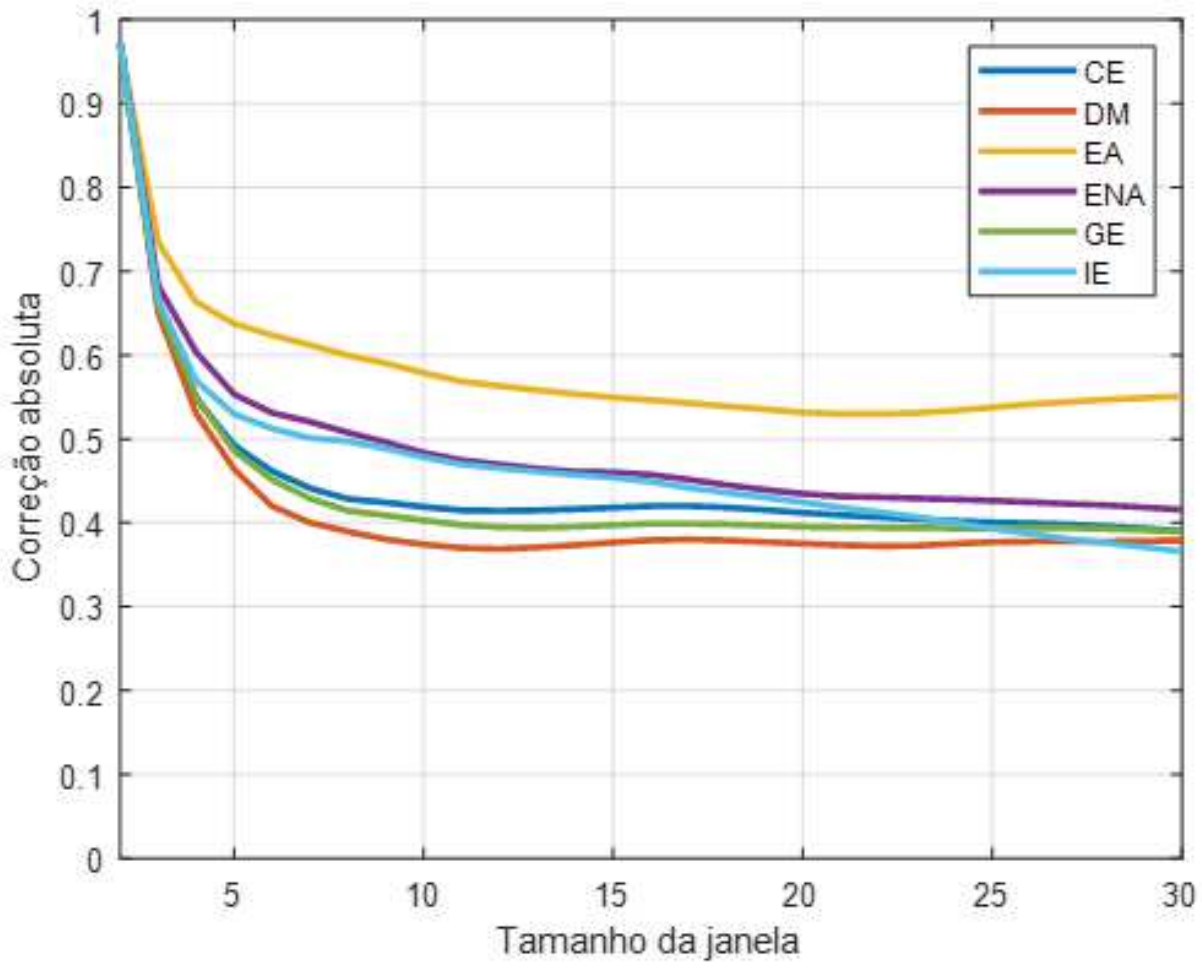


também poderão ser consideradas como novas entradas da Rede Neural caso se provem úteis na predição, pois, para os primeiros atrasos elas possuem um comportamento melhor que as outras variáveis, e apenas no longo prazo (janelas grandes) é que perdem qualidade de correlação.

Nesta abordagem serão utilizadas séries de dados de diversas variáveis importantes relacionadas à composição do CMO e, consequentemente, do PLD. A predição será feita para vários passos no futuro a cada rodada da rede. Conforme citado na seção 4.1.2, a predição do dado futuro do tempo $t+1$ resulta na saída $y_{t+1}$ cujo resultado verdadeiro é $d_{t+1}$. Como a presente dissertação pretende analisar de forma investigativa da variável CMO, a topologia desta seção realimentará a própria saída da rede, $y_{t+1}$, considerando que os dados verdadeiros $d$ futuros não estão disponíveis. Contudo, adota-se como conhecidas as demais variáveis nos tempos futuros, em razão de não precisar predizê-las também. Desta forma, a predição do resultado do próximo tempo, $t+2$ para as demais variáveis, utiliza como dado realimentado o dado verdadeiro $t+1$, uma vez que este está disponível nesta abordagem.

Inicialmente, foram simuladas RNAs tendo como entradas as séries TDNN das variáveis $\mathrm{CE}, \mathrm{DM}, \mathrm{EA}, \mathrm{GE}$, além do próprio CMO e PLD. Ou seja, optou-se por excluir as variáveis que apresentaram pior correlação com o CMO, a saber, ENA e IE. As topologias testadas foram as mesmas analisadas na abordagem anterior, da Seção 4.1, utilizando apenas o CMO como entrada da rede. As mesmas redes foram utilizadas em função de seus parâmetros fixados na seção inicial deste capítulo. Os resultados estão dispostos na Tabela 4.3.

Tabela 4.3 - Resultados por topologia (CE, DM, EA, GE, CMO e PLD) - vários passos no futuro (1 ano)

\begin{tabular}{|c|c|c|c|c|c|c|c|c|c|}
\hline \multicolumn{4}{|c|}{ Configuração da rede } & \multicolumn{3}{|c|}{ Treinamento } & \multicolumn{3}{|c|}{ Validação } \\
\hline$N_{1}$ & $N_{2}$ & $N_{3}$ & $\begin{array}{c}n_{p} \mathbf{e} \\
n_{q}\end{array}$ & $\begin{array}{c}\text { Erro } \\
\text { Quadrático } \\
\text { Médio }(\mathbf{R} \$)^{2}\end{array}$ & $\begin{array}{c}\text { Erro } \\
\text { Médio } \\
(\mathbf{R} \$)\end{array}$ & $\begin{array}{l}\text { Desvio } \\
\text { Padrão }\end{array}$ & $\begin{array}{c}\text { Erro } \\
\text { Quadrático } \\
\text { Médio }(\mathbf{R} \$)^{2}\end{array}$ & $\begin{array}{l}\text { Erro } \\
\text { Médio } \\
(\mathbf{R} \$)\end{array}$ & $\begin{array}{l}\text { Desvio } \\
\text { Padrão }\end{array}$ \\
\hline \multirow{4}{*}{10} & \multirow{4}{*}{-} & \multirow{4}{*}{-} & 2 & 6,9364 & 2,6337 & 11,0624 & 7,8569 & 2,8030 & 11,0703 \\
\hline & & & 10 & 7,5244 & 2,7431 & 11,2421 & 6,7167 & 2,5917 & 10,9589 \\
\hline & & & 20 & 6,4877 & 2,5471 & 10,7635 & 5,3162 & 2,3057 & 10,3329 \\
\hline & & & 30 & 8,0586 & 2,8388 & 11,2613 & 7,0889 & 2,6625 & 11,1130 \\
\hline \multirow{4}{*}{20} & \multirow{4}{*}{20} & \multirow{4}{*}{ - } & 2 & 4,7808 & 2,1865 & 10,0259 & 7,2070 & 2,6846 & 11,1655 \\
\hline & & & 10 & 4,2412 & 2,0594 & 9,7147 & 6,4533 & 2,5403 & 10,9158 \\
\hline & & & 20 & 5,5246 & 2,3504 & 10,4106 & 5,1836 & 2,2767 & 10,3339 \\
\hline & & & 30 & 4,8630 & 2,2052 & 9,8928 & 7,2484 & 2,6923 & 11,1810 \\
\hline \multirow{4}{*}{10} & \multirow{4}{*}{20} & \multirow{4}{*}{15} & 2 & 5,2949 & 2,3011 & 10,2931 & 6,9168 & 2,6300 & 11,1021 \\
\hline & & & 10 & 6,5496 & 2,5592 & 10,8294 & 6,4946 & 2,5484 & 10,9327 \\
\hline & & & 20 & 6,1860 & 2,4872 & 10,6643 & 5,5283 & 2,3512 & 10,4684 \\
\hline & & & 30 & 6,6911 & 2,5867 & 10,7931 & 6,7386 & 2,5959 & 10,9707 \\
\hline \multirow{4}{*}{50} & \multirow{4}{*}{50} & \multirow{4}{*}{50} & 2 & 6,2682 & 2,5036 & 10,5066 & 5,7029 & 2,3881 & 10,4278 \\
\hline & & & 10 & 6,2168 & 2,4934 & 10,7003 & 5,8604 & 2,4208 & 10,6538 \\
\hline & & & 20 & 7,1964 & 2,6826 & 11,0854 & 4,9575 & 2,2265 & 10,1728 \\
\hline & & & 30 & 8,6566 & 3,1075 & 11,9237 & 6,9481 & 2,6359 & 11,0824 \\
\hline
\end{tabular}


A topologia que apresentou melhor resultado quantitativo de predição é a composta por 3 camadas escondidas com 50 neurônios cada. Embora não seja a configuração com os menores erros de treinamento, nota-se nas Figuras 4.13 e 4.14, as quais apresentam graficamente o desempenho da rede, que a mesma foi capaz de capturar a tendência geral da variação anual do CMO, mostrando os picos e vales nos preços, evidenciando quais são as épocas do ano melhores para eventuais contratos de compra e venda de energia.

Figura 4.13 - Treinamento e Predição para $N_{1}=N_{2}=N_{3}=50$ e $n_{p}=n_{q}=20$.

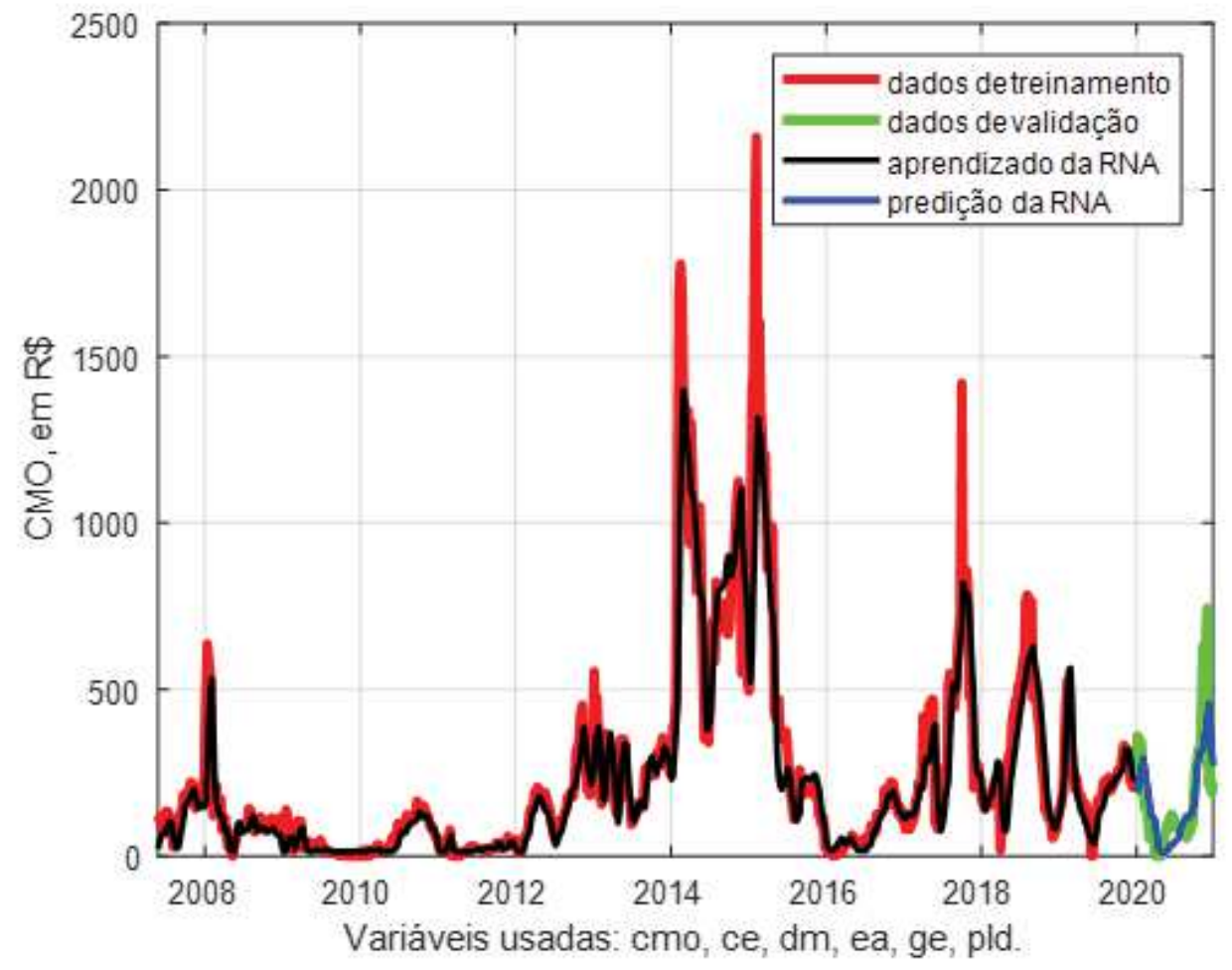

Na sequência de melhores resultados, tem-se a rede com 2 camadas escondidas $\left(N_{1}=N_{2}=20\right)$ e atrasos de entrada $n_{p}$ e realimentação $n_{q}$ iguais a 20 . Esta rede produz um resultado qualitativo muito semelhante à topologia com melhor desempenho, conforme evidenciado na Figura 4.15. Desta maneira, é possível concluir que duas camadas escondidas possuem a capacidade de capturar as tendências da variável com uma menor complexidade computacional sem perda significativa na qualidade dos dados preditos.

É possível observar nos resultados apresentados na Tabela 4.3 que os menores erros para cada topologia, considerando o número de camadas e número de neurônios por camada, são obtidos quando os atrasos $n_{p}$ e $n_{q}$ equivalem a 20. Com menos neurônios a captura de padrões não é tão efetiva, e com mais neurônios a rede torna-se redundante, provocando uma má generalização (excessiva) dos dados. Conforme apresentado na Figura 4.12, manter o número de atrasos em até 30 dados produz resultados de correlação próximos para todas as variáveis. Sendo assim, a RNA foi simulada com todas as variáveis como entrada da rede, com os resultados produzidos dispostos na Tabela 4.4. 
Figura 4.14 - Predição para $N_{1}=N_{2}=N_{3}=50$ e $n_{p}=n_{q}=20$.

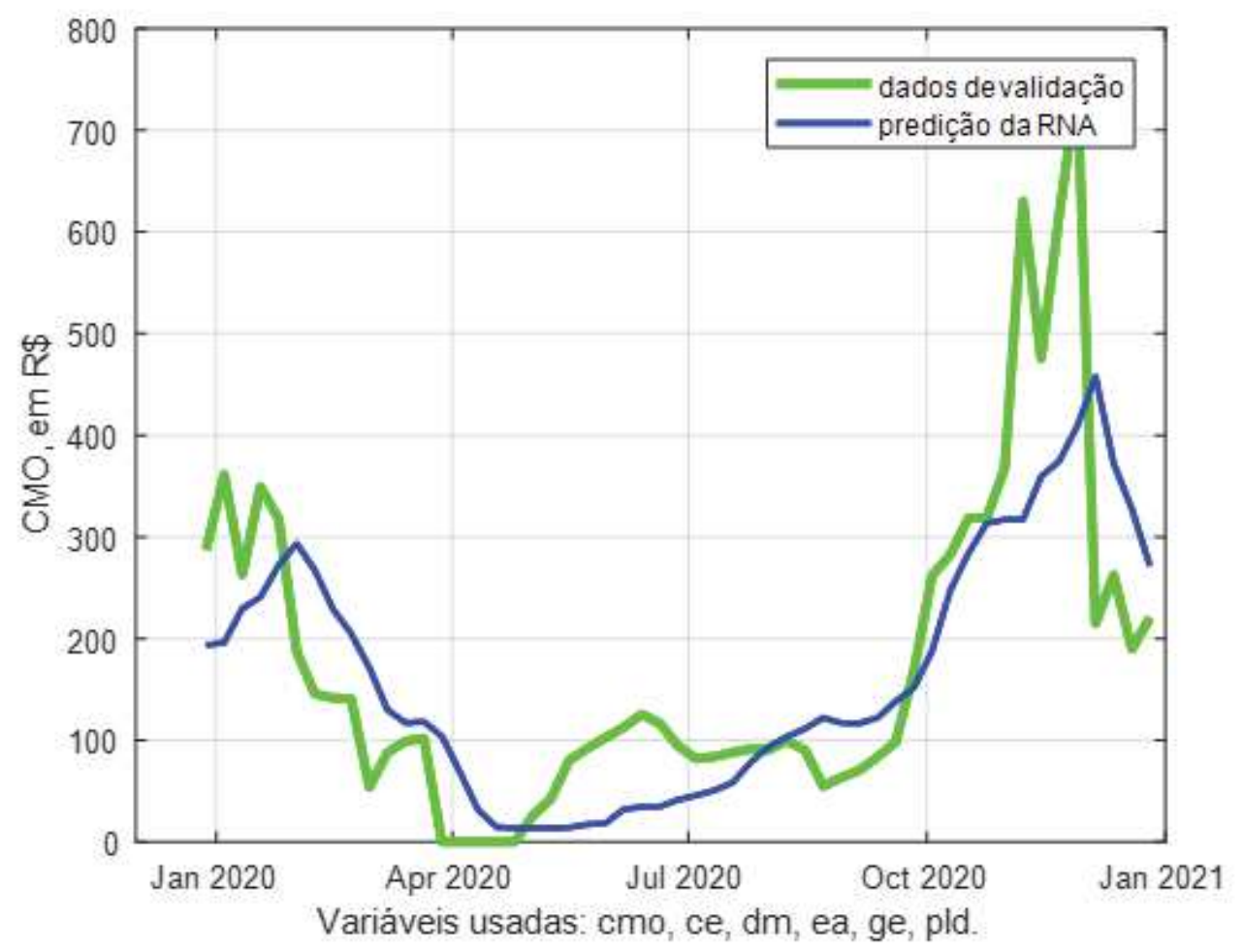

Figura 4.15 - Predição para $N_{1}=N_{2}=20$ e $n_{p}=n_{q}=20$.

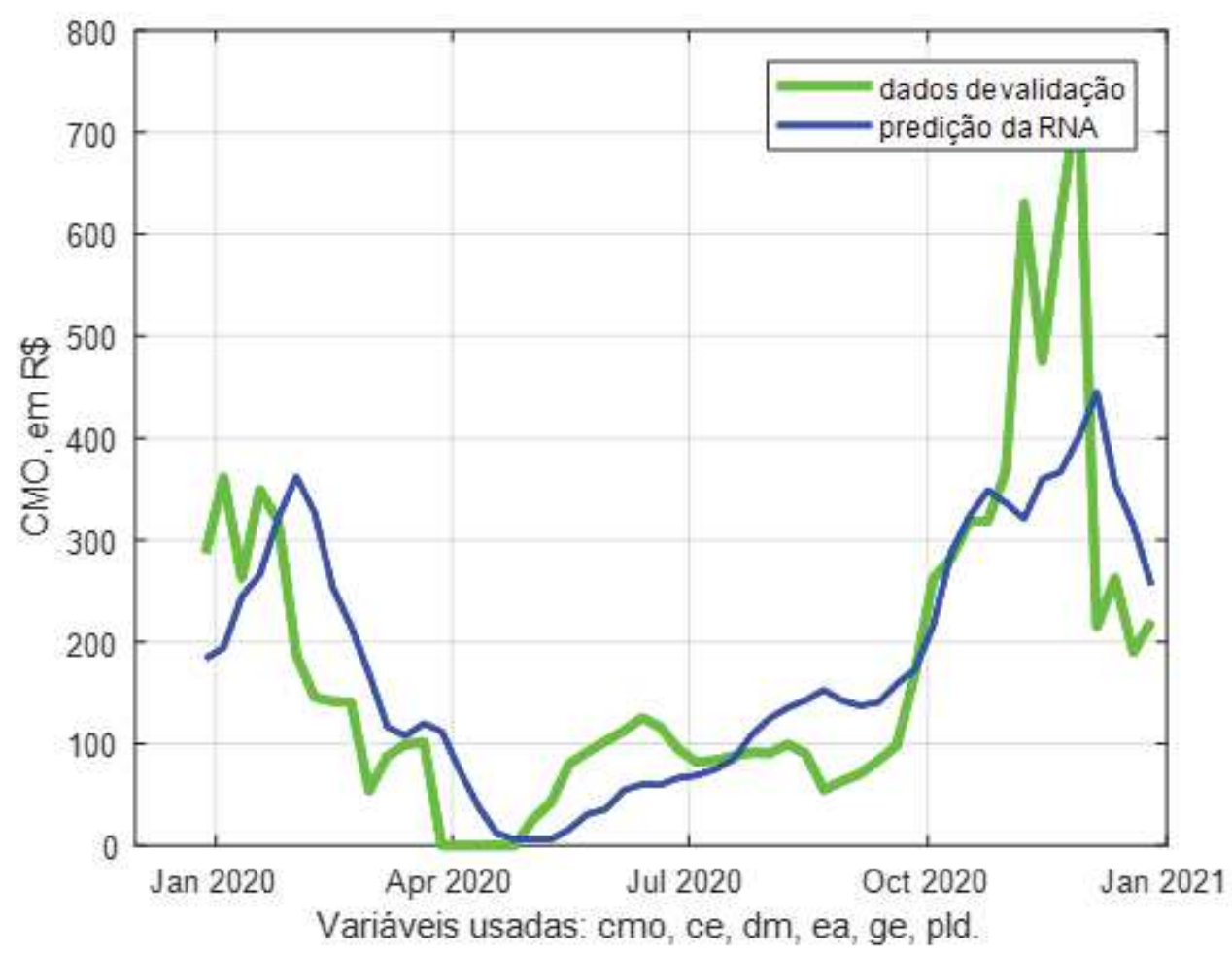


Tabela 4.4 - Resultados por topologia (CE, DM, EA, GE, IE, ENA, CMO e PLD) - vários passos no futuro (1 ano)

\begin{tabular}{|c|c|c|c|c|c|c|c|c|c|}
\hline \multicolumn{4}{|c|}{ Configurações da rede } & \multicolumn{3}{|c|}{ Treinamento } & \multicolumn{3}{|c|}{ Validação } \\
\hline$N_{1}$ & $N_{2}$ & $N_{3}$ & $\begin{array}{c}n_{p} \mathbf{e} \\
n_{q}\end{array}$ & $\begin{array}{c}\text { Erro } \\
\text { Quadrático } \\
\text { Médio }(\mathbf{R} \$)^{2}\end{array}$ & $\begin{array}{l}\text { Erro } \\
\text { Médio } \\
(\mathbf{R} \$)\end{array}$ & $\begin{array}{l}\text { Desvio } \\
\text { Padrão }\end{array}$ & $\begin{array}{c}\text { Erro } \\
\text { Quadrático } \\
\text { Médio }(\mathbf{R} \$)^{2}\end{array}$ & $\begin{array}{l}\text { Erro } \\
\text { Médio } \\
(\mathbf{R} \$)\end{array}$ & $\begin{array}{l}\text { Desvio } \\
\text { Padrão }\end{array}$ \\
\hline \multirow{4}{*}{10} & \multirow{4}{*}{$\mathrm{x}$} & \multirow{4}{*}{$\mathrm{x}$} & 2 & 6,7917 & 2,6061 & 11,0053 & 8,4328 & 2,9039 & 10,5715 \\
\hline & & & 10 & 9,2775 & 3,0459 & 11,8477 & 5,1350 & 2,2661 & 10,2821 \\
\hline & & & 20 & 5,5850 & 2,3633 & 10,3906 & 6,9393 & 2,6343 & 11,0963 \\
\hline & & & 30 & 15,4887 & 3,9356 & 13,5273 & 10,9649 & 3,3113 & 12,4565 \\
\hline \multirow{4}{*}{20} & \multirow{4}{*}{20} & \multirow{4}{*}{$\mathrm{x}$} & 2 & 5,2171 & 2,2841 & 10,2585 & 6,1462 & 2,4791 & 10,2577 \\
\hline & & & 10 & 6,9043 & 2,6276 & 10,9604 & 5,0900 & 2,2561 & 10,2322 \\
\hline & & & 20 & 3,4488 & 1,8571 & 9,2672 & 6,4169 & 2,5322 & 10,8208 \\
\hline & & & 30 & 5,9358 & 2,4364 & 10,6243 & 10,6884 & 3,2693 & 12,2286 \\
\hline \multirow{4}{*}{10} & \multirow{4}{*}{20} & \multirow{4}{*}{15} & 2 & 4,5675 & $\begin{array}{l}2,1372 \\
\end{array}$ & 9,9294 & 5,8822 & 2,4253 & 10,6371 \\
\hline & & & 10 & 4,9867 & 2,2331 & 9,9990 & 5,3268 & 2,3080 & 10,3976 \\
\hline & & & 20 & 4,5105 & 2,1238 & 9,8674 & 6,9800 & 2,6420 & 11,0615 \\
\hline & & & 30 & 6,1091 & 2,4717 & 10,7200 & 10,1956 & 3,1931 & 12,1827 \\
\hline \multirow{4}{*}{50} & \multirow{4}{*}{50} & \multirow{4}{*}{50} & 2 & 4,4300 & 2,1047 & 9,7030 & 4,3991 & 2,0947 & 9,8723 \\
\hline & & & 10 & 6,2309 & $\begin{array}{l}2,4962 \\
\end{array}$ & 10,6137 & 4,8588 & 2,2043 & 10,1557 \\
\hline & & & 20 & 10,6026 & 3,2562 & 12,3035 & 7,3011 & 2,7021 & 11,2558 \\
\hline & & & 30 & 46,4712 & 6,8170 & 17,3084 & 13,4194 & 3,6632 & 13,0911 \\
\hline
\end{tabular}

As duas redes que produziram os melhores resultados também são compostas por três camadas escondidas iguais de 50 neurônios cada. Nesta abordagem, o número de atrasos TDNN das entradas é configurado como 2 e 10, respectivamente. As Figuras 4.16 e 4.17 apresentam os resultados das melhores topologias.

Figura 4.16 - Treinamento e Predição para $N_{1}=N_{2}=N_{3}=50$ e $n_{p}=n_{q}=2$.

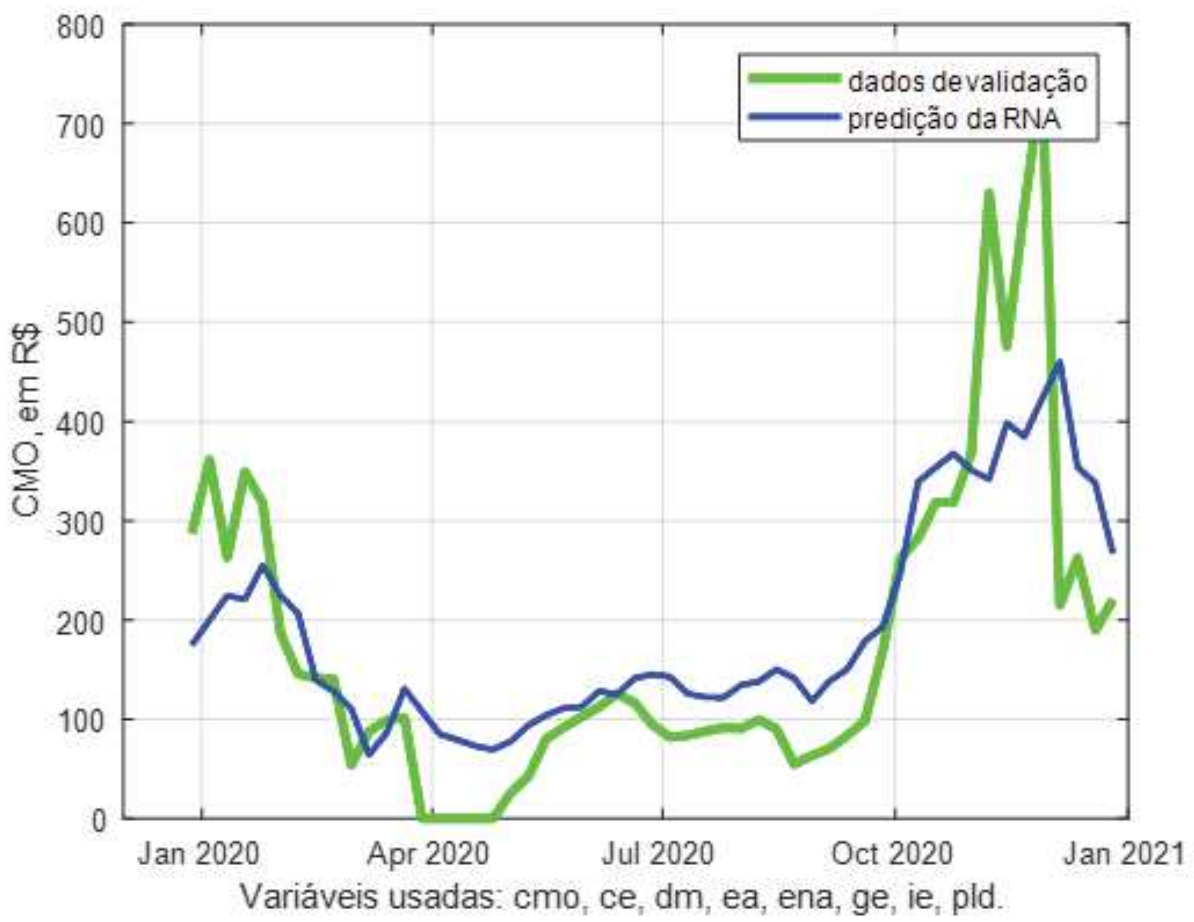


Figura 4.17 - Predição para $N_{1}=N_{2}=N_{3}=50$ e $n_{p}=n_{q}=10$.

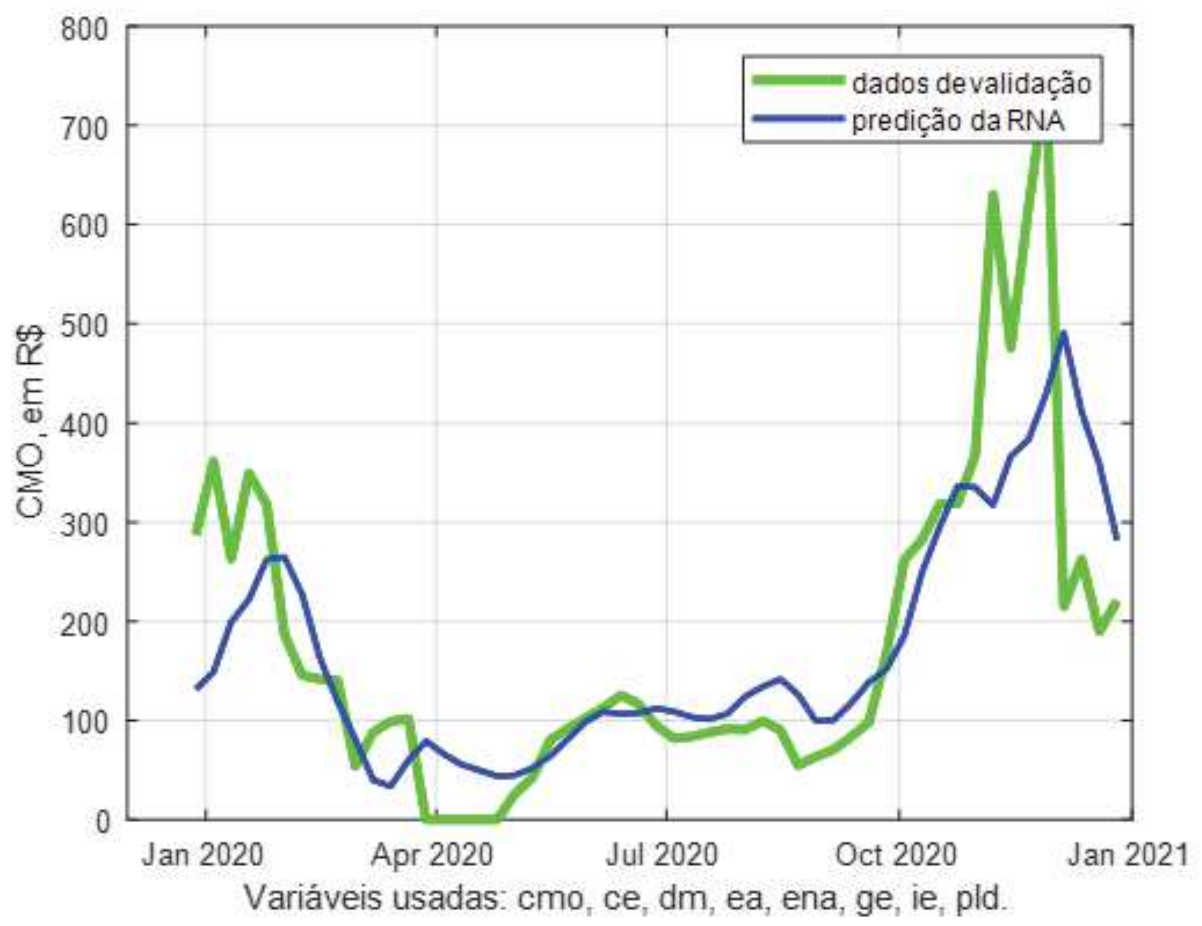

Verificou-se que os melhores resultados em cada conjunto de topologia foram obtidos utilizando todas as variáveis disponíveis (vide Figuras 4.11 e 4.12) como dados de entrada da rede, com atrasos $n_{p}$ e $n_{q}$ equivalentes a 10. É possível notar no gráfico apresentado pela Figura 4.12 que a partir do tamanho de janela 15, as variáveis IE e ENA têm um declínio na correlação com o CMO. O que justifica os erros de predição apresentarem os piores resultados quando utiliza-se os atrasos equivalentes a 30, independente do número de camadas e neurônios por camada.

Analisando de forma quantitativa os melhores resultados produzidos, tendo em vista a profundidade da rede, ou seja, o número de camadas escondidas, é possível notar que uma única camada é capaz de mapear a função o que vai de encontro ao Teorema da Aproximação Universal, derivado do Teorema de Andrey Kolmogorov (1957), que estabelece a capacidade de aproximação universal de funções para Redes Neurais Artificiais com apenas uma camada escondida e um número finito de neurônios (SILVA, 2010).

No entanto, para o mapeamento dos dados tratados nesta dissertação, o nível de abstração dos dados é grande, e assim os melhores resultados foram atingidos por intermédio de uma topologia com duas e três camadas escondidas. Conforme já citado, os dados são contaminados por ruídos, o que eleva a complexidade do problema, exigindo uma rede com mais capacidade de abstração. Foram realizados testes empíricos com redes com o número de camadas superior a três. Contudo estas não produziram bons resultados, por isso foram omitidas do presente trabalho. 
Complementarmente, comparando os resultados produzidos pela rede utilizando ou não as variáveis IE e ENA nota-se que elas possuem desempenho muito semelhante, conforme esperado. Uma vez que a correlação das variáveis com o CMO são muito próximas quando os janelamentos são limitados em até 30. A Tabela 4.5 mostra os melhores resultados de cada topologia, comparando a rede utilizando todas as variáveis como dados de entrada e excluindo as variáveis IE e ENA.

Tabela 4.5 - Comparação dos resultados utilizando ou não as variáveis IE e ENA

\begin{tabular}{|c|c|c|c|c|c|c|c|c|}
\hline $\begin{array}{l}\text { Dados de } \\
\text { Entrada }\end{array}$ & $N_{1}$ & $N_{2}$ & $N_{3}$ & $\begin{array}{c}n_{p} \mathbf{e} \\
n_{q}\end{array}$ & $\begin{array}{c}\text { Erro } \\
\text { Quadrático } \\
\text { Médio }(\mathbf{R} \$)^{2}\end{array}$ & $\begin{array}{l}\text { Erro } \\
\text { Médio } \\
(\mathbf{R} \$)\end{array}$ & $\begin{array}{l}\text { Desvio } \\
\text { Padrão }\end{array}$ & $\begin{array}{l}\text { Diferença } \\
\text { RMSE \% }\end{array}$ \\
\hline $\begin{array}{l}\text { CE, DM, EA, GE, } \\
\text { CMO e PLD }\end{array}$ & \multirow[t]{2}{*}{10} & \multirow[t]{2}{*}{ - } & \multirow[t]{2}{*}{ - } & 20 & 5,3162 & 2,3057 & 10,3329 & \multirow[t]{2}{*}{$3,41 \%$} \\
\hline $\begin{array}{l}\text { CE, DM, EA, GE, IE, } \\
\text { ENA, CMO e PLD }\end{array}$ & & & & 10 & 5,1350 & 2,2661 & 10,2821 & \\
\hline $\begin{array}{l}\text { CE, DM, EA, GE, } \\
\text { CMO e PLD }\end{array}$ & \multirow[t]{2}{*}{20} & \multirow[t]{2}{*}{20} & \multirow[t]{2}{*}{ - } & 20 & 5,1836 & 2,2767 & 10,3339 & \multirow[t]{2}{*}{$1,81 \%$} \\
\hline $\begin{array}{l}\text { CE, DM, EA, GE, IE, } \\
\text { ENA, CMO e PLD }\end{array}$ & & & & 10 & 5,0900 & 2,2561 & 10,2322 & \\
\hline $\begin{array}{l}\text { CE, DM, EA, GE, } \\
\text { CMO e PLD }\end{array}$ & \multirow[t]{2}{*}{10} & \multirow[t]{2}{*}{20} & \multirow[t]{2}{*}{15} & 20 & 5,5283 & 2,3512 & 10,4684 & \multirow[t]{2}{*}{$3,64 \%$} \\
\hline $\begin{array}{l}\text { CE, DM, EA, GE, IE, } \\
\text { ENA, CMO e PLD }\end{array}$ & & & & 10 & 5,3268 & 2,3080 & 10,3976 & \\
\hline $\begin{array}{l}\text { CE, DM, EA, GE, } \\
\text { CMO e PLD }\end{array}$ & \multirow[t]{2}{*}{50} & \multirow[t]{2}{*}{50} & \multirow[t]{2}{*}{50} & 20 & 4,9575 & 2,2265 & 10,1728 & \multirow[t]{2}{*}{$11,26 \%$} \\
\hline $\begin{array}{l}\text { CE, DM, EA, GE, IE, } \\
\text { ENA, CMO e PLD }\end{array}$ & & & & 2 & 4,3991 & 2,0947 & 9,8723 & \\
\hline
\end{tabular}

De maneira qualitativa, comparando as Figuras 4.14 e 4.15 com as Figuras 4.16 e 4.17 é possível verificar que a rede utilizando todas as entradas se destaca frente à rede que não utiliza as variáveis IE e ENA, sendo capaz de generalizar a tendência de dados de maneira mais fiel. A adição de informações de IE e ENA é benéfica.

\subsection{Filtragem da saída da Rede Neural}

Esta última abordagem objetiva analisar o desempenho do uso combinado das Redes Neurais com a aplicação de filtros em sua saída. Conforme mostrado nas seções anteriores, o comportamento dos dados preditos podem ter embutidos componentes com altas variações que, ao serem realimentadas podem amplificar os efeitos dos erros. Ao realimentar uma saída filtrada, pretende-se diminuir estas variações na predição, tornando-a mais suave.

Serão testadas as mesmas topologias de rede analisadas na seção 4.2 considerando todas as variáveis na entrada da rede e incorporando 4 tipos de filtragem na saída da RNA: Passa-baixa FIR, Passa-baixa IIR, Média-Móvel e Filtro de Kalman. Os parâmetros dos filtros foram configurados empiricamente, de modo que os que estão sendo utilizados são os que produziram os melhores resultados. 
Ao aplicar os diferentes filtros na saída da rede, obtiveram-se resultados superiores aos encontrados na seção 4.2. Sendo que os melhores e piores resultados são produzidos pelas mesmas topologias encontradas anteriormente. Entretanto, com a aplicação da filtragem o erro quantitativo produzido pela rede é menor ao produzido sem a filtragem. A Tabela 4.6 apresenta os resultados obtidos considerando todos os filtros aplicados e com $n_{p}=n_{q}=2$ e 10 . Vale ressaltar que a rede foi testada com 20 e 30 atrasos TDNN nos dados das entradas. Entretanto, os piores resultados foram produzidos pela rede com 30 atrasos, seguido da rede configurada com 20 atrasos.

Em relação ao número de atrasos da rede, de forma similar à rede sem filtro, os melhores resultados são produzidos com redes de 10 atrasos. No que diz respeito à profundidade da rede e número de neurônios, tem-se uma melhor eficácia na rede com três camadas escondidas com 50 neurônios cada, seguido da rede com duas camadas com 20 neurônios. A diferença percentual entre o erro quadrádico médio produzido pelo melhor resultado da rede com três e duas camadas é de 8,16\%. Sendo que a diferença é pouco significativa frente à elevação do desempenho computacional com a inserção de mais camadas. A Figura 4.18 apresenta de forma qualitativa uma comparação dos resultados obtidos com a rede filtrada e sem a aplicação do filtro para o melhor resultado obtido.

Figura 4.18 - Predição para $N_{1}=N_{2}=N_{3}=50$ e $n_{p}=n_{q}=2$.

(a) Rede sem filtro.

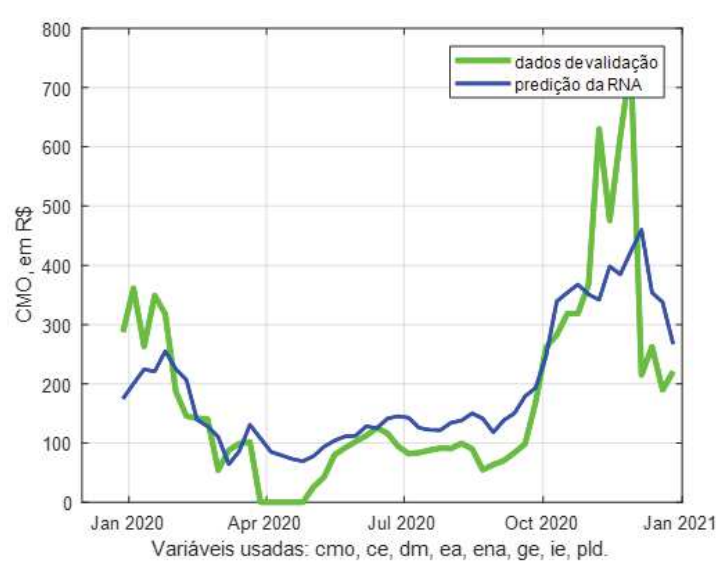

(b) Rede com filtro Passa Baixa IIR.

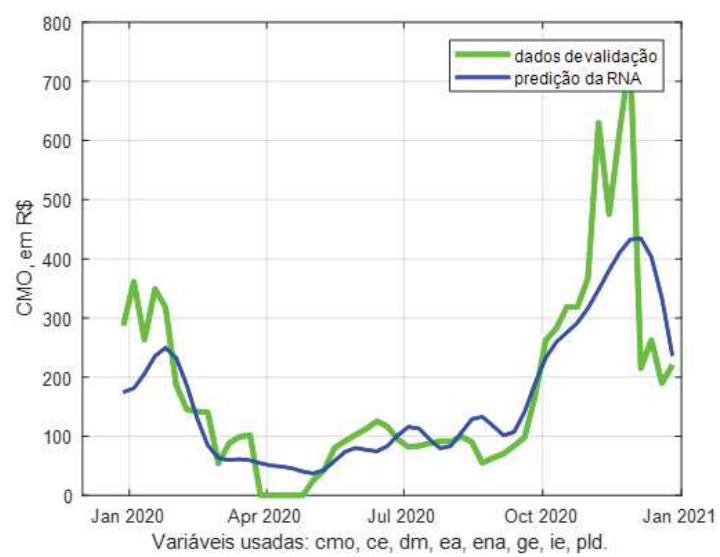

Nota-se que que as predições foram melhores com a aplicação do filtro na saída da rede, como dado pelo erro quadrático médio inferior. A predição é mais suave e representa melhor a dinâmica dos dados. O erro médio da predição reduziu 13,34\% e a correlação entre os valores preditos e reais aumentou significativamente. Desta forma, o processo de uso da filtragem na saída da rede colaborou para a redução do erro nas predições.

Com relação aos filtros, nota-se um desempenho superior para o filtro de médiamóvel, que apresentou melhores resultados em 75\% topologias testadas. A Figura 4.19 
Tabela 4.6 - Resultados por topologia (CE, DM, EA, GE, IE, ENA, CMO e PLD) - vários passos no futuro com filtragem (1 ano)

\begin{tabular}{|c|c|c|c|c|c|c|c|c|c|c|}
\hline \multicolumn{5}{|c|}{ Configuração da rede } & \multicolumn{3}{|c|}{ Treinamento } & \multicolumn{3}{|c|}{ Validação } \\
\hline$N_{1}$ & $N_{2}$ & $N_{3}$ & $\begin{array}{c}n_{p} \mathbf{e} \\
n_{q}\end{array}$ & Filtro & $\begin{array}{c}\text { Erro } \\
\text { Quadrático } \\
\text { Médio }(\mathrm{R} \$)^{2}\end{array}$ & $\begin{array}{l}\text { Erro } \\
\text { Médio } \\
(\mathbf{R} \$)\end{array}$ & $\begin{array}{l}\text { Desvio } \\
\text { Padrão }\end{array}$ & $\begin{array}{c}\text { Erro } \\
\text { Quadrático } \\
\text { Médio }(\mathbf{R} \$)^{2}\end{array}$ & $\begin{array}{c}\text { Erro } \\
\text { Médio } \\
(\mathrm{R} \$)\end{array}$ & $\begin{array}{l}\text { Desvio } \\
\text { Padrão }\end{array}$ \\
\hline \multirow{10}{*}{10} & \multirow{10}{*}{ - } & \multirow{10}{*}{ - } & \multirow{5}{*}{2} & Sem Filtro & 6,7917 & 2,6061 & 11,0053 & 8,4328 & 2,9039 & 10,5715 \\
\hline & & & & P-B FIR & 6,2909 & 2.5082 & 10.7968 & 7.6942 & 2.7738 & 10.3729 \\
\hline & & & & P-B IIR & 5,0955 & 2,2574 & 10,2139 & 7,4600 & 2,7313 & 10,3293 \\
\hline & & & & $\begin{array}{l}\text { Média } \\
\text { Móvel }\end{array}$ & 7,5359 & 2,7452 & 11,2965 & 7,2075 & 2,6847 & 10,1051 \\
\hline & & & & Kalman & 4,5049 & 2,1225 & 9,9333 & 8,4584 & 2,9083 & 10,6416 \\
\hline & & & \multirow{5}{*}{10} & Sem Filtro & 9,2775 & 3,0459 & 11,8477 & 5,1350 & 2,2661 & 10,2821 \\
\hline & & & & P-B FIR & 9.0186 & 3.0031 & 11,7664 & 4.8956 & 2,2126 & 10,1555 \\
\hline & & & & P-B IIR & 9,1560 & 3,0259 & 11,7774 & 4,6579 & 2,1582 & 10,0604 \\
\hline & & & & $\begin{array}{l}\text { Média } \\
\text { Móvel }\end{array}$ & 6,9835 & 2,6426 & 11,0223 & 4,2809 & 2,0690 & 9,8197 \\
\hline & & & & Kalman & 4,5590 & 2,1352 & 9,9038 & 4,9676 & 2,2288 & 10,2246 \\
\hline \multirow{10}{*}{20} & \multirow{10}{*}{20} & \multirow{10}{*}{ - } & \multirow{5}{*}{2} & Sem Filtro & 5,2171 & 2,2841 & 10,2585 & 6,1462 & 2,4791 & 10,2577 \\
\hline & & & & P-B FIR & 4,3604 & 2,0882 & 9,7894 & 6,0708 & 2,4639 & 10,0896 \\
\hline & & & & P-B IIR & 3,3368 & 1,8267 & 9,0095 & 4,1445 & 2,0358 & 9,5326 \\
\hline & & & & $\begin{array}{l}\text { Média } \\
\text { Móvel }\end{array}$ & 3,8963 & 1,9739 & 9,5053 & 5,2708 & 2,2958 & 9,7617 \\
\hline & & & & Kalman & 4,5147 & 2,1248 & 9,9236 & 6,2962 & 2,5092 & 10,4085 \\
\hline & & & \multirow{5}{*}{10} & Sem Filtro & 6,9043 & 2,6276 & 10,9604 & 5,0900 & 2,2561 & 10,2322 \\
\hline & & & & P-B FIR & 6,1209 & 2,4741 & 10,5998 & 4,7152 & 2,1715 & 10,0532 \\
\hline & & & & P-B IIR & 3,4973 & 3,0818 & 11,8541 & 4,6842 & 2,1643 & 10,0410 \\
\hline & & & & $\begin{array}{l}\text { Média } \\
\text { Móvel }\end{array}$ & 6,3512 & 2,5202 & 10,7533 & 4,1504 & 2,0372 & 9,7736 \\
\hline & & & & Kalman & 4,3554 & 2,0870 & 9,8024 & 4,9859 & 2,2329 & 10,2162 \\
\hline \multirow{10}{*}{10} & \multirow{10}{*}{20} & \multirow{10}{*}{15} & \multirow{5}{*}{2} & Sem Filtro & 4,5675 & 2,1372 & 9,9294 & 5,8822 & 2,4253 & 10,6371 \\
\hline & & & & P-B FIR & 3,7822 & 1,9448 & 9,4188 & 5,1149 & 2,2616 & 10,2946 \\
\hline & & & & P-B IIR & 4,5714 & 2,1381 & 9,8299 & 4,3735 & 2,0913 & 9,8797 \\
\hline & & & & $\begin{array}{l}\text { Média } \\
\text { Móvel }\end{array}$ & 4,2973 & 2,0730 & 9,7550 & 4,6559 & 2,1578 & 10,0492 \\
\hline & & & & Kalman & 4,2156 & 2,0532 & 9,7392 & 5,9377 & 2,4367 & 10,6790 \\
\hline & & & \multirow{5}{*}{10} & Sem Filtro & 4,9867 & 2,2331 & 9,9990 & 5,3268 & 2,3080 & 10,3976 \\
\hline & & & & P-B FIR & 7,3927 & 2,7190 & 11,1379 & 5,0175 & 2,2400 & 10,2479 \\
\hline & & & & P-B IIR & 7,4814 & 2,7353 & 11,1723 & 4,8768 & 2,2083 & 10,1494 \\
\hline & & & & $\begin{array}{l}\text { Média } \\
\text { Móvel }\end{array}$ & 7,5211 & 2,7425 & 11,1720 & 4,4923 & 2,1195 & 9,9706 \\
\hline & & & & Kalman & 4,4690 & 2,1140 & 9,8516 & 5,2062 & 2,2817 & 10,3293 \\
\hline \multirow{10}{*}{50} & \multirow{10}{*}{50} & \multirow{10}{*}{50} & \multirow{5}{*}{2} & Sem Filtro & 4,4300 & 2,1047 & 9,7030 & 4,3991 & 2,0947 & 9,8723 \\
\hline & & & & P-B FIR & 3,7646 & 1,9402 & 9,2286 & 4,2218 & 2,0547 & 9,7844 \\
\hline & & & & P-B IIR & 5,1286 & 2,2647 & 9,8733 & 3,8121 & 1,9524 & 9,5126 \\
\hline & & & & $\begin{array}{l}\text { Média } \\
\text { Móvel }\end{array}$ & 3,8103 & 1,9520 & 9,2946 & 3,9635 & 1,9908 & 9,6343 \\
\hline & & & & Kalman & 4,7633 & 2,1825 & 9,9462 & 4,5539 & 2,1340 & 9,9902 \\
\hline & & & \multirow{5}{*}{10} & Sem Filtro & 6,2309 & 2,4962 & 10,6137 & 4,8588 & 2,2043 & 10,1557 \\
\hline & & & & P-B FIR & 5,3023 & 2,3027 & 10,2408 & 4,5492 & 2,1329 & 9,9849 \\
\hline & & & & P-B IIR & 7,5574 & 2,7491 & 11,2259 & 4,4225 & 2,1029 & 9,9271 \\
\hline & & & & $\begin{array}{l}\text { Média } \\
\text { Móvel }\end{array}$ & 5,7025 & 2,3880 & 10,3990 & 3,9578 & 1,9894 & 9,6507 \\
\hline & & & & Kalman & 4,5997 & 2,1447 & 9,9129 & 4,8790 & 2,2088 & 10,1520 \\
\hline
\end{tabular}


apresenta uma comparação da predição produzida pela rede configurada com $N_{1}=N_{2}=20$ e $n_{p}=n_{q}=10$.

Figura 4.19 - Predição para $N_{1}=N_{2}=20$ e $n_{p}=n_{q}=10$.

(a) Filtro Média Móvel.

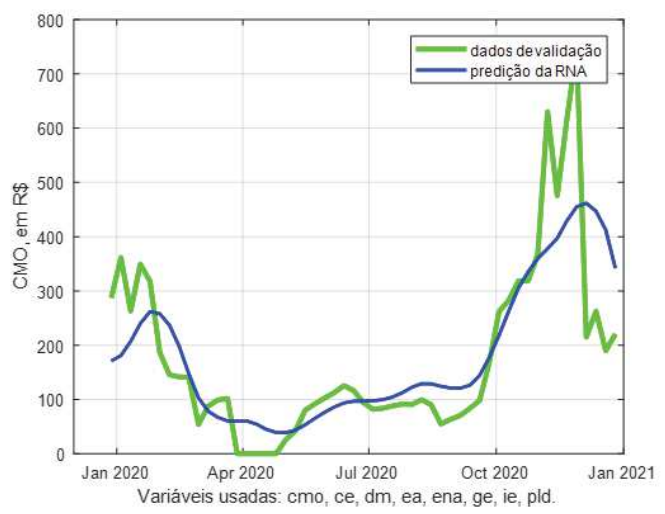

(c) Passa-Baixa FIR.

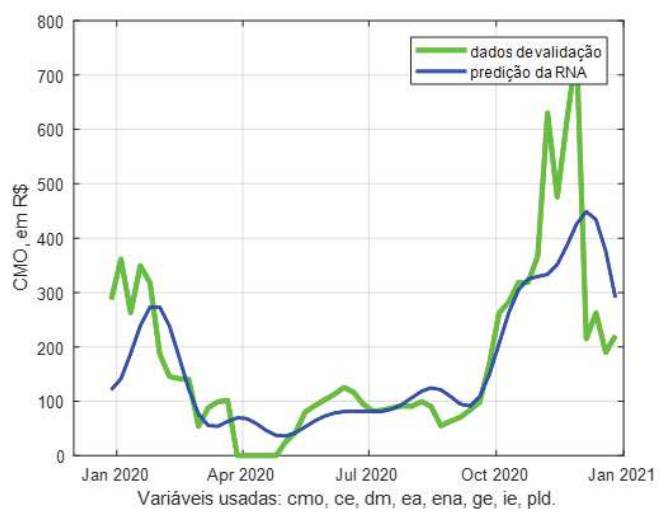

(b) Passa-Baixa IIR.

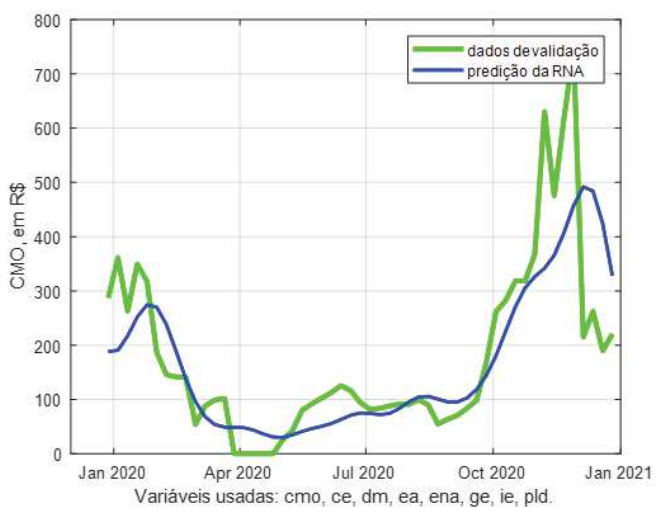

(d) Filtro de Kalman.

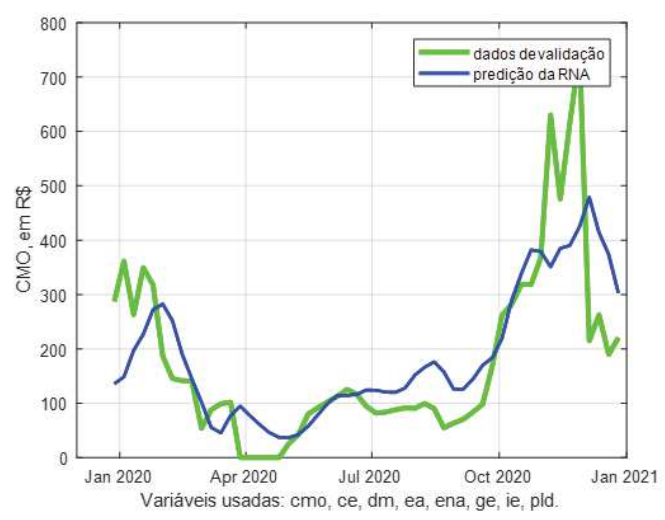

4.4 Conclusões sobre as análises dos resultados

A análise dos erros foi realizada de forma a investigar a influência de determinadas variáveis na predição do CMO, bem como avaliar o desempenho da rede recorrente com a aplicação de filtros em sua saída para a atenuação dos ruídos inerentes ao dados. A medida de acuracidade RMSE foi aplicada para que fosse possível mensurar as diferenças entre os dados preditos e os dados originais.

Dentre as abordagens analisadas, a análise de correlação das variáveis dos dados de entrada da rede com a variável a ser predita mostrou-se eficiente e acertada, permitindo um direcionamento na escolha dos melhores atrasos TDNN para a RNA. A inclusão de mais variáveis como dados de entrada melhorou o desempenho de predição.

Ressalta-se também que a inserção do filtro corretivo na saída da rede permitiu que a rede predissesse valores do CMO com maior acurácia. Embora houvessem diferenças 
entre os filtros aplicados, nota-se que as predições proporcionaram um ganho de eficiência nas predições, reduzindo as variações de alta frequência, minimizando a volatilidade dos dados e produzindo uma saída que acompanha eficientemente as tendências dos dados, proporcionando uma boa ferramenta de análise de longo prazo. 


\section{CONCLUSÕES}

Este trabalho mostrou uma abordagem baseada em Redes Neurais Artificiais aliada a filtragem estocástica para a obtenção da predição de uma variável importante no setor elétrico brasileiro, o Custo Marginal de Operação (CMO), associado à formação do Preço de Liquidação das Diferenças (PLD). O objetivo foi investigar uma maneira de se obter a predição de médio-longo prazo, de 1 ano a frente, semana a semana, para oferecer aos analistas da área de compra e venda de energia elétrica uma ferramenta que mostre a principal tendência dos preços da energia, facilitando o processo decisório no fechamento de contratos.

Este trabalho contou com uma metodologia exploratória advinda de estratégias na literatura, bem como a utilização de técnicas extras, de filtragem, em concomitância com a Rede Neural proposta. Primeiramente, este trabalho, utilizando a literatura, definiu a abordagem de aprendizado a ser utilizada, uma Rede Neural Artificial. Em seguida, diversos testes exploraram diferentes métodos de treinamento, com a escolha final pelo método ADAM (P.KINGMA; BA, 2014), por se tratar de um método de treinamento estatístico, excelente para dados estocásticos, caso da variável de interesse, o CMO.

A primeira prática consistiu em comparar a Rede Neural escolhida com os resultados de (NASCIMENTO et al., 2019), que faz a predição do PLD semanalmente. Em ambos os trabalhos, concluiu-se que para predições de médio-longo prazo (vários passos no futuro), a série temporal CMO/PLD não é suficiente, uma vez que se comporta de maneira parecida com uma variável aleatória em termos de correlação cruzada, não possuindo estruturas periódicas e, portanto, não oferecendo informação suficiente de aprendizado para a Rede Neural.

Assim, buscou-se a adição de novas informações para as entradas da Rede Neural por meio de variáveis explanatórias do Operador Nacional do Sistema Elétrico (ONS). Assim, diversas variáveis foram selecionadas e comparadas com a variável de interesse por meio de correlação. Este teste foi importante para determinar quais variáveis seriam mais importantes e, principalmente, a quantidade de entradas TDNN seriam escolhidas, prezando sempre pela alta correlação entre as variáveis de entrada e a variável predita.

Assim, testes da Rede Neural mostraram que a rede consegue, com estas novas variáveis de entrada, aprender os padrões de comportamento da variável de interesse. No entanto, como o CMO é uma variável com alta volatilidade, estes mesmo comportamento, ao ser realimentado na Rede Neural Recorrente, acumulava erros com o passar do tempo, oferecendo uma saída ruidosa.

Desta forma, adicionou-se uma abordagem de filtragem das saídas de Rede Neural Recorrente, de maneira a mitigar o problema da alta volatilidade dos dados preditos, melhorando a predição da rede, obtendo, portanto o bom acompanhamento das tendências 
da variável de interesse ao longo do ano. Exploraram-se os principais filtros disponíveis para a tarefa de eliminar contaminações e componentes de alta frequência do sinal. $\mathrm{O}$ resultado é uma predição suave, que acompanha a variável de interesse, oferecendo os principais momentos e comportamentos, auxiliando a tomada de decisões de compra e venda de energia.

\subsection{Propostas de desenvolvimentos futuros}

Seguindo a linha de pesquisa desenvolvida nesta dissertação e tendo em vista os resultados obtidos, algumas aplicações podem ser feitas com o intuito de aperfeiçoar o sistema apresentado. Os tópicos a seguir apresentam perspectivas no desenvolvimento de trabalhos futuros:

i Explorar um modelo híbrido, onde as variáveis de entrada da rede também sejam preditas para o caso de $\mathrm{n}$ passos no futuro;

ii Investigar a performance da rede implementada em outros mercados de energia, de forma a criar uma abordagem com maior capacidade de generalização;

iii Realizar uma análise de sensibilidade de forma a avaliar o desempenho do modelo assumindo as variáveis de entrada não preditas como sendo as do último ano do histórico;

iv Implementar a integração do sistema proposto com outras técnicas de inteligência artificial, como a lógica fuzzy, de tal maneira a capturar nuâncias dos dados, aumentando as informações disponíveis para a Rede Neural, tal qual diversas abordagens tem sido utilizadas nos mercados de ações (ZAVADZKI et al., 2020). 


\section{REFERÊNCIAS}

ACADEMY, D. S. Deep Learning Book. 2019. Disponível em <http://www. deeplearningbook.com.br>. Acessado em 09 mar. 2021.

ANEEL, A. N. de E. E. Mercado de Curto Prazo. 2021. Disponível em < https: / /www.aneel.gov.br/home?p_p_id $=101 \& p \_p \_l i f e c y c l e=0 \& p \_p \_s t a t e=$ maximized $\&$ $\mathrm{p} \_$_p_mode $=$view \&_101_struts_action $=\% 2$ Fasset_publisher $\% 2$ Fview_content $\&$ 101_returnToFullPageURL $=\% 2 F \&$ \& 101_assetEntryId $=15050759 \&$ _101_type $=$ content\&_101_groupId=656835\&_101_urlTitle=mercado-de-curto-prazo-mop\& inheritRedirect=true $>$. Acessado em 25 fev. 2021.

BRASIL. Lei no 9.074, de 7 de julho de 1995. 1995. Disponível em <http: //www.planalto.gov.br/ccivil_03/leis/19074cons.htm>. Acessado em 28 fev. 2021.

BRASIL. Decreto 2.335, de 6 de outubro de 1997. 1997. Disponível em <http: //www.planalto.gov.br/ccivil_03/decreto/d2335.HTM>. Acessado em 28 fev. 2021.

BRASIL. Lei 9.478, de 6 de agosto de 1997. 1997. Disponível em <http: //www.planalto.gov.br/ccivil_03/leis/19478.htm>. Acessado em 28 fev. 2021.

BRASIL. Medida Provisória 144, de 11 de dezembro de 2003. 2003. Disponível em <http://www.planalto.gov.br/ccivil_03/mpv/Antigas_2003/144.htm>. Acessado em 28 fev. 2021.

BRASIL. Medida Provisória 145, de 11 de dezembro de 2003. 2003. Disponível em <http://www.planalto.gov.br/ccivil_03/mpv/Antigas_2003/145.htm>. Acessado em 28 fev. 2021.

BRASIL. Decreto 5.081, de 14 de maio de 2004. 2004. Disponível em <http: //www.planalto.gov.br/ccivil_03/_ato2004-2006/2004/decreto/d5081.htm>. Acessado em 28 fev. 2021.

BRASIL. Decreto 5.163, de 30 de julho de 2004. 2004. Disponível em <http: //www.planalto.gov.br/ccivil_03/_ato2004-2006/2004/decreto/d5163.HTM>. Acessado em 28 fev. 2021.

BRASIL. Decreto 5.175, de 9 de agosto de 2004. 2004. Disponível em <http: //www.planalto.gov.br/ccivil_03/_ato2004-2006/2004/Decreto/D5175.htm>. Acessado em 28 fev. 2021.

BRASIL. Lei 10.847, de 15 de março de 2004. 2004. Disponível em <http: //www.planalto.gov.br/ccivil_03/_Ato2004-2006/2004/Lei/L10.847.htm>. Acessado em 28 fev. 2021.

BRASIL. Lei 10.848, de 15 de março de 2004. 2004. Disponível em <http: //www.planalto.gov.br/ccivil_03/_Ato2004-2006/2004/Lei/L10.848.htm>. Acessado em 28 fev. 2021.

CCEE, C. de Comercialização de E. E. Com quem relaciona. 2021. Disponível em $<$ https://www.ccee.org.br/portal/faces/pages_publico/onde-atuamos/com_quem_se_ relaciona?_afrLoop $=100800964117829 \&$ _adf.ctrl-state $=13006$ afo7p_1\#!\%40\%40\%3F 
afrLoop\%3D100800964117829\%26_adf.ctrl-state\%3D130o6afo7p_5>. Acessado em 28 fev. 2021.

CCEE, C. de Comercialização de E. E. Deck de Preços. 2021. Disponível em $<$ https://www.ccee.org.br/portal/faces/pages_publico/o-que-fazemos/como_ccee_ atua/precos/deck_de_precos?_afrLoop $=23998935792650 \&$ _adf.ctrl-state=1iiq7eugc 14\#!\%40\%40\%3F_afrLoop\%3D23998935792650\%26_adf.ctrl-state\%3D1iiq7eugc_18>. Acessado em 26 fev. 2021.

CCEE, C. de Comercialização de E. E. Metodologia. 2021. Disponível em <https:// www.ccee.org.br/portal/faces/pages_publico/o-que-fazemos/como_ccee_atua/precos/ metodologia_de_precos?_afrLoop=104858829549211\&_adf.ctrl-state=19bttq07jq_1\# !\%40\%40\%3F_afrLoop\%3D104858829549211\%26_adf.ctrl-state\%3D19bttq07jq_5>. Acessado em 02 mar. 2021.

CCEE, C. de Comercialização de E. E. Preços. 2021. Disponível em < https://www.ccee. org.br/portal/faces/oquefazemos_menu_lateral/precos? _afrLoop $=208972491694133 \&$ _adf.ctrl-state $=$ yklide4en_1\#!\%40\%40\%3F_afrLoop\%3D208972491694133\%26_adf. ctrl-state\%3Dyklide4en_5>. Acessado em 26 fev. 2021.

CCEE, C. de Comercialização de E. E. Quem participa. 2021. Disponível em $<$ https://www.ccee.org.br/portal/faces/pages_publico/quem-participa?_adf.ctrl-state= 6dms8ozk5_18\&_afrLoop=26108519444505\#!>. Acessado em 27 fev. 2021.

CCEE, C. de Comercialização de E. E. Setor Elétrico. 2021. Disponível em $<$ https://www.ccee.org.br/portal/faces/pages_publico/onde-atuamos/setor_eletrico? adf.ctrl-state $=$ wdsdnrt8i_1\&_afrLoop $=125894233318809 \# ! \% 40 \% 40 \% 3 \mathrm{~F} \_$afrLoop $\%$ 3D125894233318809\%26_adf.ctrl-state\%3Dwdsdnrt8i_5>. Acessado em 25 fev. 2021.

COELHO, I. Estudo sobre a aplicação de Redes Neurais Recorrentes para previsão da geração eólica e do Preço de Liquidação das Diferenças. [S.l.]: Monografia, UFSC, 2018.

DAMETTO, R. C. Estudo da aplicação de redes neurais artificiais para predição de séries temporais financeiras. [S.l.]: Dissertação, Unesp, 2018.

DUDA, R. O.; HART, P. E.; STORK, D. G. Pattern Classification. 2. ed. [S.1.]: Wiley-Interscience, 2000. v. 63.

FILHO, J. C. R. Previsão de multi-passos a frente do preço de energia elétrica de curto prazo no mercado brasileiro. Tese (Doutorado) — Universidade Federal do Pará, 2014.

HAGAN, M. T.; MENHAJ, M. B. Training feedforward networks with the Marquardt algorithm. IEEE transactions on Neural Networks, v. 5, n. 6, p. 989-993, 1994.

HAYKIN, S. Adaptive Filter Theory. [S.l.]: 2nd ed. Englewood Cliffs, N.J.: Prentice Hall, 1996.

HEBB, D. O. The Organization Of Behavior A Neuropsychological Theory. [S.l.]: John Wiley And Sons Inc New York, Chapman And Hall Limited London, 1949.

HOPFIELD, J. J. Neural networks and physical systems with emergent collective computational abilities. Proceedings of the national academy of sciences, v. 79, n. 8, p. 2554-2558, 1982. 
KAILATH, T. Linear Systems. [S.l.]: Englewood Cliffs, NJ: Prentice Hall, 1980.

KALMAN, R. E. A New Approach to Linear Filtering and PRediction Problemns. Transaction of the ASME - Journal of Basic Enginerring, pp. 35-45, 1960.

LEITE, A. L. da S. Causas da volatilidade do preço spot de eletricidade no Brasil. [S.l.]: Ensaios FEE, v. 34, p. 647-668-668, 2013.

MATHWORKS. Matlab. 2021. Disponível em < https://www.mathworks.com/products/ matlab.html>. Acessado em 02 mar. 2021.

MCCULLOCH, W. S.; PITTS, W. A logical calculus of the ideas immanent in nervous activity. The bulletin of mathematical biophysics. v. 5, n. 4, p. 115-133, 1943.

MEDIUM. Human in a Machine World. 2016. Disponível em < https://medium. com/human-in-a-machine-world/mae-and-rmse-which-metric-is-better-e60ac3bde13d $>$. Acessado em 13 mar. 2021.

MINSKY, M. L.; PAPERT, S. A. Perceptrons: an introduction to computational geometry. [S.l.]: MIT Press, Cambridge, Massachusetts, 1969.

NASCIMENTO, F. B. do. Redes Neurais Artificiais aplicadas à predição do Preço de Liquidação das Diferenças no Mercado de Energia. [S.l.]: Monografia, UFJF, 2017.

NASCIMENTO, F. B. do; OLIVI, L. R.; LIMA, L. H. L. Multi-step forecasting of the Brazilian Energy Market Price using Autoregressive Neural Networks. VII Simpósio Brasileiro de Sistemas Elétricos (SBSE2018), Niterói-RJ, 2018.

NASCIMENTO, F. B. do et al. Weekly forecast of the Settlement Price of Differences in the Brazilian short-term market through recurrent artificial neural networks. $14^{\circ}$ Simposio Brasileiro de Automação Inteligente, Ouro Preto, 2019.

ONS, O. N. do S. E. Histórico da Operação. 2020. Disponível em <http: //www.ons.org.br/Paginas/resultados-da-operacao/historico-da-operacao $>$. Acessado em 08 jun. 2020.

ONS, O. N. do S. E. Carga de Energia. 2021. Disponível em < http://www.ons.org.br/ Paginas/resultados-da-operacao/historico-da-operacao/carga_energia.aspx $>$. Acessado em 07 abr. 2021.

ONS, O. N. do S. E. Custo Marginal de Operação. 2021. Disponível em <http: //www.ons.org.br/Paginas/resultados-da-operacao/historico-da-operacao/cmo.aspx>. Acessado em 07 abr. 2021.

ONS, O. N. do S. E. Demanda Máxima. 2021. Disponível em <http://www.ons.org. br/Paginas/resultados-da-operacao/historico-da-operacao/demanda_maxima.aspx $>$. Acessado em 07 abr. 2021.

ONS, O. N. do S. E. Energia Armazenada. 2021. Disponível em < http://www.ons.org. br/Paginas/resultados-da-operacao/historico-da-operacao/energia_armazenada.aspx>. Acessado em 07 abr. 2021.

ONS, O. N. do S. E. Energia Natural Afluente. 2021. Disponível em < http: //www.ons.org.br/Paginas/resultados-da-operacao/historico-da-operacao/energia_ afluente_subsistema.aspx>. Acessado em 07 abr. 2021. 
ONS, O. N. do S. E. Geração de Energia. 2021. Disponível em <http://www.ons.org.br/ Paginas/resultados-da-operacao/historico-da-operacao/geracao_energia.aspx $>$. Acessado em 07 abr. 2021.

ONS, O. N. do S. E. Intercâmbios de Energia. 2021. Disponível em < http://www.ons.org. $\mathrm{br} /$ Paginas/resultados-da-operacao/historico-da-operacao/intercambios_energia.aspx $>$. Acessado em 07 abr. 2021.

P.KINGMA, D.; BA, J. Adam: A method for stochastic optimization. arXiv preprint arXiv:1412.6980, 2014.

RIEDMILLER, M.; BRAUN, H. A direct adaptive method for faster backpropagation learning: The RPROP algorithm. IEEE international conference on neural networks. $p$. 586-591., 1993.

RODRIGUES, A. L. Redes Neurais Artificiais aplicadas na previsão de preços do mercado spot de energia elétrica. [S.1.]: Dissertação, USP, 2009.

ROSENBLATT, F. Principles of neurodynamics. perceptrons and the theory of brain mechanisms. [S.l.]: Cornell Aeronautical Lab Inc Buffalo NY, 1961.

RUMElHART, G. E. H. D. E.; WILliAnS, R. J. Parallel Distributed Processing. [S.l.]: MT Press, Vol.1, 1986.

SILVA, D. H. S. e. R. A. F. Ivan Nunes da. Redes Neurais Artificiais: para engenharia e ciências aplicadas. [S.1.]: Editora Artliber, 2010.

SMITH, S. W. The Scientist and Engineer's Guide to Digital Signal Processing. [S.1.]: 2nd ed. California Technical Publishing San Diego, California, 1999.

SOUZA, A. J. S. de. Análise e Previsão da volatilidade do preço de liquidação das diferenças no mercado brasileiro utilizando o modelo GARCH. [S.l.]: Dissertação, UFBA, 2013.

SOUZA, F. C. Dinâmica Da Gestão De Riscos No Ambiente De Contratação Regulada No Setor Elétrico Brasileiro. Tese (Doutorado) - Universidade Federal Do Rio De Janeiro, 2008 .

WIDROW, B. Generalization and information storage in network of Adaline 'neurons'. Self-organizing systems-1962, 1962.

ZAVADZKI, S. et al. Computational Intelligence Techniques Used for Stock Market Prediction: A Systematic Review. IEEE Latin America Transactions, v. 18, n. 04, p. 744-755, 2020. 